UNIVERSIDADE DE SÃO PAULO

FACULDADE DE ODONTOLOGIA

\title{
A COMPREENSÃO DOS PESQUISADORES \\ DA ODONTOLOGIA SOBRE ÉTICA EM \\ PESQUISA COM SERES HUMANOS
}

\section{LUCIANA MARIA CAVALCANTE MELO}

Dissertação apresentada à Faculdade de Odontologia da Universidade de São Paulo, para obter o Título de Mestre, pelo Programa de Pós-Graduação em Odontologia. Área de Concentração: Deontologia e Odontologia Legal.

São Paulo 2002 
Data da Defesa: 16/01/2003

\section{Banca Examinadora}

Prof. Dr. Dalton Luiz de Paula Ramos

Julgamento: Aprovada Assinatura:

Prof. Dr. José Leopoldo Ferreira Antunes

Julgamento: Aprovada Assinatura:

Prof. Dr. Bader Buriham Saraiva

Julgamento: Aprovada Assinatura: 
UNIVERSIDADE DE SÃO PAULO

FACULDADE DE ODONTOLOGIA

\section{A COMPREENSÃO DOS PESQUISADORES \\ DA ODONTOLOGIA SOBRE ÉTICA EM \\ PESQUISA COM SERES HUMANOS}

\section{LUCIANA MARIA CAVALCANTE MELO}

Dissertação apresentada à Faculdade de Odontologia da Universidade de São Paulo, para obter o Título de Mestre, pelo Programa de Pós-Graduação em Odontologia. Área de Concentração: Deontologia e Odontologia Legal.

Orientador:

Prof. Dr. Dalton Luiz de Paula Ramos

São Paulo 
Ando devagar porque já tive pressa e levo esse sorriso, porque jáchorei de mais Hoje me sinto mais forte, mais feliz quem sabe eu só levo a certeza de que muito pouco eu sei, eu nada sei

Conhecer as manhãs e as manthas, o sabor das massas e das maçãs, é preciso o amor pra poder pulsar, é preciso paz pra poder sorrir, é preciso a chuva para florir.

Penso que cumprir a vida seja simplesmente compreender a marcha, e ir tocando em frente como um veltho boiade iro levando a boiada, eu vou tocando os dias pela longa estrada eu vou, de estrada eu sou

Todo mundo ama um dia todo mundo chora, Um dia a gente chora, no outro vai embora

Cada um de nós compõe a sua fistória, e cada ser em si, carrega o dom de ser capaz, e serfeliz

Ando devagar porque já tive pressa e levo esse sorriso porque já chorei de mais Cada um de nós compõe a sua história, e cada ser em si, carrega o dom de ser capaz, e ser feliz. 
"O avanço em busca do confecimento leva ao crescimento profundo das causas explícitas e abstratas que refletem na crença daquela teoria que se quer formular. A ética é a forma delicada e essencial na aplicação dos conceitos teóricos e na valorização e respeito ao outro.

Ser ético é saber cada limite em toda área que se quer atuar. Daí a importância que se deve dar as diferenças.

Deus em sua plenitude é Ser ético. Ele sabe o momento certo de levar sua palavra a cada ser fumano."

Maria Lúcia Cavalcante Lima, 
$\mathcal{A}$ Deus por iluminar cada

passo do me u caminfir.

$\dot{\mathcal{A}}$ você, minha que rida mãezinha:

Por toda compreensão, carinfo, respeito e

ilimitado Amor.

Dos momentos difice is aos de alegria, compartilha comigo minha vida; minha história.

Hoje, essa fistória também é sua. Você é minha grande fonte de exemplo e de amor!

À Liza, minha irmã, que mesmo distante,

sinto seu amor e energia; hoje e por toda

minha vida! Você é minha luz!

Para o meu irmão gúnior, por todo o

carinho e torcida. 
Ao meu presente que veio junto ao mestrado, Meu Amor: Luis! Por toda de dic ação, paciência e companheirismo nos momentos de euforia e de cansaço! Minha alegria é também resultado da sua presença em minha vida! Ulm grande Encontro!

$\mathcal{D E D I C O} \mathcal{E S} \mathcal{T} \mathcal{E} \mathcal{T} R \mathcal{A B A} \mathcal{L} \mathcal{H} O$ 
Ao meu orientador, Prof. Dr. Dalton Luiz de Paula Ramos, pelo incentivo, pela paciência frente a minha ansiedade e por acreditar no meu sonho fazendo junto, uma realidade! 
Ao Prof. Dr. José Leopoldo Ferreira Antunes, pelo imenso carinho e atenção dedicada; orgulho-me de ter conhecido este ser humano íntegro, capaz e amigo.

À Prof . Elaine Gomes dos Reis, minha amiga e "orientadora informal", por tudo que aprendi com sua história e experiência; acima de tudo, seu "colo" e ensinamentos foram fundamentais para a realização deste trabalho. Sou sua fã!

À Prof ${ }^{a}$. Dr ${ }^{\mathrm{a}}$. Bader Sawaia, pelos apontamentos importantes que colaboraram para minha interminável reflexão; e por participar carinhosamente deste meu grande momento.

À Prof. ${ }^{a}$ Dra . Hilda Ferreira Cardozo, pela alegria, força e pelas cores que acrescentou na tela da minha Vida; pela cumplicidade e carinho que nos uniu em laços para além do universo acadêmico; "minha mãezinha!"

À Prof ${ }^{a}$. Dr ${ }^{a}$. Ida Tecla Prellwitz Calvielli, pelos ensinamentos e compreensão dos nossos limites; e por estar sempre junto com palavras de carinho e incentivo.

Aos docentes do Departamento de Odontologia Social: Moacyir, Maria Ercilia, Edgar, Rogério, Toninho, Simone e Rodolfo pelo apoio e atenção que sempre dispensaram.

À minha amiga Aiko, que dispensou sua atenção, seu carinho e apoio nos momentos de desespero e necessidade; sou eternamente grata!

Aos meus AMIGOS de Mestrado: Tati, companheira eterna!; Ulissão e Fábio, meus irmãos!; Luis Fernando, o carinhoso; Rey, o contador de histórias; Evelyn e Muti, nosso dia a dia!; Nilcéia, Solange e Aiko, as conselheiras-mães; Vítor e Plínio, são irmãos?!; Sara, a palavra certa; Léo, o paizão!; Márcio, o cavalheiro; Rodrigo, o mineirinho; Julie e Cecília, as guerreiras!; Regina, a auditora!; Fernando e Cilene, companheiros de orientação; Lu, meu namorado! O meu carinho e alegria para todos vocês!

Às funcionárias da secretaria do Departamento de Odontologia Social: Marieta, Sônia, Andréia e Laura, em cada uma, encontrei apoio, paciência, carinho e laços de amizade! Um grande beijo... com muita alegria!

Aos funcionários do Serviço de Documentação Odontológica que sempre estavam àdisposição para nos auxiliar. Luzia e Cidinha, meu carinho especial. 
Ao Prof. Dr. Joel Bianchi (in memoriam), primeiro incentivador que me mostrou o caminho; estar lá no céu sorrindo e dizendo: "O dia está lindo hoje!". Sua maneira de olhar à vida com simplicidade foi uma lição que estou aprendendo até hoje.

Ao Prof. Dr. Antonio Carlos Bombana, pelo estímulo e apoio no momento certo.

À Evelin Regina de Freitas Triviño, pelo incentivo, carinho e compreensão nos momentos de ausência na Clínica Odontológica; sua força e amizade foram essenciais na manutenção da minha "tranqüilidade" para estudar.

À Fabiane, Irany, Lourdinha e todos os meus amigos da Clínica Odontológica, que compreenderam "minha loucura" e me ajudaram, cada um da sua maneira, a sentir-me mais forte e mais feliz. Grandes Companheiros!

À Maria do Carmo Bottino, que acreditou em mim desde o início! Meu carinho e gratidão estarão sempre reservados a você.

À Marta, minha amiga e profissional que admiro! Agradeço pela revisão deste trabalho, além de todo carinho dedicado.

Às minhas tias: Cléo, Líbia, Leone e Telma; grandes mulheres e eternas incentivadoras do meu caminhar! Amo vocês!

Às amigas Rôsangela, Samira, Regina, Cristiane, Cristina, Carolina, Juliana, Roberta e Daniele que estiveram ao meu lado sempre que preciso, compartilhando imensa alegria; compreendendo minha ausência quando foi preciso estudar.

Aos meus primos: Gilda, Alexandre e Dani, que carinhosamente me acolheram com amor e transmitiram o carinho familiar que, muitas vezes foi tão necessário.

Aos sujeitos desta pesquisa, pesquisadores da Odontologia, que, com suas palavras e sentimentos ajudaram-me a construir a essência deste trabalho. 
$\mathcal{N}$ ão basta que seja pura e justa a nossa causa; é necessário que a pureza e a justiça existam dentro de nós. (Autor desconfecido) 


\section{SUMÁRIO}

p.

LISTA DE FIGURAS

LISTA DE TABELAS

LISTA DE ABREVIATURAS E SIGLAS

RESUMO

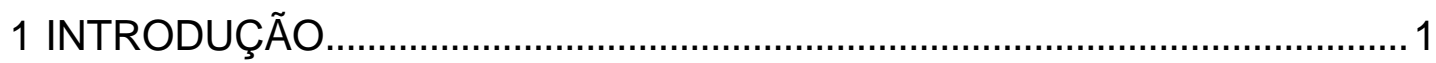

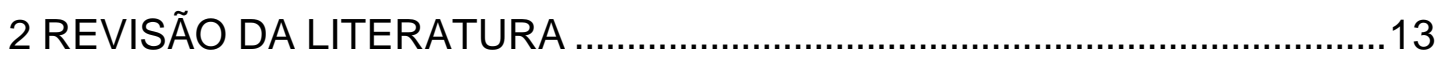

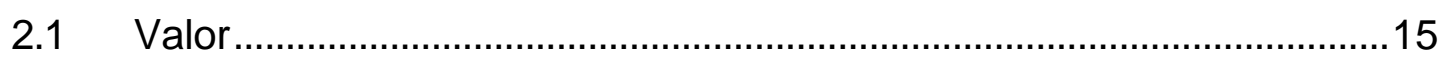

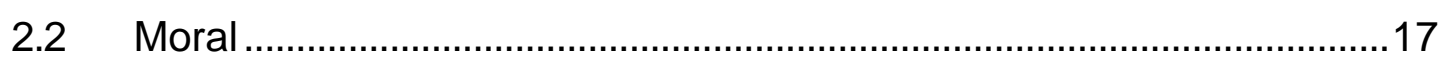

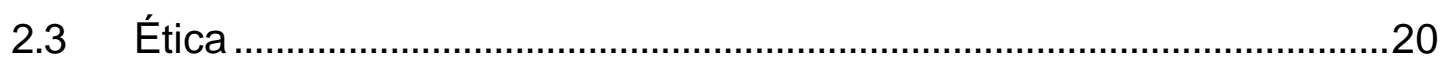

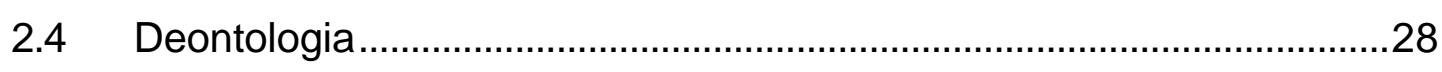

2.5 Experimentação em seres humanos ..................................................33

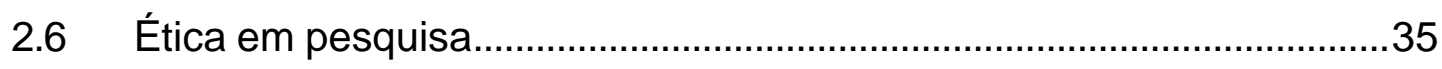

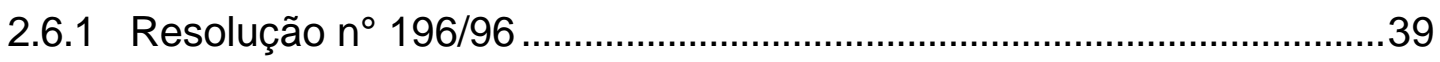

2.6.2 Comitê de Ética em Pesquisa............................................................. 41

2.7 A Bioética: princípios e fundamentos .................................................42

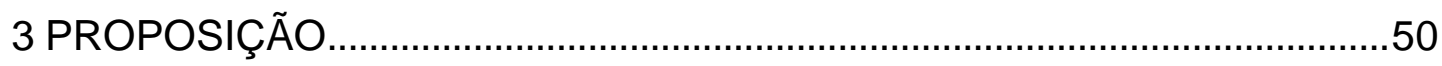

4 MATERIAL E MÉTODO …........................................................................ 51

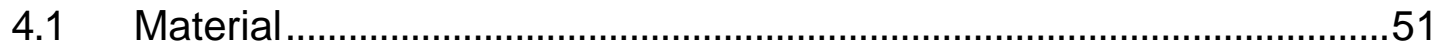

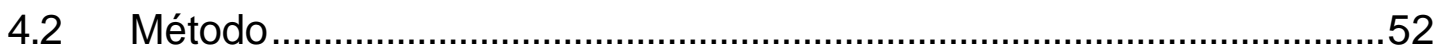




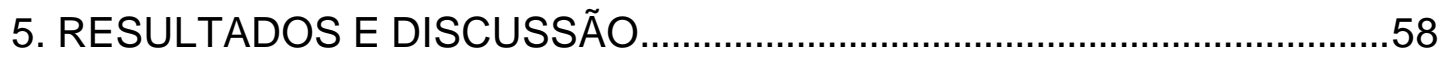

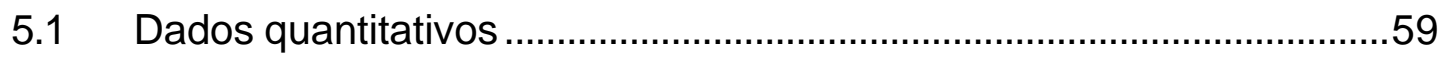

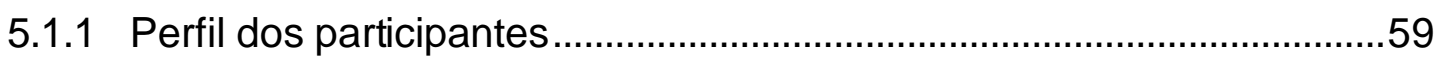

5.1.2 Utilização dos instrumentais questionários e/ou entrevistas nas

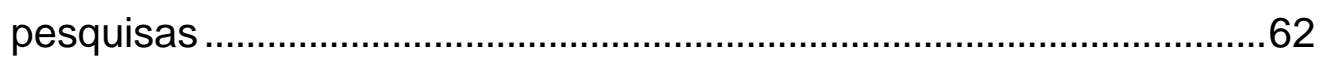

5.1.3 Perfil do público envolvido nas pesquisas ………………………….......63

5.1.4 Apreciação dos projetos de pesquisa..................................................70

5.1.5 Conhecimento da Resolução № 196/96 ………………………….......70

5.1.6 Participação em eventos sobre Ética em Pesquisa .................................71

5.2 Dados qualitativos....................................................................................

5.2.1 Pesquisa envolvendo seres humanos ..................................................

5.2.2 Processo de envolvimento do sujeito nas pesquisas ............................75

5.2.3 Abordagem com questionário e/ou entrevistas.......................................83

5.2.4 Situações de "riscos" na aplicação de questionários e / ou

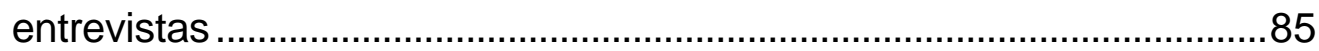

5.2.5 O significado de trabalhar com grupos institucionalizados ...................91

5.2.6 Importância da Resolução n 196/96 para as pesquisas .......................96

5.2.7 Os Comitês de Ética em Pesquisa - CEPs..........................................101

5.2.8 O que é Ética em Pesquisa? .................................................................105

6 CONSIDERAÇÕES FINAIS .....................................................................112

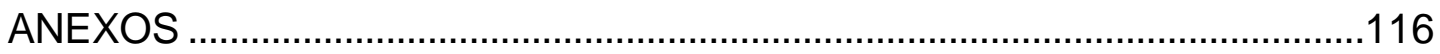

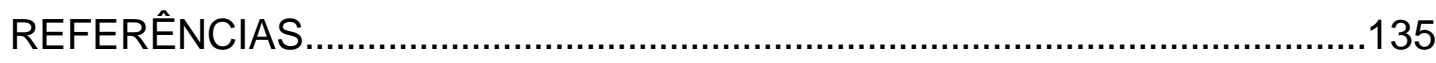

SUMMARY 


\section{LISTA DE FIGURAS}

Gráfico 5.1 - Distribuição por faixa etária e sexo (em no . absoluto). 60

Gráfico 5.2 - Participantes com experiência em pesquisa que exercem atividade de docência .60

Gráfico 5.3 - Representação dos participantes por Departamentos................61 


\section{LISTA DE TABELAS}

Tabela 5.1 - Público envolvido nas pesquisas dos participantes .64

Tabela 5.2 - Percepção dos participantes quanto às condições socieconômicas dos sujeitos de pesquisa.................................67

Tabela 5.3 - Percepção dos participantes quanto àescolaridade dos sujeitos de pesquisa... 


\section{LISTA DE ABREVIATURAS E SIGLAS}
A Alta
a.C. Antes de Cristo
AIDS Síndrome da imunodeficiência adquirida
Art. Artigo
BI Baixa Inferior
BS Baixa Superior
cap. Capítulo
CEP Comitê de Ética em Pesquisa
CICT Comissão Intersetorial de Ciência e Tecnologia
CIOMS Conselho para Organizações Internacionais de Ciências Médicas
CNS Conselho Nacional de Saúde
CONEP Conselho Nacional de Ética em Pesquisa
DNA Ácido Desoxirribonucléico
FOUSP Faculdade de Odontologia da Universidade de São Paulo
IAB International Association of Bioethics
IBGE Instituto Brasileiro de Geografia e Estatística
M Média
MI Média Inferior 
MS Média Superior

MS Ministério da Saúde

OMS Organização Mundial de Saúde

P Participante

p. Página

séc. Século

USP Universidade de São Paulo 


\section{RESUMO}

\section{A COMPREENSÃO DOS PESQUISADORES DA ODONTOLOGIA SOBRE ÉTICA EM PESQUISA COM SERES HUMANOS}

O olhar sobre o ser humano é primordial na história da reflexão ética em pesquisa. Alguns episódios de abusos em experimentação com seres humanos em todo o mundo sugeriram organizações mais eficazes do Estado e da sociedade em geral no controle e orientações éticas nas pesquisas; muitos autores associaram esse episódio ao nascimento da Bioética. No Brasil, o marco sobre essa reflexão e orientação está na aprovação da Resolução nº.196/96. A partir daí são instaurados os Comitês de Ética em Pesquisa (CEPs) e as pesquisas com seres humanos são amplamente discutidas e refletidas no âmbito institucional. Este estudo fundamenta-se na identificação e análise do discurso do pesquisador da Odontologia sobre ética em pesquisa, concepção de sujeito de pesquisa e utilização de questionários e / ou entrevistas. Foi empregado o método qualitativo de pesquisa, utilizando a técnica de Análise de Conteúdo como instrumento mediador para interpretação dos discursos. Foram entrevistados 28 pesquisadores seguindo um roteiro de questões que auxiliou no processo de diálogo entre entrevistador e participante. Com base nestas análises 
considera-se que: 1- Nas pesquisas da odontologia usualmente são envolvidos pacientes de Instituição de Ensino Superior; pessoas caracterizadas por condições socioeconômica baixa e de baixa escolaridade. 2- Identifica-se um distanciamento social, profissional e pessoal do pesquisador para com o sujeito de pesquisa. 3- O pesquisador concebe a Resolução oํ196/96 em diferentes papéis: o regulador, o educativo e o restritivo. 4- O conhecimento desta normativa brasileira é fundamental para auxiliar o pesquisador na avaliação e conduta ética de suas pesquisas. 5Para uma maior compreensão mútua, entre pesquisador e CEP, é necessário um esforço bilateral de aproximação. 6- O uso das técnicas, questionários e entrevistas é freqüentemente compreendido como método que não ocasiona risco ao sujeito participante. É necessário avaliar os riscos, do físico ao espiritual, em qualquer pesquisa que envolva seres humanos. 7- A compreensão de ética em pesquisa é determinada pelo contexto social que o pesquisador está situado; sua visão sobre ética está associada com o entendimento que se tem sobre o mundo, a sociedade, o homem e os valores. 


\section{INTRODUÇÃO}

Desde a antiga Grécia, a Ética é tema de bastante discussão e indispensável para a compreensão do comportamento humano em sociedade.

Nos tempos pré-históricos já havia uma necessidade de grupos humanos organizarem a vida e suas relações, surgindo formas de agir e de se comportar de acordo com a natureza daquele povo; essas formas expressavam a cultura, os valores, o conhecimento e suas crenças que eram ditas sob comunicação verbal: as grandes oratórias.

No entanto, foi surgindo a necessidade de registrar os modelos de comportamento como os códigos morais. Entre 1792 e 1750 a.C. surge o código de Hammourabi, na Babilônia, que designava o rei como formulador de leis e preservador da boa justiça. Os Livros de Manu surgem dez séculos a. C., e apresentava os preceitos da vida política, social e religiosa da filosofia budista (Caggiano, 2002).

"Esta moralidade primitiva surgia pragmaticamente como fruto da necessidade de organização social, por fim impostos sobre a população na forma de leis por parte de um soberano ou uma aristocracia, e como fruto de crendices e especulações religiosas. Não 
havia, portanto, nenhum esforço concreto no sentido de pensar abstrata e racionalmente o comportamento dos indivíduos e as relações sociopolíticas" (Gouvêa, 2002, p.14).

Os códigos foram tornando-se realidade nos mais variados povos da civilização antiga, como na China, Egito e Israel; e todos esses escritos estavam intrinsecamente unidos com as crenças e práticas cultuais e religiosas.

Por outro lado, deve-se à Ética contemporânea a origem do pensamento grego, com Sócrates, Platão, Aristóteles e seus discípulos. O olhar sobre o ser humano é ênfase primordial neste momento da história. Compreender o homem, suas inquietações e seus sentimentos são fortes bandeiras de reflexão e diálogo. É a era da Filosofia Clássica.

Segundo Gouvêa (2002), o "pai" da Ética deveria ser Platão. Justifica dizendo que todas as religiões são baseadas no "platonismo", e dá primazia àidéia do bem como fonte de todo o pensamento humano. Além de Platão, a base da reflexão ética ocidental está na filosofia de Aristóteles que contempla a virtude como a "perfeição da condição humana".

Na filosofia de Aristotéles, Gouvêa (2002, p.15) apresenta as considerações essenciais para a Ética:

"O comportamento eticamente adequado e feliz é fruto (....) do aperfeiçoamento intelectual do indivíduo, e as principais virtudes advindas deste desenvolvimento são a justiça, a prudência, a coragem e a moderação". 
Acompanhando este processo, o conhecimento da Ética, encontra-se o pensamento cristão como fonte basilar da conduta do homem na história. A reflexão cristã também é norteada pela cultura greco-romana e the é atribuído os fundamentos para compreensão da Ética, como: a noção de criação, de mandamento divino, a noção de pecado e a idéia de amor sacrificial. Além das três virtudes trazidas no Novo Testamento, que são a fé, a esperança e o amor.

O contexto da religião é associado ao caminho da Ética; os seus fundamentos são semelhantes e originam da pessoa, da relação (amor) e do comportamento (mandamento, fé). A ética cristã consiste na prática das virtudes.

"A cultura da humanidade parece constituir-se de três eixos fenomenológicos como pressupostos arquétipos da ética: a visão cosmocêntrica, em que o universo é o centro das preocupações; a visão teocêntrica, na qual o centro é o deus criador, interditor, sensor, prometente; e a visão antropocêntrica, em que o pólo é o próprio homem" (Marcos, 1999, p. 61).

Da antigüidade à modernidade vinculam-se papéis ao homem para conviver em sociedade; a liberdade, o respeito e fazer o bem fazem parte da natureza humana até hoje, na atualidade.

No tempo moderno surgem vários pensadores que contribuem para a reflexão ética; dentre eles, destacam-se Kant e Hegel. A filosofia de Kant apresenta uma proposta ética inteiramente racional onde o que é primordial 
é a livre escolha (Cohen \& Segre, 1995); este é ainda um modelo hegemônico na atualidade.

São vários os interlocutores da construção de uma "nova Ética". Em cada momento caracterizam-se elementos de identidade de um povo, de uma sociedade, de uma cultura; e porque não dizer, da dignidade humana. Este parece ser o preceito fundamental da Ética.

Etimologicamente, a palavra Ética origina-se do grego éthos e tem dois sentidos: o que significa MORADA, onde alguns autores relatam ser a Ética "a morada do ser"; e o segundo sentido quer dizer CARÁTER, ou seja, "modo de ser adquirido" (Marcos, 1999, p.76).

O espaço da ética na vida humana é naturalmente localizado no campo dos valores. Encontra-se na Filosofia a matéria mestra para a compreensão e estudo da Ética, Moral e dos Valores.

Compreende-se Ética sob a lógica de ser uma categoria particular do pensamento humano e que, como tal, procede de um exercício intelectual intrínseco ao processo interno de opções e escolhas valorativas.

"Ser ético é coisa de filósofo!". Esta afirmação, muitas vezes repetida, pode ser uma "meia" verdade a partir do momento que se mostra a história da ética na humanidade. É do ser humano a característica inata de questionar os fatos, as razões e os sentimentos; e quem é que não elabora questões acerca do mundo, da vida, da sociedade? Além do Filósofo, todas as pessoas; portanto, como diz Hossne (2001a, p.3), "se todos nós somos filósofos, a Ética é de fato 'coisa de todos nós, filósofos". 
Esta questão surge da eminente reflexão no campo da saúde sobre de quem é a Ética? A que se destina?

Os profissionais de saúde são pessoas que lidam diariamente com dilemas éticos, pois encontram no universo de suas ações questões internas e externas que os levam a fazer escolhas; essas opções são justamente baseadas no âmbito da vida e da particularidade da vida de outras pessoas. Encontra-se aí o grande dilema! "O que devo fazer quando a vida do outro está em minhas mãos?" Ou seja, "quais serão as conseqüências da minha ação sobre esse indivíduo?"

Naturalmente a resposta a essa pergunta, como também a outras, será norteada pelos princípios que o profissional está se guiando na sua prática profissional, aqui concebida como não dissociada da vida particular. Seguindo esta compreensão o profissional poderá escolher em fazer o bem; e esta opção Ihe dará fundamentos para justificar sua ação. Este é o encontro com a Bioética.

O termo Bioética nasce em meados de 1962 quando foi publicado um artigo na revista Life denominado ELES DECIDEM QUEM VIVE E QUEM MORRE, de acordo com Pessini \& Barchifontaine (1996), um dilema ético era apresentado: Um comitê em Seatle, nos Estados Unidos, abriu vagas para um programa de hemodiálise na cidade. Muitas pessoas procuraram 0 serviço e não havia possibilidade de atender a todos; a opção foi consultar um grupo que decidisse sobre quais seriam os privilegiados. Este fato sugeriu reflexões éticas que muitos associaram ao nascimento da Bioética. 
A Bioética ganha maior expressão a partir da publicação do livro Bioethics: bridge to the future do biólogo e oncologista Van Ressenlaer Potter em 1971. Este autor definiu Bioética como a necessidade de ajuste entre a humanidade e o universo/meio ambiente. Aspirava-se uma disciplina que houvesse relação com o conhecimento biológico e o conhecimento dos sistemas de valores humanos: a ética (Lolas, 2001).

Historicamente, a Bioética surge da ética médica e perpassa por quatro momentos significativos de mudança: a ética médica hipocrática; a moral médica de inspiração teológica; a contribuição da filosofia moderna e a reflexão sobre os direitos do homem na Europa (Sgreccia, 1996).

O contexto histórico sobre o comportamento dos médicos com os pacientes representa uma ética paternalista, porém, ao longo do tempo, estendeu-se o campo de estudo, de conceito e de ação da Bioética de acordo com diferentes perspectivas teóricas. Entre os autores que contribuíram para esta expansão destacam-se Reich, com a publicação da Encyclopedia of Bioethics em 1978; Hellegers com o conceito de ética aplicada; Jonas, que discute a ética Kantiana, a ética da responsabilidade por volta de 1992; Engelhardt com a publicação Fundamentos de Bioética em 1995 (Buey, 2000).

Considera-se atualmente que a Bioética é um movimento que tem como referência a ética aplicada à vida. Sarmento (2000, p.158) colaborou com este conceito afirmando que:

"A bioética busca maiores fundamentos para tomada de decisões e ações diante das contradições que se apresentam em nosso tempo, 
constituindo-se estas, a possibilidade de serem a expressão de novos direitos humanos e sociais que precisam consolidar-se como tais".

Para Sgreccia, (1996) a Bioética é uma metodologia interdisciplinar que se relaciona com a antropologia, teologia, deontologia médica, medicina legal e que deve assegurar sua referência na pessoa humana.

Há várias concepções de Bioética que trazem em seu bojo modelos teóricos-filósoficos diferenciados:

- Modelo sociobiológico, pautado na teoria da evolução natural onde a moral deve acompanhar tal evolução;

- Modelo liberal-radical ou subjetivista, onde a questão central é a liberdade e o princípio fundante é a autonomia; aliás, este é um modelo hegemônico pela Organização Mundial de Saúde- OMS;

- Modelo pragmático que tem como referencial a questão da sociedade, o bem comum e relaciona-se com o princípio da justiça;

- Modelo personalista que é fundamentado pelo reconhecimento da identidade e dignidade humana (Sgreccia, 1996).

Neste complexo universo da pluralidade Bioética está um de seus temas específicos, a Ética em pesquisa, que se caracteriza como tema central deste estudo.

Retomando a história é possível dizer que a preocupação com a ética nas pesquisas parte de um modelo de pesquisa biomédica, onde Pasteur é o precursor da denominada pesquisa experimental. Consolida-se uma ciência pragmática, a partir do século $\mathrm{XIX}$ até o século $\mathrm{XX}$, caracterizada pela ideologia do cientificismo, onde o pensamento era norteado sobre o pleno 
desenvolvimento da ciência em razão de solucionar os problemas da humanidade.

Contudo, na metade do século XX surgem grandes conflitos; a primeira e segunda guerra mundial traz para a ciência dilemas éticos que até então a cientificidade sozinha não responderia. A ciência que constrói uma medicina cada vez mais adequada æ̀s necessidades humanas é a mesma ciência que promove uma medicina capaz de matar pessoas em larga escala.

O término da segunda guerra mundial torna-se o marco de reflexão sobre a ética, pois trouxe à tona os crimes contra a humanidade como a utilização de prisioneiros em pesquisas letais.

Os grandes crimes nazistas ficaram mais evidentes devido sua derrota na guerra; e em conseqüência dessas barbáries cometidas contra seres humanos houve o Julgamento de Nuremberg, em 1945, que também marca um movimento mundial de organização de normas e regulamentos que orientam, a partir de então, as condutas éticas necessárias para as pesquisas com seres humanos, além do julgamento e condenação dos criminosos. Surgem daí os documentos que emanam da necessidade primordial de salvaguardar a vida humana, concretizando-se em princípios e regras éticas orientadoras para as pesquisas.

Os principais instrumentos normativos reconhecidos mundialmente são: o Código de Nuremberg em 1947; as Declarações de Helsinque em 1964, 1975, 1983, 1989, 1996 e 2000; o Relatório de Belmont em 1974/1978; as Diretrizes Éticas Internacionais para Pesquisas Biomédicas 
Envolvendo Seres Humanos do Conselho para Organizações Internacionais de Ciências Médicas (CIOMS) e Organização Mundial de Saúde (OMS) em 1982, 1996; e o Guia Internacional para Análise Ética de Estudos Epidemiológicos (CIOMS/OMS) em 1991 (Spinetti, 2001).

O Brasil acompanha essas regulamentações a partir de 1988, quando estabelece as Normas para a pesquisa em seres humanos, conhecidas como Resolução n. 01/88 do Conselho Nacional de Saúde - CNS subordinado ao Ministério da Saúde (MS). Durante 1995 e 1996 esta Resolução foi revisada por equipe multidisciplinar, resultando na aprovação da nova regulamentação de pesquisas envolvendo seres humanos no Brasil, a Resolução n. 196/96 do CNS/MS, denominada: DIRETRIZES E NORMAS Regulamentadoras de Pesquisa envolvendo Seres Humanos (Vieira \& Hossne, 1998).

A regulamentação brasileira apresenta em seu preâmbulo os princípios bioéticos que regem o documento como fundamento teórico; são eles: a autonomia, não-maleficência, beneficência e justiça. Portanto, de acordo com estes referenciais, a pesquisa com seres humanos no Brasil recebe uma identidade e orientação ética.

A partir da Resolução n¹96/96 são instaurados os Comitês de Ética em Pesquisa (CEPs) nas instituições de pesquisa do país. Deste momento em diante as pesquisas com seres humanos devem ser amplamente discutidas e refletidas no âmbito institucional. Segundo Hossne (2001b), já existiam cerca de 400 registrados no Conselho Nacional de Ética em Pesquisa (CONEP). 
Citando a Resolução n. 196/96, cap. II, inciso14 os CEPs são:

"Colegiados interdisciplinares e independentes, com 'munus público', de caráter consultivo, deliberativo e educativo, criados para defender os interesses dos sujeitos de pesquisa em sua integridade e dignidade e para contribuir no desenvolvimento da pesquisa dentro de padrões éticos."

Com esta responsabilidade os CEPs vêm desempenhado papéis significativos de análise crítica e ética de projetos de pesquisa em todo o país. O exercício ético faz-se cada vez mais rico em temas, conceitos, condutas, decisões no interior das discussões e críticas. As críticas direcionadas aos CEPs sugerem amplas reflexões e amadurecimentos no comportamento das pessoas que fazem parte deste contexto: os membros de CEPs, os pesquisadores, as instituições de pesquisa e os sujeitos das pesquisas.

A área da Saúde é um grande espaço produtor dessas reflexões, pois está diretamente relacionada com as limitações da natureza humana, a vida e a morte, por exemplo.

Pensando na relação pesquisador e CEP, surge o interesse em estudar as concepções dos pesquisadores a respeito de Ética em Pesquisa e, conseqüentemente, identificar os valores que são atribuídos aos sujeitos de pesquisa de acordo com a visão do pesquisador.

Este assunto tem sua origem com o processo de busca da pesquisadora quanto ao seu questionamento sobre os vários ramos e "problemas" que remetem à ética: o que seria salutar compreender? 
Partindo da experiência cotidiana como relatora de pareceres científicos, foi verificada a dificuldade de compreensão de alguns autores de projeto de pesquisa quanto aos roteiros de questionários e entrevistas referentes a alguns pontos que mereceriam atenção para um "pensar sobre o outro".

Foi o ponto de partida!

A indignação de pesquisadores quanto às avaliações das relatorias dos Comitês de Ética em Pesquisa sobre seu projeto é um fato. Verifica-se isto detalhadamente neste mesmo trabalho quando aborda-se os CEPs. Porém, essa indignação apresenta-se mais fortemente quando 0 pesquisador realiza pesquisas não clínicas (termo muito utilizado entre os cirurgiões-dentistas). O questionamento sobre o "por quê vão mexer na minha metodologia?", ou "por quê alterar aquilo que quero perguntar para o meu participante?" é muito habitual. Ou ainda "por quê demoram tanto em aprovar meu projeto quando ele não causará nenhum risco ao paciente?"... "só farei perguntas!"... "não farei intervenção invasiva !"

Esta poderia então ser a questão! O que significa riscos para o pesquisador da Odontologia?

É nesse universo que este trabalho pretende desenvolver-se, mais precisamente sobre a compreensão do pesquisador sobre Ética, Pesquisa (método qualitativo), Valores e Seres Humanos.

$\mathrm{Na}$ literatura há um elenco de trabalhos que colaboram e fundamentam a discussão sobre o tema. Apresenta-se, desta forma, diferentes paradigmas provenientes de visões teóricas e metodológicas da 
pluralidade do saber ético, além do discurso do pesquisador sobre essas questões.

"Se o futuro do homem está hoje condicionado pela bioética, esta tarefa Ihe é inalienável. Isto significa dizer que no presente, o homem como fim último é questão central, ou seja, a ética é, ainda, tema central de nossas vidas. É horizonte, é desafio, é construção do homem, humanizando a si mesmo" (Sarmento, 2000, p.169).

Este trabalho tem o desafio de ilustrar os dilemas éticos do pesquisador da Odontologia e refletir sobre os valores imbricados nas ações de pesquisa com os sujeitos envolvidos: a pessoa. Inicia-se uma procura por elementos que identifiquem ou singularizem o saber ético do pesquisador, e muito mais, insere-o numa relação solidária, compartilhando seus pensamentos, seus conceitos e preconceitos, seu conhecimento e suas emoções relacionados à Ética. 


\section{REVISÃO DA LITERATURA}

Ética em pesquisa é hoje um tema bastante discutido e abrangente nas diversas áreas do saber. A reflexão sobre este tema é também controversa e depende de qual paradigma do conhecimento se adota para compreendê-la, além do lugar de visão que a pessoa está localizada para a reflexão.

Para a compreensão de um determinado assunto, neste caso a ética, faz-se necessário buscar a ontologia da palavra em seu sentido histórico; assim, é possível iniciar a reflexão contextualizando sobre dois questionamentos:

1- Por que ética em pesquisa?

2- A preocupação com a ética é uma questão atual?

Durand (1995, p.5) apresenta essas questões como dilemas éticos relacionados ao comportamento humano, tais como:

"É preciso prolongar a vida de um canceroso em fase terminal?, reanimar um velho que não tem mais o gosto de viver?, tratar de um recém-nascido gravemente mal formado? Pode-se esterilizar os 'deficientes' mentais? É aceitável organizar-se um banco de esperma a partir de doadores que tenham recebido um prêmio Nobel? A 
sociedade deve admitir os bebês de proveta, os 'ventres de aluguel'? Pode-se fazer experiências com seres humanos? E que pensar das manipulações dos 'gens' para determinar a identidade dos indivíduos?" (grifo nosso)

Ao longo do tempo a sociedade tem conduzido à elaboração de respostas relativamente simples e, æ̀s vezes, unânimes. Porém, com a aceleração do progresso científico questões éticas têm levado todos a se colocarem frente a novas reflexões, æ̀ quais não são mais unânimes, mas amplamente discutidas, suscitando deliberações de conceitos e paradigmas relativamente diversificados e até angustiantes; no entanto, obrigam o indivíduo a se posicionar frente ao dilema ético e seus próprios códigos de valores.

Gelbier et al. (2001b) afirmaram que há uma urgente necessidade de revisão de atitudes, pois o conhecimento e as expectativas da sociedade em relação aos profissionais de modo geral são alterados de acordo com o tempo e contexto histórico.

Todo ser humano nasce no interior de um contexto sócio-históricocultural que o determinará como "Ser Social" a partir das opções que lhe são apresentadas e das escolhas que faz; e estas estão diretamente ligadas aos seus Valores, Moral e Ética em confronto aos encontrados na sociedade em que vive.

Tal discussão aponta a necessidade de distinguir os conceitos pontuados na literatura sobre Valor, Moral, Ética e Deontologia. 


\subsection{Valor}

A palavra valor significa "qualidade que faz estimável alguém ou algo; valia; importância de determinada coisa" (Ferreira, 1993, p.558).

Para Cohen \& Segre (1995) Valor é a subjetividade criada por uma cultura e sociedade. Entende-se que Valor é algo que preconiza o sujeito, no sentido de ser próprio do ser humano.

Quando se afirma que Valor é próprio "do sujeito" é possível compreender a extensão do significado da palavra. É admissível dizer que Valor "é aquilo que vale para mim". Assim o que realmente "vale para mim" faz parte de um processo de identificação pessoal. A busca do "EU", a interrelação com o homem.

"Quando um homem perde uma perna ou um olho, sabe que perdeu a perna ou o olho; mas se ele perdeu o eu - se perdeu a si mesmo - não é capaz de saber disso, pois já não está mais ali para sabê-lo" (Sacks citado por Alves, 2001; p.49).

Serrão $(2001)^{*}$ comentou que todo o conhecimento é arquivado na consciência em forma de Valores, ou seja, aquilo que se conhece está determinadamente envolvido com o Valor que lhe é atribuído por cada indivíduo; daí compreende-se as representações dos Valores, ou seja, aquilo que é bom, mau, belo, feio e outras extensões valorativas que o homem vai arquivando como idéia para si próprio.

\footnotetext{
* Daniel Serrão, palestra sobre Fundamentos da Bioética, Seminário de Ética em Pesquisa com Seres
} Humanos realizado na FOUSP nos dias 04 e 05 de dezembro de 2001. 
O processo de conhecimento não é imutável, as idéias se transformam no decorrer do desenvolvimento da personalidade do homem. Ao longo de sua própria história o homem vai adquirindo seus novos valores, seus novos conhecimentos, quase sempre partindo de um modelo préexistente.

O mesmo autor também afirma que a vida humana é anterior a todos os valores, por isso nada chega à inteligência se não for através dos sentidos. Estar vivo é condição ética. É esta condição que oferece margem à valoração das coisas e que dá sentido à vida. Assim, quando pessoas afirmam que o sentido da vida está nos valores ao qual cada um adquire, é salutar compreender que valores são esses que fazem parte da essência do ser humano.

Falar do ser humano é falar de relação. Todos os seres humanos são seres em relação, são responsáveis uns pelos outros e a responsabilidade da sociabilidade humana é respeitar o outro. Neste sentido, encontra-se um Valor. O valor do respeito ao ser humano. “(....) Somente através de um real envolvimento humano será possível repensar os próprios valores e descobrir outros" (Alves, 2001, p.128).

Para Silva (1998) o que distingue assim tão fortemente o universo humano do mundo natural é o Valor. O percurso da história do ser humano é um processo de construção dos valores.

Valor para Heller (1991, p. 8) significa “(...) aquilo que produz diretamente a explicitação da essência humana ou é condição de tal explicitação.” Enquanto para Weil (1993, p.47) Valor “(....) é uma variável da 
mente que faz com que o ser humano decida ou escolha se comportar numa determinada direção e dentro de determinada importância."

"O princípio da defesa da vida física sanciona o valor fundamental da vida e sua inviolabilidade, sendo a vida o direito primeiro e o valor primeiro da pessoa, sem a vida todos os outros valores não poderiam ser manifestados" (Alves \& Ramos, 2002, p.60).

\subsection{Moral}

O significado da palavra Moral quer dizer: "conjunto de regras de conduta ou hábitos julgados válidos, quer de modo absoluto, quer para grupo ou pessoa determinada" (Ferreira, 1993, p.371).

Muitos relacionam a palavra Moral como algo pré-determinado, que foi e é imposto por pessoas ou grupos da sociedade. O que é atribuído à Moral geralmente são, no senso comum, as normas e as regras de uma determinada cultura e sociedade e em determinado espaço de tempo.

A palavra Moral leva o indivíduo naturalmente a provocar juízo de valor ao que meramente lhe apresenta. Associa-se Moral a "moralidade" que é tão íntima nos longos discursos da esfera política. Pode-se também pensar sobre a forma de comportamento de um determinado grupo em sociedade. É geralmente lhe atribuído o "peso" da imposição antecessora das relações humanas. O que foi dito e não escrito em como o indivíduo deve se comportar. É esse o efeito da reflexão sem o acompanhamento racional de sua história. 
Mais uma vez, está explícito a necessidade de buscar a ontologia do que se quer entender. A Moral é aqui voltada ao seu sentido original. De quê realmente veio esta expressão senão de valor?

A priori, o indivíduo busca no seu arquivo valorativo o que se tem de conceito sobre a palavra Moral. O significado desse conceito se representa de forma diferenciada de acordo com os paradigmas nele concebidos.

Aquino citado por Lauand (1997) diz que Moral é o ser do homem. Quando ele fala em "ser" entende-se essência, assim, Moral vem originalmente do próprio homem no processo de sua formação e autorealização. Neste sentido, a Moral está associada à natureza humana. As regras ou normas morais são parte de uma totalidade que é o ser humano. O homem está constituído de uma unitotalidade que o identifica como ser e ser social.

Sobre a unitotalidade citada acima Heller (1991, p. 5) explicou que a Moral é uma relação entre as atividades humanas: “(....) a conexão da particularidade com a universalidade genericamente humana".

Esta universalidade (totalidade) é o real, o locus onde está o ser, a estrutura social ao qual pertence, a sociedade. Nesta estrutura, vinculada com a particularidade do ser, está contida a Moral. A Moral pertence ao homem como meio de expressão de sua particularidade.

Segundo Vieira \& Hossne (1998), a Moral vem dos costumes; os valores morais foram consagrados pela sociedade pelo uso e costume eleitos como valores que devem ser respeitados. A Moral então, vem ao encontro do Homem, ou seja, é um processo do externo para o interno. 
Segre (1995) afirmou que a Moral é o fruto da interação entre os juízos de valores individuais e aqueles impostos, sociais.

Já Passos (1994, p.107), desenvolveu o tema refletindo sobre a origem das normas morais. Esta autora enfatiza que desde quando os homens resolveram superar as relações instintivas (do processo natural de humanização) e passaram a conviver em sociedade é que surge a real necessidade de orientações de conduta humana, também reconhecidas como normas morais. Essas condutas foram criadas pelos próprios homens para garantir a convivência e a possibilidade de continuidade da vida humana. Assim, a Moral, nesta ótica é norteadora dos padrões de comportamento da sociedade em cada momento histórico.

"A moral não possui sua origem fora do homem e sim no homem. Não nesse homem meio e sim no homem fim. No homem que pensa, sente, transforma e constrói. No homem cujo a natureza é um 'complexo das relações sociais' (....)".

A mesma autora ainda reafirmou que a prática Moral é uma atividade essencialmente humana que articulada ao projeto global da sociedade, identifica-se à concepção de homem, da vida e da cultura, ou seja, esta atividade humana é vinculada com a sociedade e expressa-se de acordo com as concepções as quais ela está inserida em seu momento históricocultural.

Araújo (1999) considerou Moral como a ciência das leis ideais que dirige as ações humanas; ou seja, em sua concepção é também a 
necessidade de viver em sociedade que a Moral se estabelece na prática da vida.

É visível a presença dos diferentes conceitos do que é Moral nas diversas correntes de pensamento. O significado desta diversidade é o elemento plural do conhecimento científico que vislumbra possibilidade de encontros e desencontros teóricos filosóficos. O ponto de partida parece ser o homem, como essência de uma relação, a relação com o universo humano.

"A moral autoritária e ranzinza faliu. É hora de apostar na ética da responsabilidade e da discussão (....) sem excluir uma reflexão crítica e rigorosa" (Josaphat, 1997, capa).

\section{3 Ética}

A palavra Ética significa "estudo dos juízos de apreciação referente à conduta humana, do ponto de vista do bem e do mal" segundo Ferreira (1993, p. 235).

Gelbier et al. (2001a) apontaram que a palavra ÉTICA é derivada do Grego e a palavra MORAL do Latim, porém sinalizam que seus significados são semelhantes. Para os autores Ética é geralmente utilizada quando falam sobre o estudo ético referente aos padrões morais reconhecidos.

O percurso da compreensão deste tema inicia-se no momento em que identifica Ética como uma categoria filosófica. A origem da palavra respaldase sob a lógica da Moral e do Valor. Neste sentido, Ética vem a ser inteligível 
sob o seu princípio, sua relação com a Moral e consequentemente com os Valores.

Para Hossne citado por Alves (2001, p.30) "ética é o conjunto de valores do próprio indivíduo, que envolve patrimônio genético, processo educacional, valores morais, sentimentos, construção de personalidade e que vem de dentro para fora(....)".

Serrão (2001)* afirmou que a Ética faz parte do exercício intelectual, sendo qualidade particular do pensamento humano. Esta denominação suscita sua aproximação com a Moral, que é também preconizada pelo pensamento humano. Porém, dá-se a Ética uma extensão de ação que a particulariza de forma significativamente distinta no campo do comportamento humano. A Ética é a estrutura da personalidade humana.

Discursa-se sobre Ética nas diversas áreas das relações sociais. Nos dias de hoje é comum o termo ser associado a "chavões" públicos, no exercício profissional, nas relações interpessoais, nos inúmeros setores de intervenção humana. O que parece ser razoável é admitir que em sua essência todos os ramos em que a citam há uma verdade ética, a de posicionar-se sobre o mundo ou sobre as coisas. Posição interpretada como conduta; é a necessidade de um parâmetro verdadeiro de comportamento que o homem procura e se expressa diante do mundo. Mas que parâmetro pode ser este?

\footnotetext{
* Daniel Serrão, palestra sobre Fundamentos da Bioética, Seminário de Ética em Pesquisa com Seres Humanos realizado na FOUSP nos dias 04 e 05 de dezembro de 2001.
} 
A complexidade da razão humana é acima de tudo um conjunto de necessidades individuais e coletivas. O homem constrói sua história a partir do que ele é, como ser, e do que está chamado a ser, em sociedade.

Para Cohen \& Segre (1995, p.13 e 22) o sentido da Ética é reservado como fundamental o respeito ao ser humano. Assim também se configura numa categoria de Valor "A pessoa não nasce ética, sua estruturação ética vai ocorrendo juntamente com o seu desenvolvimento(....) A humanização traz a ética no seu bojo."

Os autores desenvolvem o tema partindo do pressuposto que é possível compreender o processo Ético a partir da observação da instituição família. O indivíduo não nasce com o conceito de família constituído, ele irá construir este conceito através das suas percepções e vivência do contexto sócio-familiar ao qual está inserido. E assim é o mesmo processo com os conceitos de Valor, Moral e Ética.

Ainda para estes autores a Ética se fundamenta em primeiro lugar, na percepção dos conflitos, ou seja, ter consciência deles; Segundo, na autonomia, a condição de posicionar-se entre a emoção e a razão; Em terceiro, a coerência.

Consciência, autonomia e coerência são para os autores, pressupostos básicos para realização de julgamentos éticos e afirmam que a diferença entre Moral e Ética é que, enquanto para que a primeira funcione ela é imposta e para a Ética, deve ser percebida.

"(....) ser ético é poder percorrer o caminho entre a emoção e a razão, posicionando-se, de modo autônomo, (....) na busca de uma posição 
integrada, compatível com a prática da vida" (Cohen \& Marcolino, 1995, p.51).

A autonomia é um princípio filosófico e da ação humana e sua discussão será apresentada no item referente a Bioética.

Hossne (2001)* apontou que o processo de análise Ética é do interno para o externo, ou seja, inverso no que diz respeito a Moral. A Ética se dá pela avaliação crítica dos valores que se quer adotar e ainda afirma que: "não existe Ética sem liberdade." Fazer opções de valor, por mais conflituosas que sejam, é primordial para o exercício ético.

Outra condição necessária para este exercício ético é o "não preconceito", "não aceitar nem praticar coerção", "ter humildade", "ter a grandeza de aceitar a verdade". Assim, sobre essas condições o mesmo autor conclui que a Ética é nosso insight do dia a dia. Exerce-se avaliação ética no cotidiano interno e externo das relações humanas.

Vieira \& Hossne (1998) relataram que, de maneira mais superficial, a Ética pode ser compreendida como julgamento, e esse julgamento pode ser questionado e justificado de acordo com os princípios aos quais são orientados.

Complementando este raciocínio, Silva (1998) dizia que a Ética é o domínio dos juízos de valor. Ferreira (1993, p.322) definiu juízo "o ato de julgar, adquirir opinião"; assim também é possível entender Ética como o domínio dos julgamentos individuais com base nos Valores aos quais cada 
um adquire e acredita. Silva (1998, p.87) acrescentou que esses juízos de valor também se remetem àgeneralidade, ou seja: "Devemos agir como se o critério de nossa ação devesse estender-se universalmente. Qualquer ato que não seja susceptível de universalização se autocontradiz em termos morais."

O autor continua a questão comentando que esse conceito tem influência teórica na filosofia de Kant onde "o critério universal é que deveria pautar o juízo moral". Verifica-se como a expressão confunde-se entre exercício ético e juízo moral.

Para Heller (1991, p.13) "Todo juízo funciona sempre, explícita ou implicitamente, como parte da totalidade de uma teoria, de uma concepção do mundo, de uma imagem do mundo".

Enquanto Passos (1994, p.106) desenvolveu a questão afirmando que:

"A verdadeira ética não dogmatiza o certo e o errado, o bom e o mau. Ao contrário, os entende como dinâmicos, pois representativos de avaliações historicamente circunstancializadas. Do mesmo modo, não impõe uma única possibilidade ética. Respeita a existência de diferentes ordens de valores, representativos de finalidades diversas, decorrentes da faculdade de escolha dos indivíduos".

Acompanhando esta afirmação, deve-se estar atento em não cair no relativismo, doutrina bastante defendida enquanto fundamento Ético. Este não parece ser a postura adota pela autora, em seu texto está claro sua predominância da vertente teórica-metodológica do Materialismo Dialético 
enfatizado em algumas de suas discussões: "(...) a nossa análise da realidade se dá através de uma relação dialética entre sujeito e objeto, de modo que ela representará as marcas do objeto, assim como as do sujeito" (Passos, 1994, p.110).

Ainda na tentativa de compreender o significado da Ética, apresentase a afirmação de Araújo (1999), que a enfatizou como uma relação entre o comportamento moral e as necessidades e interesses sociais. Mais uma vez encontra-se o ponto de inclusão ética: o comportamento, o uno (o "eu") e o múltiplo (o "todo", a sociedade). Estes fatores relacionados se transformam em exercício ético.

A autora define Ética como a busca, dentro de um contexto e processo, de definir um "critério de justa escolha". Afinal, o quê é "justa escolha"? Seria a melhor opção? O melhor caminho? Aquilo que é bom para um vale para o outro?

Ramos (1994) comentou que a Ética pode ser compreendida como o "bem comum". Quando parte para a fragmentação de interesses poderá também perder a consciência dos valores ontológicos de unidade.

Aquino citado por Lauand (1997, p.10) respondeu algumas destas questões quando afirma que existem leis (morais) que estão impressas no ser do homem, assim, o que é realmente bom para o homem, é para os homens enquanto essência. Na subjetividade do pensamento humano sabese e distingue-se sobre o que é bom e o que não é, pois a qualidade do ser é estar próximo as suas raízes humanas e de distinguir naturalmente a diferença entre o "bom" e o "mau", mesmo quando não há o exercício, é 
necessário o hábito. "As virtudes nos aperfeiçoam para que possamos seguir devidamente nossas inclinações naturais (....) A aquisição de virtudes é auto-educação para aquilo que objetivamente é bom."

Durand (1995) afirmou que a Ética provém da "mesma realidade que a palavra Moral". Esta realidade que o autor comenta é a natureza humana. O fato de identificar sua origem no mesmo ponto de partida não limita sua ação. Os percursos da Moral e da Ética têm significados similares e trajetórias historicamente distintas.

Para Fortes (1998) a atividade da Ética é a busca e o estabelecimento dos juízos que justificam o que "deve ser feito", e não o "que pode ser feito". A Ética pode assim ser concebida como um caminho de indagações do agir e do como fazer, caminho este não orientado por documentos normativos. Não é propriedade da Ética a normatização, é sim, inicialmente, um processo de reflexão.

Sawaia $(2001)^{*}$ indicou a Ética como uma questão de potência e não de poder. O fazer ético está associado ao "capaz de", ou seja, o indivíduo não detém o poder de avaliar eticamente, ele tem oportunidade de avaliar a partir de sua capacidade ética, do seu potencial de julgamento e de escolhas. É próprio do homem a capacidade de preservar sua própria existência; e é necessidade humana a condição de ser livre para expressarse eticamente.

Weil (1993) dividiu a Ética em duas correntes: a "Ética Moralista" e a "Ética Espontânea ou Essencial".

\footnotetext{
* Bader Sawaia, Palestra sobre Ética em Pesquisa Social, Seminário de Ética em Pesquisa da FSPUSP, 20/11/01.
} 
- ÉTICA MORALISTA é definida como uma ética forjada, artificialmente criada pela pressão social, contrariando os supostos instintos egoístas, e posteriormente racionalizando pela inteligência sob a forma de máximas moralizantes elaboradas por filósofos religiosos ou materialistas, mas todos racionalistas.

- ÉTICA ESPONTÂNEA concebe o homem como um organismo vivo, que contém os princípios do universo. Os valores da Ética devem ser despertados. A Ética e seus valores são endógenos, isto é, vêm de dentro: uma vez despertados a sabedoria e o verdadeiro amor altruísta no ser humano, as regras morais passam a ser dispensáveis.

Complementando a questão, Sarmento (2000) considerou Ética como "uma construção sócio-cultural e política" de um povo cujo seu desenvolvimento deve ser visto sob o olhar reflexivo da vida social dos indivíduos; vislumbrar o contexto em que situa o homem é vê-lo em sua totalidade de ser humano.

Sawaia (1999) quando falava sobre Ética acrescenta a "paixão" como essência da ação Ética, diz que o homem só se aproxima da Ética quando percebe sua real necessidade de estar com o "outro", assim há uma relação de afetividade.

"O homem da necessidade não é antagônico ao homem da ética, e não é preciso superar um patamar mais alto de conforto material para pensar e agir eticamente, como sugerem algumas teorias, como se fosse preciso ter bens para ser ético e ter sutilezas emocionais" (Sawaia, 1999, p.114). 
Na tentativa de explicar o sentido da Ética na prática da vida é predominante o fator de posicionamento teórico dos autores em suas definições. A visão de mundo, do que é o homem, a vida e a sociedade vai caracterizando a que postura tomar diante de um fato, diante de um conceito. As pontuações dos autores aqui mencionados sobre Ética elucidam não somente sobre o que se pede (Ética), mas muito mais que isso, representam as formas de pensar e agir sobre o mundo de acordo com os seus referenciais ontológicos.

É salutar então, compreender o contexto em que a Ética está sendo expressa e vislumbrar a que categoria do pensamento ela é refletida em busca da verdade. A verdade pode ser entendida como o espaço entre o homem e o universo; o caminho do encontro é uma atitude Ética possível na maioria das colocações aqui referidas.

\subsection{Deontologia}

Segundo Ferreira (1995, p.201) a palavra Deontologia significa "o estudo dos princípios, fundamentos e sistemas de moral; tratado dos deveres". O termo é habitualmente utilizado para expressar os códigos éticos profissionais, limita a significação da palavra àárea das profissões.

Para compreensão da base Ética faz-se necessário o conhecimento da gama de setores em que ela está inserida, sendo que um deles pode ser a Ética Profissional. Assim, considera-se favorável o esclarecimento racional do que é "Deontologia" no aparato das diversas áreas do saber. 
Deontos significa DEVER, enquanto Logus quer dizer ESTUDO, ou seja, a palavra "Deontologia" sugere o ESTUDO DOS DEVERES.

De acordo com Segre (1995, p.27) o exercício profissional "(...) será uma questão de 'dever ser,' e não de 'ser', de acordo com o que definimos, e defendemos, para a postura ética individual, internamente assumida e progressivamente amadurecida."

Quando se fala em "dever ser" entende-se que é a forma pela qual uma pessoa ou um grupo, no caso, profissionais, decidem genericamente sobre a melhor conduta ética que deve exercer enquanto profissional de determinada área. Esta conduta associada às regras e normas éticas de sua profissão é caminho que deve ser seguido e respeitado para que não ocorra uma infração ética.

A diferença entre o significado de "dever ser" e de "ser" é que, aquilo que é próprio do ser humano no sentido de sua origem, criação e self faz parte do "Ser". A posição ética de um determinado indivíduo está diretamente vinculada ao seu "ser"; porém, quando este mesmo indivíduo atua profissionalmente e de acordo com as orientações de seu código de ética profissional, ele está exercendo o "dever ser". Desta maneira é possível interpretar que as atitudes enquanto profissional diferem das atitudes enquanto homem, e isto não deveria ser verdade. A lógica das ações humanas está envolvida no complexo de relações e de valores, e estas ações são intrinsecamente ligadas ao que o homem "é" e está chamado "a ser". A dicotomia que pode existir entre o campo pessoal e profissional deriva-se das ordens dos valores; a elegibilidade do lugar de importância de 
determinada conduta depende do contexto e da razão entre o que diz respeito ao singular e ao plural (o coletivo).

Para Durand (1995, p.15) "(....) é a pesquisa das exigências éticas ligadas ao exercício de uma profissão (....) 'códigos de deontologia'."

Todas as profissões regulamentadas possuem seus próprios códigos de ética profissional onde estão contidas as condutas necessárias que o indivíduo deve tomar em seu exercício de trabalho. Essas condutas são regidas por elementos de orientação que norteiam o fazer do profissional e dizem respeito aos seus deveres e direitos.

Os códigos Deontológicos encontram sua fundamentação nos vários princípios morais existentes no seio da sociedade. Como exemplo, Ramos (1994) verificou no Código de Ética Odontológica uma preocupação com as discriminações, seja contra os profissionais ou com os pacientes e neste sentido esta preocupação configura-se como linha fundamental deste Código. Assim, pode-se também associar esta preocupação com o princípio do respeito ao ser humano.

Ramos (1994) também levantou uma questão que é bastante refletida nas bases de discussões profissionais: o problema do "corporativismo". A defesa do interesse de uma classe não deve se sobrepor ao interesse maior, que é o da dignidade humana. São princípios básicos do exercício ético.

Já para Gelbier et al. (2001a) tradicionalmente a ética médica e odontológica referem-se aos padrões de competência profissional e sobre as condutas que cada profissional espera de seus membros. 
As primeiras normas éticas direcionadas a grupos profissionais conforme Samico et al. (1994) são de longa data, iniciando-se talvez com o Código de Hammourabi na Babilônia e o conhecido Juramento de Hipocrates (séc. V a. C.) que tratavam genericamente da ética médica.

O código de Hammourabi proclamava:

"Eu, Hammourabi, o rei atencioso e respeitoso com os deuses, com o fim de fazer brilhar a justiça no mundo terrestre (habitado), visando destruir o maldoso e o criminoso, para impedir que o poderoso abuse do fraco, (....), é a mim que o deus Anou e Enlil nomearam como rei para a felicidade dos homens. (....) meus ombros benfeitores estenderam-se sobre as vilas; tomei e coloquei sob minha proteção os homens dos países da Suméria e de Accad; (....) para não autorizar que o poderoso oprima o fraco, para assegurar os direitos das viúvas e dos órfãos, na Babylonia sob o comando dos deuses Anou e Enlil (....), com o intuito de assegurar a boa justiça no país, para formular decisões legais no país, escrevi minhas preciosas palavras sobre minha estrela e diante de minha imagem de rei justiceiro as coloquei" (grifos nosso)(Sayegh citado por Caggiano, 2002, p.97).

Este código não se tratava de um exercício profissional diretamente, porém constituiu referência para elaboração de novos códigos direcionados a área médica, como por exemplo a Lei das Doze Tábuas que continha penas severas aos cirurgiões.

O Juramento Hipocrático caracteriza-se como documento que norteou por mais de 2.500 anos a prática médica, influenciando ações paternalistas 
que até hoje perpassam na relação médico-paciente. Os princípios da nãomaleficência, beneficência e confidencialidade são apresentados neste documento:

"Eu juro, por Apolo médico, (....) Aplicarei os regimes para o bem do doente segundo meu poder e entendimento, nunca para causar dano ou mal a alguém. (....) Em toda casa, aí entrarei para o bem dos doentes, mantendo-me longe de todo o dano voluntário (....) Aquilo que no exercício ou fora do exercício da profissão e no convívio da sociedade, eu tiver visto ou ouvido, que não seja preciso divulgar, eu conservarei inteiramente secreto. (....)" (Vieira \& Hossne, 1998, p.111).

O Juramento de Hipócrates apresenta uma série de pensamentos e modelos que associam-se com a história da medicina. Os médicos eram considerados como deuses que tinham o poder e decisão frente aos outros seres humanos. Na menção sobre fazer o "bem" encontra-se o princípio da beneficência, porém neste modelo configura-se uma relação de dominação, pois o exercício do bem era praticado pelo médico que possuía o poder para fazê-lo e por que também era "bom", ou seja, o fundamento pautava-se na autoridade, o benefício era realizado pela "bondade" do profissional e não por que o paciente possuía o direito.

Assim como o princípio do benefício é também encontrado neste Juramento o entendimento sobre segredo profissional que dimensionará um padrão de ética profissional por longos anos e em diversos campos profissionais, influenciando a formação dos códigos deontológicos. 


\subsection{Experimentação em seres humanos}

Seres humanos são objetos de pesquisa biomédica desde o início da história da humanidade, a experimentação em seres humanos é mais vislumbrada a partir do final do século XIX (Winspear, 1981). Como já citado na introdução deste trabalho, a pesquisa experimental se consolidou como intervenção necessária e possível com Louis Pauster em razão de sua descoberta da vacina contra raiva. Muito antes já haviam experiências na medicina que trouxeram contribuições singulares para o conhecimento das doenças, suas causas e efeitos; cita-se por exemplo, Lancaster com o estudo sobre a prevenção do escorbuto, Jenner com a vacina contra varíola, dentre outros (Vieira \& Hossne, 1998).

Muitos foram os avanços da medicina na área dos experimentos com seres humanos, durante os últimos três séculos vêm-se testando vacinas, novos fármacos, testes diagnósticos, reprodução humana, genética etc. Não se poderia negar também que os "sucessos" algumas vezes decorreram de grandes tragédias, "insucessos" nos estudos com as pessoas.

Há um elenco de casos conhecidos na literatura que dizem respeito aos grandes abusos com seres humanos, desde práticas de violência orgânica/física æ̀̀ emocionais, que causaram transtornos psíquicos e até a morte.

Os relatos de abusos podem iniciar com os experimentos nazistas que são notadamente conhecidos pela barbárie provocada com os prisioneiros de guerra; as experiências pautaram desde testes de 
congelamento até experimentos com venenos seguidos de torturas, assassinatos e outros atos de brutalidade.

Um outro estudo, desvinculando-se do contexto de guerra, tratou de estudar a história natural da sífilis; é o caso de Tuskegee. Para levantar dados sobre a sífilis 408 pacientes (negros e pobres) foram mantidos sem tratamento, ou seja, os indivíduos participantes não foram informados que estavam participando de uma experiência; ao contrário, eram informados que estavam recebendo um "tratamento especial e gratuito". Este estudo começou em 1932 e só foi suspenso em 1972, 40 anos após o seu início. Durante todo esse tempo os indivíduos ficaram sem o tratamento, causando a morte para grande maioria. Na década de 1970 a experiência foi apresentada no Congresso Internacional sobre sífilis e suscitou em grandes elogios pois tratava-se de um estudo longitudinal que atingiu até outra geração, já havia filho de portador de sífilis sendo acompanhado, apresentando assim, o processo evolutivo da doença. O final desta história resultou em pedidos de desculpas públicas do então presidente dos Estados Unidos em 1997, além de indenizações às famílias das vítimas (Vieira \& Hossne, 1998).

A ciência que evoluiu trouxe também graves problemas para a humanidade, assim, pensar sobre o que poderia mediar esta relação, a ciência versus ser humano, foi e ainda é, missão da sociedade como um todo; tanto a acadêmico/científica quanto a comunidade em geral. 
"Vagarosamente, os pesquisadores começaram a perceber - e o público começou a exigir - que os estudos deveriam ser conduzidos de tal forma que não levassem em conta somente o avanço científico, mas também protegessem os direitos e o bem-estar das pessoas" (Pessini \& Barchifontaine, 1996, p.19).

\section{6 Ética em pesquisa}

Como já foi visto, desde Hipocrates (séc. V a.C.) existem normas e reflexões sobre Ética Profissional, porém a Ética em Pesquisa somente vem surgir sob o âmbito normativo há 50 anos; a utilização de Seres Humanos em experimentos é anterior a essas normativas.

Em 1947, foi criado o CóDIGo DE NUREMBERG, em razão do julgamento dos médicos nazistas durante a segunda guerra mundial. $\mathrm{O}$ foco deste código para orientação ética é o consentimento voluntário; neste momento vislumbra-se a necessidade de participantes de pesquisa consentirem voluntariamente sua participação; as pesquisas devem ter relevância social e também torna-se prioritário a autonomia do indivíduo frente ao processo de decisão em dar seu consentimento.

Já em 1964, foi elaborada a DECLARAÇÃo DE HELSINK, pela Associação Médica Mundial reunida na 18a Assembléia em Helsinque na Finlândia; esta Declaração complementa o Código de Nuremberg a partir de uma revisão de suas recomendações e são voltadas àpesquisas biomédicas. O documento trouxe contribuição principalmente no que se refere ao consentimento pós 
informado, pois apresenta a aplicabilidade das recomendações de acordo com várias situações; como por exemplo pesquisas que envolvam crianças, mulheres grávidas, pessoas com distúrbios mentais ou de comportamento. As pessoas só deveriam ser selecionadas para o estudo caso sua problemática esteja diretamente relacionada com a proposta da pesquisa, ou seja, que venha a lhe trazer algum benefício direto. As pesquisas devem proporcionar melhorias de diagnóstico e profilático e os interesses referentes aos seres humanos prevaleçam sempre sob os interesses da ciência e da sociedade (Spinetti, 2001).

A Declaração de Helsinque foi revisada e ampliada em 1975, 1983, 1989 e também em 1996, na África do Sul. Em 2000 na 52 ${ }^{\text {a }}$ Assembléia, essa Declaração foi rediscutida para a implementação de algumas mudanças; essa discussão foi objeto de muitos debates e controvérsias em todo o mundo, pois nesta Assembléia alteraram os textos da Declaração concernente ao tema sobre pesquisa clínica e o uso de placebo; alterações estas muito questionadas na comunidade médica mundial, inclusive no Brasil onde houve vários manifestos contrários às modificações.

"A conseqüência mais nefasta seria uma importante mudança nos padrões éticos mínimos que hoje são internacionalmente aceitos na condução de pesquisas que envolvem seres humanos" (Oselka, 2000, p.21).

A Declaração de Helsinque é referência em todo o mundo quanto as orientações éticas em pesquisas biomédicas, mesmo nos países em que já possuam seus documentos, o texto da Declaração se configura fundamento 
de construção de outras normativas sobre pesquisas envolvendo seres humanos.

A trajetória histórica internacional sobre as normatizações que incidem sobre pesquisas realizadas em seres humanos não param por aí: em 1982 também foram produzidas as "Diretrizes Internacionais para Pesquisas Biomédicas envolvendo Seres Humanos", pelo Conselho para Organizações Internacionais de Ciências Médicas (CIOMS), em colaboração com a Organização Mundial de Saúde (OMS); sendo em 1992 revisada e reeditada em 1996 com o título de DIRETRIZES ÉTICAS INTERNACIONAIS PARA Pesquisas Biomédicas envolvendo Seres humanos. Estas Diretrizes apresentam os princípios da autonomia, beneficência e justiça, que foram propostos inicialmente no RELATÓRIO BELMONT desenvolvido entre 1974 a 1978, enquanto fundamento necessário para avaliação ética das propostas de pesquisas. Além disso, segundo Fortes (1998, p.107):

"O texto conta com quinze diretrizes e atenta para as peculiaridades das diferentes realidades existentes nos países em desenvolvimento. Ressalta a proteção de grupos humanos vulneráveis - pessoas com transtornos mentais, crianças, prisioneiros, comunidades subdesenvolvidas, gestantes e nutrizes -, o consentimento em estudos epidemiológicos e multicêntricos e as pesquisas financiadas de fontes externas ao país onde é realizada. Vem reforçar o princípio da participação autônoma, da privacidade, da confidencialidade e sigilo dos dados e a necessidade dos comitês de ética em pesquisa." 
O CIOMS junto a OMS ainda produzem o GUIA INTERNACIONAL PARA ANÁLISE ÉtICA DE Estudos EPIDEMIOLÓGICOS em 1991 com o objetivo de apresentar normativa que assegure o respeito ao sujeito de pesquisa e que seja propiciado resultado às comunidades e indivíduos estudados; esta preocupação surge em decorrência dos estudos epidemiológicos sobre Síndrome da Imuno-Deficiência Adquirida (AIDS), desenvolvidos em todo o mundo (Spinetti, 2001).

Vários países adotaram as recomendações dos documentos ora apresentados; o desenvolvimento de normas que regulassem os procedimentos éticos de pesquisas que envolvem o ser humano transformou-se em necessidade fundamental para ciência e sociedade. Ainda com a existência de regulações internacionais, durante este percurso, foram presenciados abusos em experimentos com indivíduos, sendo muitas vezes necessário a elaboração de normas peculiares à problemática de cada país.

No Brasil, as primeiras normas nacionais sobre ética em pesquisa com seres humanos datam de 1988, com a RESOLUÇÃO № 01/88 do Conselho Nacional de Saúde (CNS), normatização esta que foi aplicada pela Comissão Intersetorial de Ciência e Tecnologia (CICT), do citado Conselho.

A Resolução nº 01/88 não trouxe grandes repercussões para o campo dos pesquisadores no Brasil, muitos alegam este fato devido sua deficiente divulgação, porém foi um marco divisor para o início da construção da reflexão ética no país em relação a pesquisas com seres humanos e 
suscitou organizações de estudo e de revisão do seu próprio texto, surgindo assim, a RESOLUÇÃO № 196/96.

A realização de pesquisas que envolvem seres humanos é rotina e realidade na história da produção de conhecimento em todo o mundo; suas repercussões transformaram a ciência e alteraram dogmas e paradigmas fortemente inquestionáveis; avançaram e ampliaram o mundo do saber; contribuíram com a tecnologia do mundo moderno e com todos os avanços nas áreas da saúde e sociedade, além de tantas outras contribuições na área do conhecimento. Muitos são os resultados, em razão deles também muitos fatos conhecidos e desconhecidos de "utilização" indevida de seres humanos foram feitas. Hoje, respeitar a integridade do ser humano sob seu aspecto físico, social, emocional e espiritual é uma exigência ética corrente e primordial na sociedade, inclusive quando da inserção do indivíduo como sujeito produtor do conhecimento. Para o pesquisador da área da Ciência da Saúde esse entendimento também é crucial para o desenvolvimento de seu estudo; o que parece ser razoável não é o fundamental. O reconhecimento desses fatores não o fazem seres "éticamente corretos" e nem é essa a pauta da discussão. A rotina das pesquisas biomédicas naturalmente sugere enfoque na preocupação da integridade física do participante da pesquisa.

\subsubsection{Resolução nำ 196/96}

Em 1996, foi elaborada e aprovada uma nova normatização sobre ética em pesquisa, com o objetivo de atualizar a Resolução anterior àluz do desenvolvimento científico e das reflexões éticas atuais. Deve-se a esta 
revisão o empenho do grupo de trabalho do CNS que caracterizou-se em trabalho multidisciplinar com a colaboração de vários setores da sociedade brasileira que representavam usuários, pesquisadores, instituições de pesquisa, dentre outros. As DiRetrizes e Normas Regulamentadoras de Pesquisas em SeRes Humanos são mais comumente conhecidas como Resolução nº 196/96, de 10 de outubro de 1996, do CNS, e seu preâmbulo afirma:

"Esta Resolução incorpora, sob a ótica do indivíduo e das coletividades, os quatro referenciais básicos da Bioética: autonomia, não maleficência, beneficência e justiça, entre outros, e visa assegurar os direitos e deveres que dizem respeito à comunidade científica, aos sujeitos da pesquisa e ao Estado."

O campo de aplicação desta Resolução é ampliado; não somente dirigido as pesquisas biomédicas mas precisamente também direcionada para orientações de pesquisas em áreas da educação, sociologia, ambiente, nutrição, psicologia, economia, física, ou seja, em todos os campos que realizem pesquisas que envolvam seres humanos direta ou indiretamente.

A Resolução nำ196/96 está fundamentada ética e juridicamente de acordo com documentos nacionais e internacionais que certamente dão ao documento consistência legal e de conduta moral que norteia hoje em dia as revisões éticas dos protocolos de pesquisa no Brasil.

"Certamente, não é somente porque existe uma norma legal ou deontológica que as pesquisas vão se adaptar inteiramente aos princípios éticos, pois, para que haja eficácia do conteúdo da 
Resolução, é preciso que se amplie a consciência dos pesquisadores e da sociedade como todo sobre o respeito à dignidade da pessoa humana, e para isso as normas expressas devem ser observadas enquanto importante instrumento pedagógico e não como mecanismo coercitivo para os pesquisadores" (Fortes, 1998, p. 108).

A Resolução nº 196/96 configura-se numa peça de natureza Bioética. Ela não é auto aplicável, não é uma lei nem estatuto; ela exige um exercício ético do seu usuário.

\subsubsection{Comitê de Ética em Pesquisa}

Nesse espaço, os COMITÊS DE ÉTICA EM PESQUISA (CEPS) foram criados por determinação da Resolução nº196/96, identificados como colegiados interdisciplinares que assumem a função de consultores e educadores no âmbito institucional; suas ações e atividades são direcionadas à defesa dos sujeitos de pesquisa quanto à integridade e dignidade e, no acompanhamento e desenvolvimento ético das pesquisas (MS, Resolução n 196, 1996)

Os CEPs têm, hoje, aproximadamente seis anos de institucionalização nas diversas Instituições de Ensino e Pesquisa do país. É notável o seu papel predominante no processo de qualificação ética dos projetos de pesquisa. Vale dizer que sua notoriedade e respeito são resultados inicialmente, da "obrigatoriedade", por parte de todos os órgãos de fomento à pesquisa, e das Instituições de Ensino e Pesquisa, de 
submissão das propostas de projetos de pesquisa aos Comitês, quer para a concessão de suporte financeiro e/ou bolsa(s), quer para a defesa do trabalho. Porém, sua repercussão não se limita a essas instâncias.

Assim, em relação aos CEPs, as possíveis contribuições éticas para os projetos de pesquisa são presumíveis, visto que é na fase inicial do projeto que o pesquisador submete-o à apreciação. Deste modo, é possível realizar mudanças e alterações que adeqüem o projeto aos fundamentos éticos. Nesse âmbito, também surgem amplas discussões e reflexões éticas, tanto por parte do relator membro do CEP quanto por parte do pesquisador, o que pode resultar em posições e no amadurecimento de posturas, contribuindo para o debate ético no interior das instituições.

Os CEPs são colegiados praticamente recém-criados nas Instituições de Ensino e de Pesquisa a bioética deveria ser disciplina ética básica nas discussões científicas e no desenvolvimento do ensino e da pesquisa no país.

\subsection{A bioética: princípios e fundamentos}

A Bioética surge por volta de 30 anos atrás, para compreender e refletir sobre a ética das ciências da vida, da saúde e do meio ambiente. É matéria que preocupa-se com todas as áreas do conhecimento e que pressupõe trabalho interdisciplinar. O olhar nas questões da área da saúde deve ser visto na interface das outras áreas, das outras ciências.

Muitos autores tentam definir os limites da Bioética, ressaltando seus objetivos e finalidades; A imensa gama de conceitos nascidos entre as 
décadas de 70 a 90 trazem a tona uma pluralidade de razões Bioéticas para o debate ético no mundo da saúde e da coletividade.

O grande precursor que define Bioética para além dos limites institucionais foi Van Ressenlaer Potter, em 1971; sua definição apontava para necessidade de uma "Bioética Global", que constituísse como uma ponte entre o conhecimento científico e a vida humana (Garrafa \& Costa, 2000).

$\mathrm{Na}$ busca de conhecer que áreas temáticas dizem respeito a Bioética Campbell (2000) indicou a definição da International Association of Bioethics (IAB), que entende o termo como o "Estudo dos aspectos éticos, sociais, legais, filosóficos e outros aspectos afins inerentes àassistência médica e æ̀s ciências biológicas."

Araújo (1999, p.43) colaborou com a definição de Bioética afirmando que:

"A concretização da ação recíproca da filosofia com o novo saber biológico, pode ser a Bioética.(....) é a parte da ética, ramo da filosofia, que trata de temas referentes à vida, à saúde e à morte. Engloba a ética médica, mas não se limita a ela. Seu universo é muito mais amplo e está relacionado com assuntos das ciências da saúde, que interessam a todos os profissionais da saúde e ao público e devem ser abordados dentro da própria sociedade."

Para Clotet (2000, p.111) a Bioética nasceu e se desenvolveu a partir:

" - dos grandes avanços da biologia molecular e da biotecnologia aplicada àmedicina realizados nos últimos anos; 
- da denúncia dos abusos realizados pela experimentação biomédica em seres humanos;

- do pluralismo moral reinante nos países de cultura ocidental;

- da maior aproximação dos filósofos da moral aos problemas relacionados com a vida humana, a sua qualidade, o seu início e o seu final;

- das declarações das instituições religiosas sobre os mesmos temas;

- das intervenções dos poderes legislativos como também dos poderes executivos em questões que envolvem a proteção àvida ou os direitos dos cidadãos sobre sua saúde, reprodução e morte;

- do posicionamento de organismos e entidades internacionais."

As diversas causas que motivaram o nascimento da Bioética são essencialmente ligadas à necessidade de revisão de condutas éticas e morais a respeito da vida, da saúde, do homem. Esta necessidade é logicamente mais evidente no âmbito da saúde e da medicina onde nasce uma política de reflexão e questionamento sobre as ações de intervenção da biomedicina no ser humano sob sua dignidade e identidade.

Segundo Pessini \& Barchifontaine (1998) o PRINCIPIALISMO é um dos paradigmas mais recorrentes na Bioética que originou os conhecidos princípios éticos básicos: a autonomia, não-maleficência, beneficência e a ¿ustiça. Esses princípios também orientam a normativa brasileira, a Resolução no 196/96 (grifo nosso).

Estes princípios surgiram da Comissão Nacional para Proteção dos Seres Humanos da Pesquisa Biomédica e Comportamental do Congresso 
dos Estados Unidos que tinha o objetivo de identificar princípios éticos norteares sobre investigação em seres humanos; em 1978 esta comissão publicou o conhecido Relatório Belmont que apresentava os três princípios: autonomia, beneficência e justiça. Já em 1979, Beauchamp e Childress acrescentam em publicação denominada Principles of biomedical ethics o princípio da não-maleficência (Barboza, 2000, p. 211).

Estes princípios servem como guia orientadores de reflexão ética nas ações voltadas aos experimentos e intervenções sob os seres humanos.

Salomão \& Silva (2002, p.88-89) compreendem estes princípios como:

- Autonomia: significa o respeito à pessoa; considera que o indivíduo deve ser autônomo para decidir suas ações, seus caminhos. É também identificado a preocupação com as pessoas que possuem autonomia "diminuída", a chamada autonomia restrita. "A autonomia é entendida como a capacidade de atuar com conhecimento de causa e sem coação externa."

- Beneficência: significa fazer o bem; é um princípio recorrente do Juramento hipocrático que o Relatório Belmont considera como obrigação. Ao longo do tempo a beneficência encontra referências éticas da tradição cristã àmarxista que evidenciam a necessidade de promover o bem.

- Justiça: "(...) é o que nos obriga a garantir a distribuição justa, eqüitativa e universal dos benefícios dos serviços de saúde." Cada um deve receber aquilo que lhe é de direito. 
Quanto ao princípio da não-maleficência Barboza (2000, p.211) o identifica como não causar mal a outro, ou seja, não prejudicar a pessoa sob qualquer aspecto. Este princípio não se dissocia do princípio da beneficência e muitas vezes está apresentado conjuntamente.

Os princípios acima aludidos são de origem americana que enquanto fonte Bioética podem ser compreendidos como procedimentos; a necessidade de estabelecer estratégias no campo da saúde trouxe à reflexão moral alguns "padrões" de diálogo; manter um caminho possível, visível e de fato. É a prática do consenso (Lolas, 2001).

O predomínio do principialismo nas correntes Bioéticas é um fato, há porém em destaque os inúmeros avanços nos debates com a pluralidade de paradigmas em todo o mundo. A sociedade européia demonstra mais claramente sua postura controversa quanto aos quatro princípios ora comentado.

Salomão \& Silva (2002) afirmam que prevalece na Bioética européia a dimensão social do ser humano onde é necessário conhecer o homem na sua totalidade, perfazendo uma perspectiva de personalização humana. Para Schramm (1997) o modelo europeu é inspirado no PERSONALISMO ou ANTROPOLÓGICO influenciado pelo movimento dos direitos humanos na França e pelo pensamento católico progressista.

A Bioética na América Latina desenvolve-se enquanto movimento preciso e necessário mais fortemente por volta dos anos 80; a crítica ao principialismo é associada ao privilégio de um dos princípios sob os outros; a autonomia é no contexto norte-americano mais prevalente que por exemplo 
a beneficência ou a justiça, ressaltando um individualismo que muitas vezes não se faz capaz de responder questões mais amplas nos dilemas éticos.

Anjos (2000) relatou que o grande problema da Bioética na América Latina é o enfrentamento das desigualdades sociais, o Brasil é por exemplo, país em relevo nesta preocupação. As contradições sociais estão a tona e perpassam todo o campo da vida, assim, reproduz-se em desigualdades na educação, no trabalho, na moradia, alimentação, ou seja, em todas as chamadas necessidades básicas do ser humano. Como fazer Bioética neste contexto? É preciso "encarar" a questão.

"A Bioética recupera sua capacidade de indignação diante dos contrastes que estamos habituados a ver sem solução. O amor, que a impulsiona, busca eficácia de transformação social. E a Bioética se faz com razão e coração" (Anjos, 2000, p.62-63).

Alguns outros princípios são mencionados por diversos autores; destaca-se o princípio da ALTERIDADE pela efetiva menção no discurso bioético. A alteridade enfoca a pessoa enquanto "fundamento de toda a reflexão e de toda a Bioética". O ser humano deve ser essencialmente considerado enquanto núcleo da relação ciência e sociedade. O "outro" é o ponto de partida e o elo de ligação para discernir entre opções valorativas, como o bem e o mal (Pessini \& Barchifontaine, 1996, p.46).

Há também o princípio da SACRALIDADE DA VIDA HUMANA que emana da necessidade do respeito à vida pois ela é o fundamento de tudo, da existência humana. Na visão teológica, a vida é um dom sagrado, o homem foi criado à imagem e semelhança de Deus. Assim é considerada a 
dignidade da pessoa humana enquanto fonte inexorável de valor. O respeito àdignidade da pessoa é também fundamento de princípios éticos (Salomão \& Silva, 2002).

"A formulação de tais princípios se dá de modo amplo, para que possam reger desde a experimentação com seres humanos até a prática clínica e assistencial. Sua observância deve ser obrigatória, sempre e quando não entrem em conflito entre si, caso em que se hierarquizam conforme a situação concreta, o que significa dizer que não há regras prévias que dêem prioridade a um princípio sobre outro, havendo a necessidade de se chegar a um consenso entre todos os envolvidos, (....)" (Barboza, 2000, p. 211-212)

Para finalizar a discussão é salutar destacar o fundamento da Bioética, pois compreende-se que fundamento precede ao princípio. Ressalta-se aqui que o reconhecimento da dignidade e identidade da pessoa humana é fator básico para construção de princípios. Segundo Sgreccia (1996), a tradição personalista é caminho indispensável para compreensão da dignidade humana, pois estuda a razão do homem enquanto ser essencial, transcendente e digno.

O autor ainda acrescenta quatro princípios fundamentais, movidos pela concepção personalista:

- Princípio de defesa da vida física: ressalta-se que o direito à vida precede o direito à saúde, sendo a saúde uma qualidade da pessoa que vive; 
- Princípio da liberdade e responsabilidade: sanciona a obrigação moral do indivíduo com a vida; a liberdade é limitada pela responsabilidade;

- Princípio da totalidade e terapêutico: a corporeidade humana é todo unitário, resultante de partes distintas e unificadas orgânica e hierarquicamente entre si pela existência única e pessoal; ao terapêutico é atribuído a noção de proporcionalidade, considerar os riscos, danos e os benefícios que podem trazer à pessoa;

- Princípio da sociabilidade e subsidiaridade: é a realização do bem para os outros; a eqüidade é palavra constante neste princípio e deve ser compreendida pela necessidade de existir uma comunidade organizada que garanta o acesso a saúde em sua totalidade.

Assim, a Bioética personalista não invalida os quatro referenciais do principialismo, mas chama atenção para a necessidade de fundamentá-los adequadamente, sugerindo a hierarquização dos mesmos como determinantes para apreensão da realidade e do respeito ao ser humano. Desta maneira, sugerem que o benefício anteceda a autonomia e em seguida, o da justiça (Sgreccia, 1996). 


\section{PROPOSIÇÃO}

O presente trabalho propõe identificar e analisar, àluz das reflexões bioéticas, o discurso do pesquisador da Odontologia sobre:

- a visão de ética em pesquisa com seres humanos;

- a concepção de sujeito de pesquisa;

- a utilização das técnicas, questionários e/ou entrevistas. 


\section{MATERIAL E MÉTODO}

\subsection{Material}

Para a realização das entrevistas, utilizou-se um roteiro de questões (Anexo 1) que interessam e direcionam ao objeto da pesquisa, concebendoo como auxiliar no processo de diálogo. A entrevista semi-estruturada é o ponto de partida do investigador para o desenvolvimento do diálogo entre investigador-participante; trabalhar com a espontaneidade do participante propicia uma linha de pensamento, um contexto e um estímulo para chegar ao objeto-conteúdo do estudo de forma satisfatória.

A pesquisa de campo foi realizada no período de julho a setembro de 2002, com 28 voluntários de ambos os sexos, pesquisadores da área da saúde, especificamente da Odontologia, alunos de pós-graduação de mestrado, doutorado e professores da Faculdade de Odontologia da Universidade de São Paulo (FOUSP), que foram abordados em seus locais de trabalho. 


\subsection{Método}

O estudo baseia-se em três momentos: no primeiro momento apresenta-se as categorias de análise que a literatura oferece a respeito de Ética e Ética em pesquisa. O segundo revela o discurso do sujeito da pesquisa (pesquisador) sobre o tema; a interpretação do discurso sob esses paradigmas é o terceiro momento que está associado aos resultados e discussão do trabalho.

Adere-se ao método qualitativo de pesquisa que tem como característica primordial a compreensão da relação sujeito-objeto como dinâmicas. Segundo Nogueira-Martins (2001), no método qualitativo aplicado à pesquisa envolvendo seres humanos, a relação de conhecimentos dá-se igualitariamente, ou seja, a pesquisa é feita numa relação de troca, onde o "critério de cientificidade passa a ser a intersubjetividade". O pesquisador que realiza uma pesquisa qualitativa geralmente busca o entendimento da subjetividade humana. E é a esse respeito que trata o trabalho.

Identificar os "meandros" dos discursos, das falas do "outro" não é tarefa fácil; o que parece também não ser fácil é vislumbrar a subjetividade humana que está presente no interior desses discursos. Mas, então, por que fazê-lo?

É essa a possível inestimável contribuição de uma avaliação qualitativa. Apresentar o que não se dá imediatamente, o que não está escrito, mas reconhecer o valor intrínseco do conteúdo com a razão e com a emoção. É uma relação. É uma relação qualitativa de aprendizagem do 
conhecimento. É tanto possível quanto necessária para a percepção, no mínimo, crítica do real.

Nesta pesquisa utiliza-se da técnica de ANÁLISE DE CONTEÚDO como instrumento mediador de interpretação do real ora proposto.

"A análise de conteúdo não fica apenas nas fichas, nos relatórios, nas gravações, porque sabe que isto é instrumento, vestimenta, aparência. É preciso ir além disso (....) Saborear as entrelinhas, porque muitas vezes o que está nas linhas é precisamente o que não se queria dizer. Surpreender as insinuações (...) Escavar os compromissos (....) Explorar vivências (....) Compor a intimidade da vida cotidiana (....) Levar ao depoimento tão espontâneo que a diferença entre teoria e prática se reduza ao mínimo possível, de tal sorte que aquilo que se diz é aquilo que se faz" (Demo, 1995, p.43).

A técnica citada, Análise de Conteúdo, foi elaborada e desenvolvida para inicialmente quantificar dados discursivos que se apresentavam com freqüência nos conteúdos do diálogo. Bardin (1979) é referencial como autor que descreveu teórica e metodologicamente a trajetória deste instrumental de análise. Porém, segundo Gomes (1994), atualmente a técnica é compreendida muito mais como um "conjunto de técnicas", que podem contribuir satisfatoriamente com a "verificação de hipótese e/ou questões" e na função da "descoberta do que está por trás dos conteúdos manifestos". Além disso, o mesmo autor também apresenta o emprego da técnica por alguns caminhos. 
No entanto, Amaral (1987) afirmou que a necessidade primordial na análise de conteúdo é resgatar a narrativa, que não é nada mais do que o resgate do próprio sujeito, permitindo uma consciência do pesquisador, do que se está fazendo e do objetivo que se está perseguindo.

Gomes (1994) considerou "unidades de registro" a forma possível para verificação do conteúdo dos discursos. As "unidades" poderão ser palavra, frase, tema, personagem, dentre outras, inseridas no contexto das mensagens. A "unidades de contexto" é também fase importante para o desenvolvimento do trabalho no sentido de inseri-las no seu lugar. E, por fim, estabelece-se categorias com a finalidade de elucidação do trabalho.

Neste trabalho, opta-se pelo caminho acima descrito para a verificação do conteúdo dos discursos dos participantes.

Na busca pela melhor compreensão desta técnica e na preocupação de não representar mera citação de referencial metodológico, buscou-se entre pesquisadores orientações, através de suas experiências, sobre o "como fazer?", "como iniciar?". O que foi saldado é de grande contribuição para o amadurecimento do pesquisador como responsável analítico do produto "bruto" de seu trabalho.

"Na investigação social, a relação entre o pesquisador e seu campo de estudo se estabelecem definitivamente. A visão de mundo de ambos está implicada em todo o processo de conhecimento, desde a concepção do objeto, aos resultados do trabalho e à sua aplicação" (Minayo, 1994, p.14-15). 
Assim, a análise de conteúdo partiu dessa busca "insistente" dos temas que poderiam estar por vir nas diversas e repetidas leituras do material transcrito ("unidades de registro"). Estabelecendo e elegendo alguns temas mais comuns encontrados nos textos, partiu-se para a sua contextualização, inserindo-os na realidade. No terceiro momento, identificou-se nos resultados as categorias relacionadas à reflexão da pesquisa, desenvolvendo o processo de discussão do trabalho.

Utilizou-se entrevistas semi-estruturadas como instrumental investigativo através de um roteiro de questões que subsidia a interlocução com o sujeito. A utilização da entrevista semi-estruturada dar-se-á através do diálogo e é parte essencial desta fase do trabalho. Para Sarmento (1997) a entrevista é uma conjunção entre técnica e arte, deve basear-se no princípio da valorização e aceitação da pessoa humana e tem como principal característica necessária o conhecimento e habilidade. Pretendeu-se reconstituir e interpretar o pensamento do sujeito envolvido na pesquisa.

O conteúdo do roteiro de questões foi elaborado de acordo com as indagações preliminares dessa pesquisadora quando iniciou a investigação sobre Ética em pesquisa. O roteiro tem o papel de conciliar aquilo que os pesquisadores, de forma geral, indagam sobre o assunto e associá-lo com questões ainda não traçadas por sua reflexão; assim, é um instrumento facilitador que favorece as descobertas, as surpresas e as questões antes já reconhecidas.

O questionário aplicado baseou-se em: conhecimento do perfil do participante (idade, sexo, experiência); identificação do significado sobre 
pesquisas envolvendo seres humanos; experiência em pesquisas com questionários e/ou entrevistas; o envolvimento com os sujeitos; a forma de aplicação dos questionários e/ou entrevistas; o perfil do público envolvido nas pesquisas (socioeconômico e escolaridade); o significado de trabalhar com grupos institucionalizados; questões sobre riscos para o participante; identificação sobre o conhecimento e o entendimento da normativa nacional; opinião sobre os CEPs; experiência em eventos sobre ética e definição do tema.

As entrevistas foram transcritas a partir das anotações e compreensão da pesquisadora, e cada uma recebe numeração que não corresponde com a ordem das entrevistas. Assim, para melhor visualização, os discursos são apresentados por: P1, P2 igual a participante 1, participante 2. As transcrições completas estão no Anexo 2 deste trabalho.

Os resultados com a discussão estão classificados por dados quantitativos e qualitativos.

A pesquisadora contatou os possíveis sujeitos que possuíam um perfil anteriormente estipulado quanto à suas experiências como pesquisadores, apresentando a proposta de participação na pesquisa e esclarecendo sua importância. Os sujeitos da pesquisa foram entrevistados pela própria pesquisadora e àqueles que concordaram em participar foi apresentado o Termo de Consentimento Livre e Esclarecido (Anexo 3) em duas vias, sendo uma da pesquisadora e a outra do participante.

Nesse momento de interlocução, o sujeito da pesquisa foi esclarecido sobre a preservação de sua imagem e identificação - visto que não 
necessitou de nenhuma identificação pessoal como: nome, filiação, endereço etc - e sobre seu direito de sair ou desistir da pesquisa em qualquer momento, sem que qualquer prejuízo ou dano derivassem dessa decisão.

Após esses esclarecimentos iniciou-se a entrevista em sala reservada no mesmo ambiente de trabalho do sujeito participante. Não foi feito o uso de gravador, pois a pesquisadora preferiu o método de anotação das respostas na medida em que o diálogo se desenvolvia.

Não foram constatadas previsões de riscos ou desconfortos físicos, psicológicos, sociais e/ou morais para o sujeito da pesquisa, apesar de haver, no roteiro de questionário, perguntas que apontam para a área dos valores morais e/ou éticos. Não foi intenção analisar e identificar o "ético e o não-ético", e sim conhecer o discurso do participante a respeito do tema.

A pesquisa de campo foi somente iniciada após aprovação do Protocolo de Pesquisa por parte do Comitê de Ética em Pesquisa da Faculdade de Odontologia da USP (Anexo 4). 


\section{RESULTADOS E DISCUSSÃO}

A discussão neste mesmo capítulo tem o objetivo de possibilitar ao leitor um cenário de interpretação lógica e crítica do real; forma encontrada para expor os discursos simultaneamente æ̀s reflexões deles originadas.

A descrição dos resultados deste trabalho apresenta-se de duas formas:

1- Quantitativas: organizadas em forma de tabelas, gráficos e discussão;

2- Qualitativas: onde se utilizou o método de transcrição do discurso no intuito de auxiliar o processo de discussão e de identificação das categorias de análise.

Conforme indicado em Material e Método, a amostra composta por 28 participantes são identificados por numerais. Em cada subtítulo encontra-se o tema da pergunta questionada ao participante ou a categoria apropriada a questão.

Nas transcrições serão encontradas o símbolo de reticências em grande parte das falas, que representa momentos onde o pesquisado silenciava, æ̀s vezes pensando, outras vezes buscando palavras para ser compreendido e, em outras não encontrando respostas. 
Sobre estes momentos Maruyama (1999, p.94-95) evidencia o processo de conflitos que existe no momento da interlocução entre o pensar e o expressar: "... ao se expressar, o locutor projeta seus conflitos básicos através de palavras, silêncios, lacunas, dentro de processos na sua maioria inconscientes."

Em cada temática da pesquisa foram recortadas algumas falas consideradas mais relevantes para a discussão. Os resultados foram avaliados como se segue:

\subsection{Dados quantitativos}

\subsubsection{Perfil dos participantes}

Após avaliação dos resultados, apresenta-se o perfil dos participantes em três categorias: distribuição por faixa etária e sexo; por titulação e exercício de docência; por departamentos. 
5.1.1.1 Distribuição por faixa etária e sexo

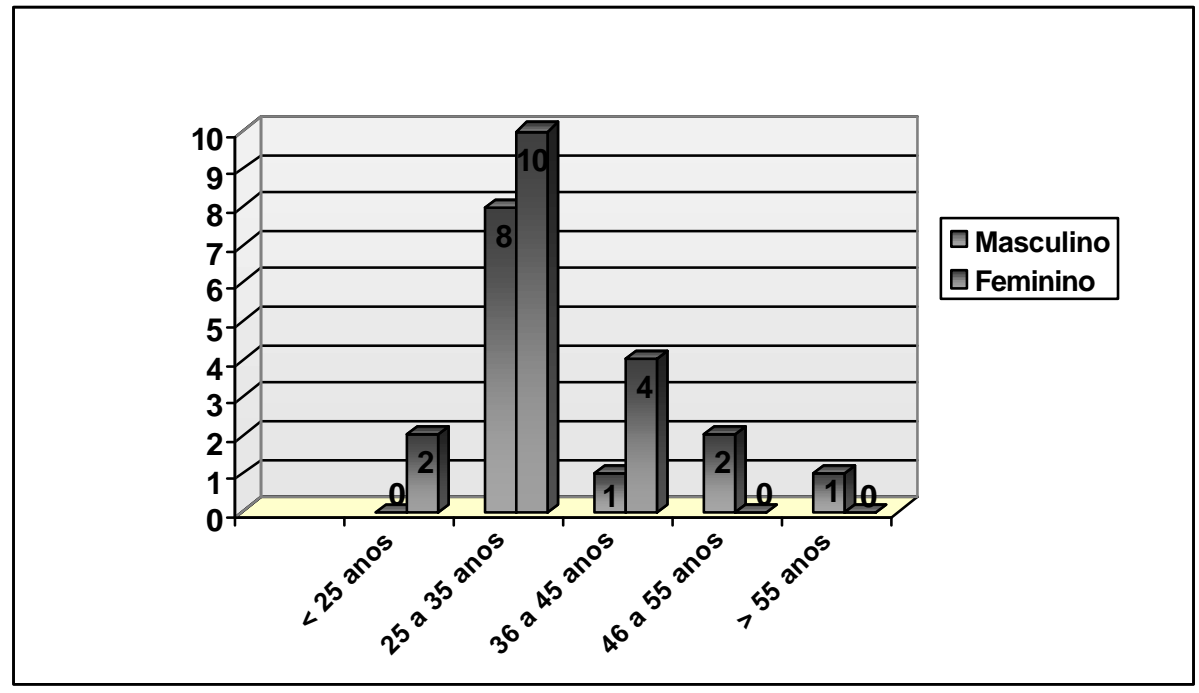

Gráfico 5.1- Distribuição por faixa etária e sexo(em n. absolutos)

De acordo com o Gráfico 5.1, dos 28 participantes, 12 (43\%) eram do sexo masculino e 16 (57\%) do sexo feminino. Foi observado uma parcial paridade com o predomínio entre 25 e 35 anos (18 participantes).

5.1.1.2 Distribuição por experiência em pesquisa e exercício de docência

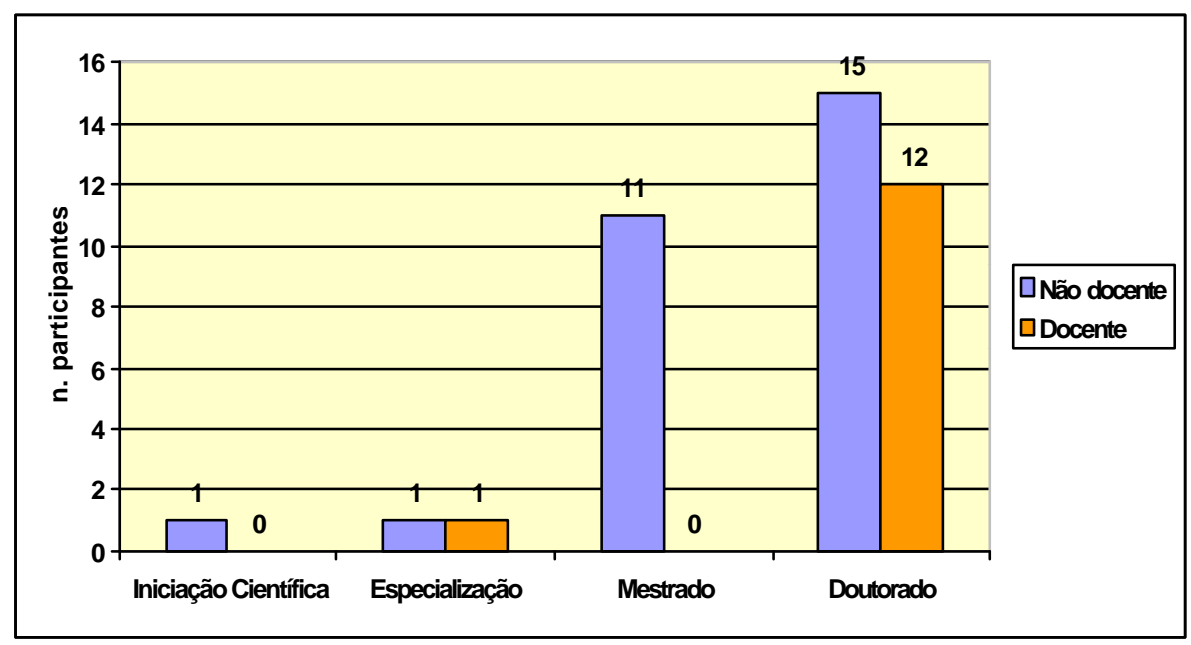

Gráfico 5.2 - Participantes com experiência em pesquisa que exercem atividade de docência 
Em relação a área dos pesquisados, foram entrevistados cirurgiõesdentistas que possuíam alguma experiência em atividades de pesquisa (mestrado, doutorado e docência).

Conforme Gráfico 5.2, dos 28 participantes, 11 eram mestrandos; 15 doutorandos; 1 com especialização e 1 que participou de iniciação científica.

Chama atenção o fato de que os que eram mestrandos não exerciam a docência (11), enquanto 12 doutorandos e aquele que tinha título de especialização (1) a exerciam.

\subsubsection{Distribuição dos participantes por departamento}

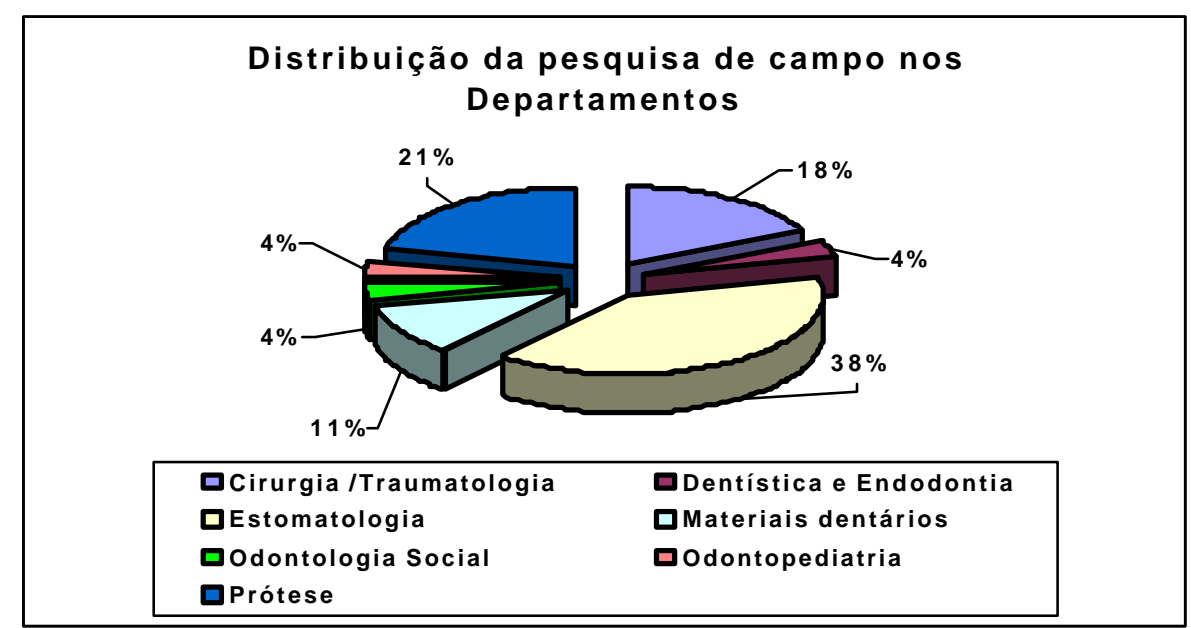

Gráfico 5.3 - Representação dos participantes por Departamentos

Com o objetivo de captar as diferentes visões sobre ética em pesquisa foram contemplados os sete departamentos da FOUSP. Embora o departamento de estomatologia apresente um valor mais significativo (38\%) deve-se considerar que este envolve um número maior de disciplinas e não 
foi enfoque deste trabalho fazer a distribuição igualitária por departamentos e sim, abranger todos eles. Conforme observado no Gráfico 5.3.

5.1.2 Utilização dos instrumentais questionários e/ou entrevistas nas pesquisas

Dentre os colaboradores, 15 informaram que já utilizaram questionários em suas pesquisas. Quanto as entrevistas, 17 também afirmaram fazer uso de entrevistas em algumas de suas pesquisas.

O uso de questionários e/ou entrevistas nas pesquisas da saúde já é uma rotina; o que vale ressaltar é que muitas vezes esses instrumentais não são considerados técnicas que precisam do mesmo rigor científico adotado no método dos trabalhos. Sendo assim, a utilização deles merecem atenção e estudo, pois não é possível para fazer uso aleatoriamente; há uma razão e justificativa lógica para optar sobre os variados tipos de questionários e modelos de entrevista.

Embora tal informação não corresponda com a essência deste trabalho é importante ressaltar que, conforme Sarmento (1997, p.287):

"a entrevista é sempre uma relação face-a-face entre duas ou mais pessoas, sendo que a diferenciação em seu uso é dada pela maneira e a intenção de quem a pratica mas, reconhecendo que é uma relação de distância e envolvimento, conhecimento e ação, pensamento e realidade, interação e conflito, mudar e ser mudado." 
Enquanto Nogueira-Martins (2001, p.50) diz:

"A grande vantagem da entrevista sobre outras técnicas é que ela permite a captação imediata e corrente da informação desejada, praticamente com qualquer tipo de entrevistado e sobre os mais variados tópicos. Permite correções, esclarecimentos e adaptações que a tornam eficaz na obtenção das informações desejadas."

E Gil (1989) destacou que ela é uma forma de interação social, sendo que muitos autores a consideram como a "técnica por excelência na investigação social”.

Por outro lado, ainda conforme Gil (1989), o questionário constitui como uma das mais importantes técnicas disponíveis para obtenção de dados em pesquisa social, porém enfoca algumas de suas limitações, como por exemplo: excluir pessoas analfabetas; não oferecer garantia que as pessoas o devolverão, dentre outras.

Considerar estes fatos na realização do planejamento de pesquisa é a mínima garantia para obter um método adequado e relevante para o estudo.

5.1.3 Perfil do público envolvido nas pesquisas

Neste item a abordagem é a percepção e identificação do participante sobre os sujeitos de pesquisas. "Quem são eles?"

\subsubsection{Público}


Tabela 5.1 - Público envolvido nas pesquisas dos participantes

\begin{tabular}{l|c|c}
\hline Público & $\mathbf{n}^{\mathbf{0}}$ & $\%$ \\
\hline Pacientes & 19 & $68 \%$ \\
Alunos & 3 & $11 \%$ \\
Funcionários & 0 & $0 \%$ \\
Colegas de profissão & 6 & $21 \%$ \\
Pacientes de outras instituições & 2 & $7 \%$ \\
Detentos & 0 & $0 \%$ \\
Outros & 3 & $11 \%$ \\
Não respondeu & 5 & $18 \%$ \\
\hline Total de participantes* & $\mathbf{2 8}$ & $\mathbf{1 0 0 \%}$ \\
\hline
\end{tabular}

* múltiplas entradas, participantes que responderam 02 ou mais alternativas.

A maioria do público envolvido nas pesquisas dos participantes são de pacientes, 19 responderam que os sujeitos de suas pesquisas são efetivamente pacientes da instituição de ensino e pesquisa ao qual estão vinculados, o que equivale a $68 \%$ da amostra. As outras alternativas de público eram: Colegas de profissão com o total de $6(21 \%)$ participantes que já fizeram pesquisas; 3 (11\%) já fizeram com Alunos; 2 (7\%) com Pacientes de outras instituições; 3 (11\%) optaram pela categoria Outros e 5 (18\%) não responderam este quesito justificando-se por não terem realizado pesquisas com seres humanos. Verifica-se estes dados na Tabela 5.1.

Segundo o Regimento Interno da FOUSP (1993) uma de suas finalidades enquanto instituição de ensino e pesquisa é prestar serviços a comunidade através de tratamentos odontológicos; por sua vez, os usuários- 
pacientes colaboram com o ensino e a pesquisa na Faculdade participando de pesquisas, ensaios clínicos e casos didáticos.

O fato em si parece ser de fácil compreensão, até por que as pesquisas na Odontologia devem, de acordo com o Regimento Interno em seu Art. $2^{\circ}$, no item III, "incentivar, promover e coordenar projetos de pesquisa indispensáveis ao desenvolvimento da Odontologia e æ̀s necessidades da saúde bucal da comunidade;" daí infere-se a necessidade do estudo com seres humanos, inseridos na área da saúde bucal.

Os pacientes são considerados como público essencial, e muitas vezes os mais disponíveis a participarem das atividades de pesquisa na Odontologia.

\subsubsection{Condições socioeconômicas e escolaridade}

Buscou-se verificar qual seria a percepção dos pesquisadores a respeito das condições socioeconômicas dos sujeitos de pesquisa e nível de escolaridade. A importância do tema refere a possibilidade de reflexão do pesquisador sobre quem realmente é o "meu" sujeito de pesquisa e em qual realidade ele está inserido, questão talvez, à vezes desapercebida no universo do exercício da ciência.

Para tanto, foi utilizado como referencial de classificação socioeconômica o estudo da Graciano et al. (1999) que desenvolveu os estratos sociais de classificação socioeconômica como:

- Baixa Inferior (BI): estrato social considerado quando o número de pessoas residentes na mesma moradia é de 04 a 06 pessoas, 
escolaridade do chefe familiar estar no nível do Ensino Fundamental 1 incompleto, ocupação profissional caracterizada por trabalho assalariado, empregados domésticos ou inseridos no mercado informal (trabalho por conta própria ou volantes), habitação cedidas e precárias, e a faixa de renda familiar fica de 1/aa 2 salários mínimos.

- Baixa Superior (BS): estrato social considerado quando o número de pessoas residentes na mesma moradia é até quatro pessoas, escolaridade do chefe familiar estar entre o nível do Ensino Fundamental 2 até o Ensino Médio, ocupação profissional em trabalho assalariado, habitação própria porém em condições não satisfatória, a renda familiar pode estar na média de 2 a 4 salários mínimos ou de 4 a 10 salários.

- Média Inferior (MI): estrato social considerado quando o número de pessoas residentes na mesma moradia é também de até quatro pessoas, escolaridade do chefe familiar varia entre o Ensino Médio completo até Ensino Superior completo ou incompleto, ocupação profissional em trabalho assalariado administrativo, de caráter técnico-científico ou profissional liberal autônomo, habitação própria, renda familiar entre 10 a 15 salários mínimos.

- Média (M): estrato social considerado quando o número de pessoas residentes na mesma moradia é de até quatro pessoas, escolaridade do chefe familiar é de nível do Ensino Superior, ocupação profissional em trabalho profissional liberal autônomo, moradia própria, renda familiar entre 15 a 35 salários mínimos. 
Nos estudos de Graciano et al. (1999) existia ainda a inclusão de mais dois estratos sociais, o MS - Média Superior e A - Alta, que não foram utilizados nesta pesquisa.

Esta pesquisadora explicou resumidamente aos participantes os níveis acima citados de classificação socioeconômica.

Os resultados desta avaliação socioeconômica não são precisos, pois não foi realizada diretamente com os sujeitos de pesquisa; mas o objeto de interesse é apenas ressaltar a percepção dos participantes desta pesquisa sobre o tema.

Além desta classificação socioeconômica questionada ao participante, foi também associada, separadamente, a percepção sobre o nível de escolaridade de seus sujeitos de pesquisa. Mesmo havendo na classificação um informe sobre escolaridade, considerou-se importante ressaltar este item fora da classificação socioeconômica.

Tabela 5.2 - Percepção dos participantes quanto às condições socioeconômicas dos sujeitos de pesquisa

\begin{tabular}{l|c|c}
\hline Estrato social & $\mathbf{n}^{\mathbf{0}}$ & $\%$ \\
\hline Baixa Inferior & 8 & $29 \%$ \\
Baixa Superior & 6 & $21 \%$ \\
Média Inferior & 5 & $18 \%$ \\
Média & 2 & $7 \%$ \\
Não respondeu & 7 & $25 \%$ \\
\hline Total & $\mathbf{2 8}$ & $\mathbf{1 0 0 \%}$ \\
\hline
\end{tabular}


Assim, de acordo com a Tabela 5.2, obteve-se como resultado para uma parte do grupo, 8 (29\%) participantes, que o nível socioeconômico de seus sujeitos de pesquisa são de classificação Baixa Inferior, a classificação Baixa Superior foi opção de 6 (21\%) participantes, 5 (18\%) optaram pela Média Inferior e Média com 2 (7\%) pessoas. Não responderam esta questão $7(25 \%)$ participantes, alguns por não ter contato direto com as pessoas nas pesquisas, outros por que desejaram não opinar devido não terem claro a percepção.

Portanto, a distribuição da classificação socioeconômica de acordo com os participantes desta pesquisa não é muito evidente, porém, estabelecendo um parâmetro de comparação entre as duas classes mais baixas, a Baixa Inferior com a Baixa Superior soma-se o resultado de 14 pessoas que optaram por estas classificações. O que é viável dizer, que mais de $50 \%$ do grupo opinaram que o nível social dos sujeitos de pesquisa era baixo (Baixa Inferior e Baixa Superior). 
Tabela 5.3 - Percepção dos participantes quanto à escolaridade dos sujeitos de pesquisa

\begin{tabular}{l|c|c}
\hline Nível de escolaridade & $\mathbf{n}^{\mathbf{0}}$ & $\%$ \\
\hline Analfabeto/Semi-analfabeto & 2 & $7 \%$ \\
Ensino Fundamental 1 & 11 & $40 \%$ \\
Ensino Fundamental 2 & 2 & $7 \%$ \\
Ensino Médio & 4 & $14 \%$ \\
Ensino Superior & 3 & $11 \%$ \\
Não respondeu & 6 & $21 \%$ \\
\hline Total & $\mathbf{2 8}$ & $\mathbf{1 0 0 \%}$ \\
\hline
\end{tabular}

Sobre o nível de escolaridade, os participantes acreditam que a maioria de seus sujeitos de pesquisa possuíam escolaridade até o Ensino Fundamental 1, 11 (40\%) participantes optaram por este nível, do Ensino Fundamental 2 foram 2 (7\%) opinantes, do Ensino Médio 4 (14\%) acharam que era o perfil de seus sujeitos e 3 (11\%) escolheram o nível de Ensino Superior. Ainda encontrou-se 2 (7\%) participantes que optaram pelo o nível Analfabeto ou Semi-analfabeto e 6 (21\%) pessoas não responderam esta questão, conforme Tabela 5.3.

A escolaridade está realmente associada com as condições sociais das pessoas, quando o indivíduo está inserido em contexto social caracterizado de inúmeras dificuldades de condições de habitação, inserção ou exclusão no mercado de trabalho, por sua vez, fica evidente a dificuldade de continuidade da educação escolar. 
5.1.4 Apreciação dos projetos de pesquisa

Foi interrogado aos participantes sobre quais comissões e/ou instituições eles devem submeter seus projetos de pesquisa.

A totalidade das respostas pautou-se na apresentação de seus projetos aos Comitês de Ética em Pesquisa da instituição aos quais estavam vinculadas as pesquisas. Em alguns casos também foi informado da apreciação de seus projetos a departamentos de pesquisa e orientadores.

Dos 28 participantes apenas 1 não apresentou seu projeto de pesquisa ao CEP e justifica informando que sua pesquisa não envolveu seres humanos. Os outros 27 participantes informaram que submetiam o projeto ao CEP, sendo que alguns também apresentavam à Comissão de Pesquisa Hospitalar (1), outros a órgãos de fomento à pesquisa (2), Comissão Científica (1) e orientadores (2).

\subsubsection{Conhecimento da Resolução № 196/96}

Este item informa sobre o conhecimento dos participantes a respeito da Resolução no 196/96:

Dos participantes, 19 afirmaram não conhecer ou reconhecer o documento, 9 informaram que conheciam.

Esta informação traz bastante preocupação para os que dedicam seus trabalhos à ética em pesquisa, pois se sabe que o documento comentado estar em vigor há seis anos e desde então os comitês de ética foram criados e institucionalizados nas diversas unidades de pesquisa no 
Brasil, desenvolvendo trabalho inclusive de disseminação da Resolução no 196/96 entre os pesquisadores.

\subsubsection{Participação em eventos sobre Ética em Pesquisa}

Procurou-se verificar a participação dos depoentes quanto a eventos sobre Ética em Pesquisa. Apenas 06 participantes negaram ter experiência em algum evento relacionado ao tema, os outros 22 pesquisados afirmaram ter participação em eventos na área. Este dado permite afirmar que Ética em Pesquisa não é tema desconhecido aos entrevistados. Quanto aos tipos de eventos foram citados como: palestras, congressos, aulas, seminários, cursos e reuniões.

Este resultado confrontado com a questão anterior, sobre o conhecimento da Resolução, sugere uma contradição, pois se a maioria já participou de algum evento sobre ética em pesquisa, como não tiveram contato com o documento que regulamenta tal questão?

O fato é que é preciso dedicar tempo e interesse no conhecimento da Resolução; o enfoque nos eventos deve voltar-se ao informativo. O pesquisador precisa buscar o conhecimento a partir de suas necessidades; quando realiza pesquisas com seres humanos faz-se imprescindível este conhecimento. 


\subsection{Dados qualitativos}

\subsubsection{Pesquisa envolvendo seres humanos}

A partir deste item serão apresentados alguns relatos da entrevista sob o interesse de ilustrar os discursos dos participantes; para tanto, conforme material e método, cada participante será identificado por 'P” e número, exemplo: Participante 1 = $\mathbf{P 1}$.

Inicialmente o participante se surpreendia com a pergunta: "O que você considera pesquisa envolvendo seres humanos?"; parecendo não compreender o por quê de uma questão tão óbvia. Em alguns casos foi necessário um maior esclarecimento para o participante sobre o significado e importância daquela questão, ou seja, qual o seu olhar e sua compreensão sobre pesquisa envolvendo seres humanos. Neste momento foi possível perceber a dificuldade de esclarecer sem imediatamente responder pelo pesquisado.

Com relação a pergunta citada, foram destacados partes das entrevistas, como se segue:

P15: "Qualquer tipo de material de origem do ser humano, seja saliva, cabelo... dados coletados de pacientes..."

P20: "Um simples questionário já está envolvendo seres humanos... os dados, as informações de pessoas, tudo isso já é pesquisa com seres humanos... biópsia nem se fala..." 
P25: "Toda pesquisa que envolva direta ou indiretamente os indivíduos... os órgãos, células, entrevistas, tudo isso é pesquisa com seres humanos."

Tais relatos evidenciam a concepção dos participantes que o termo "pesquisas envolvendo seres humanos" refere-se a toda pesquisa que envolva direta ou indiretamente o ser humano. Este entendimento está de acordo com a definição da Resolução no 196/96, Cap.II, Inciso 2 (1996, p. 15):

"- pesquisa que, individualmente ou coletivamente, envolva o ser humano, de forma direta ou indireta, em sua totalidade ou partes dele, incluindo o manejo de informações ou materiais."

A abrangência do conceito da Resolução reforça a necessidade do pesquisador compreender que não somente quando utiliza pessoas diretamente, mas também e não menos importante, seus dados, órgãos e informações, dentre outros, é entendimento essencial que pode colaborar com a postura ética do pesquisador, e trata-se, sim, de "Pesquisa com Seres Humanos".

A seguir apresentam-se discursos que se diferenciam da abordagem anterior onde os participantes justificam o que, para eles, não se caracteriza como "pesquisas envolvendo seres humanos".

P13: “... Vai até um limite de tolerância... dados de pessoas não é pesquisa com seres humanos..."

P21: "Apenas quando há participação de seres humanos, pessoalmente." 
P27: "Pesquisa que trabalha com boca, questionário não são pesquisas envolvendo seres humanos... é só quando envolve o ser humano diretamente."

P28: "São pesquisas que envolvam o ser humano diretamente... não acho que dente é pesquisa com seres humanos."

As respostas foram mensuradas de acordo com a identificação de termos ou perspectivas que divergissem claramente da proposta da Resolução no 196/96. Assim, nos discursos acima encontram-se citações que sugerem contradições de conceitos, uma vez que concebem pesquisa envolvendo seres humanos como aquela que engloba o indivíduo na sua parcialidade de visão; como por exemplo: as afirmações que não consideram pesquisas envolvendo seres humanos àquelas que trabalham com dentes, dados de pessoas, boca e/ou questionários.

Fazendo ponte com Galitesi (2000), o fato de ser o dente nossa estrutura mais rígida, morta, mineralizada, com dureza que resiste ao tempo, ácidos e até incinerações, mas que, ainda assim guarda em seu interior ligação com a fluência e sensibilidade dolorosa, enfim, íntima ligação com a vida.

Dessa forma, como é possível um pesquisador da Odontologia não compreender que dentes, prontuários etc façam parte do contexto humano?

"Saiba que o CD não deve sequer dar a um aluno de Odontologia, (....) um dente extraído de um paciente, mesmo que tenha sido um procedimento necessário. Se o fizer sem seguir algumas normas, estará infringindo os princípios éticos e poderá ter muita dor de cabeça 
no âmbito judicial. O material biológico - no caso, um simples dente - é humano e, mesmo que descartado, pertenceu um dia a alguém. (....) nos dias de hoje, muitas metodologias não são mais toleradas, ao se realizar experimentos" (Silva, 2001, p.393).

Neste sentido, confirma-se a necessidade do pesquisador estar atento e informado sobre os limites e possibilidades na pesquisa.

"Pode-se dizer que o órgão dental é a expressão mais perpetuada e sensível da espécie... nosso mais fiel representante do corpo físico“ (Galitesi, 2000, p.34).

5.2.2 Processo de envolvimento do sujeito nas pesquisas

Sobre o processo de envolvimento do sujeito da pesquisa, pretendese identificar como se dá à abordagem do pesquisador para com o sujeito pesquisado, ou seja, de quê forma o sujeito é convidado a colaborar com as pesquisas.

A nomenclatura "paciente" é utilizada para não sugerir, nem influenciar o participante sobre visão de sujeito de pesquisa, além do mais, "paciente" é o termo mais associado a participantes de pesquisa no universo da área da saúde, uma vez que estes costumam ser paralelamente pacientes dos pesquisadores.

Sobre o termo "paciente", Gauderer (1991) destacou sua origem como uma "postura obsoleta". A pessoa doente deveria ter paciência para esperar o retorno de sua saúde, sua recuperação, porém não é este o entendimento 
de alguns grupos que geralmente compreendem o termo como o indivíduo que deve ter paciência pela demora de ser atendido, pelo descaso em alguma consulta, pela ausência de vaga para o tratamento etc.

"Não é fácil ser paciente! A pessoa se sente exposta, agredida fisicamente e emocionalmente, não só pela doença como também pelo profissional de saúde, que apalpa, aperta, injeta, corta, subtrai esperanças, cria restrições ou dita normas. A pessoa doente sente inquietações, angústias, medos, frustrações, inseguranças, inferioridades, incapacidades, raivas ou outras emoções. Onde irá despejar ou colocar essas sensações?" (Gauderer, 1991, p.15).

Compreender o universo de conflitos em que o paciente geralmente está pode ser o primeiro passo para vê-lo enquanto sujeito de direitos. Fortes (1998) colaborou com esse pensamento dizendo que todo indivíduo quando está na posição de paciente deve ser cuidado para o restabelecimento de sua saúde, e não como instrumento para satisfazer a ciência, profissionais de saúde, interesses industriais e/ou comerciais.

A direção do olhar para o outro pode ter várias faces; uma pessoa pode ser para outras um sujeito de pesquisa; um paciente; um indivíduo; um ser humano ou qualquer outra designação de papéis: "o subordinado", "o coitado", "o ignorante" etc. Atributos esses que correspondem a "estigma"; palavra associada àcicatriz, uma marca dada à pessoa com razões muitas vezes desconhecidas pela própria.

"As rotinas de relação social em ambientes estabelecidos nos permitem um relacionamento com 'outras pessoas' previstas sem 
atenção ou reflexão particular. (....) quando um estranho nos é apresentado, os primeiros aspectos nos permitem prever a sua categoria e os seus atributos, a sua 'identidade social'(....)" (Golfman, 1998, p.12).

Na intenção de identificar qual a ênfase mais preponderante nas falas dos participantes sobre o envolvimento dos sujeitos nas suas pesquisas, optou-se em classificar em três categorias: associação com o tratamento odontológico; preocupação com o consentimento e contribuição para a ciência. De acordo com os grifos apontados nos relatos pela pesquisadora se sobrepõe a ênfase em determinada categoria; sendo então o primeiro valor considerado pelos pesquisadores no estímulo do envolvimento de seus sujeitos.

Alguns não fizeram pesquisas diretamente com seres humanos, neste caso era solicitado uma suposição, caso fizessem em algum momento.

\subsubsection{Associação com o tratamento odontológico (benefício direto)}

Para esta categoria reservou-se os relatos em que se identifica a associação do estímulo para participarem da pesquisa com o tratamento odontológico, ou seja, os pesquisadores enfatizam que a forma de envolver seus sujeitos de pesquisa nos trabalhos está relacionada com o tratamento paralelamente advindo.

Isto se dá rotineiramente nas áreas em que as pesquisas são voltadas para área clínica (pesquisas na saúde), onde em conseqüência do 
tratamento odontológico o paciente pode oportunamente estar colaborando com alguma pesquisa, embora não seja obrigado a fazê-lo.

Em alguns depoimentos também encontra-se o entendimento do pesquisador sobre esta associação; acreditam que fornecer um tratamento em razão da pesquisa é o estímulo maior para o consentimento do paciente, um benefício direto.

P15: "Bom, não precisei informá-los, já havia um trabalho em andamento... eles já estavam motivados para ajudar... era uma coleta (....) e umas perguntas... “

P24: "Os pacientes eram encaminhados para avaliação... explicava a pesquisa, o objetivo, sobre o questionário e apresentava o termo de consentimento..." Questionado se os pacientes tinham noção sobre a diferença que aqueles procedimentos eram de uma pesquisa ou confundiam com procedimentos do próprio tratamento, respondeu: "Não, mesmo explicando eu tenho certeza que eles imaginavam que aquelas perguntas faziam parte da rotina do tratamento."

P28: “... Você precisa de (....)? Quer fazer?... O benefício era (....) não essa "coisa" de comitê de ética. “

Observação: O benefício oferecido era exatamente o serviço que o paciente veio buscar, ou seja, não há benefício quando o usuário vai receber aquilo que teria direito enquanto paciente e não como sujeito de pesquisa. 
O paradigma presente nestes discursos revelam o acesso do pesquisador ao pesquisado, ou seja: "Como o pesquisador concebe este outro?"

O "outro" aqui mencionado, completamente destituído de identidade, caracteriza-se por ser "sujeito" com necessidades de algum tipo de tratamento odontológico, com identidade coletiva de "paciente" e perfil de "caso" ideal para as pesquisas. O pesquisador às vezes esquece que este "paciente-caso" trata-se de uma "pessoa". O caminho percorrido para encontrar o sujeito que lhe interessa está nos setores de atendimento/tratamento, pressupondo o fácil acesso para os pesquisadores que trabalham nessas áreas.

Em contrapartida, o significado de "sujeito" não acaba por aí, sua representação enquanto "paciente" é apenas um aspecto do ser humano; um momento em que a maioria das pessoas já passaram ou passarão por esta experiência, inclusive os profissionais de saúde.

Para Guattari citado por Sposati (1995, p.66) "o sujeito constitui sua identidade no encontro com o outro, isto é, na diferença."

Não pretende-se aqui esgotar a temática, ao contrário, inicia-se um processo de reflexão do lugar do sujeito nas pesquisas, tanto o sujeito pesquisado quanto o sujeito pesquisador.

Vale lembrar a noção de pessoa de Xavier (2000, p.220) com base na Filosofia, ele diz que " a pessoa se constitui em um fim em si mesmo, porque é um centro de liberdades capaz de transcender-se e superar-se continuamente." 
5.2.2.2 Preocupação com o Consentimento (formal)

Em outros depoimentos a ênfase do envolvimento com os sujeitos pesquisados é com o processo de obtenção do consentimento. Esta preocupação é de extrema importância, porém o envolvimento com o sujeito de pesquisa se faz anterior a este processo. O consentimento é parte de um diálogo que quase sempre é realizado ao final de um encontro, quando se estabelece uma relação.

P1: "Pediria autorização, convidaria..."

P3: "Faria através de perguntas e respostas... São pacientes, assim, informava sobre a pesquisa, fazia a entrevista e apresentava o Termo de Consentimento."

P4: "Falando com os pacientes... primeiro o consentimento verbal, depois o formal, que é esse Termo que você me apresentou... faria o convite."

A necessidade de formalizar uma relação é própria do ser humano. Nas famílias com o casamento; no emprego com o contrato de trabalho; nas amizades e relacionamentos amorosos; no exercício de cidadania; nas atividades rotineiras de um consumidor, dentre outras, constróem contratos para o estabelecimento de algum acordo. Esses acordos são necessidades naturais do homem, e são eles o referencial da ação que pode ser exercida. Contrato assim compreendido é resultado de uma relação que antes de tudo supõe um encontro. 
"Relacionamento faz parte da vida do ser humano e está presente sempre que ocorre um encontro entre duas pessoas ou mais. Aliás, está presente inclusive quando nos encontramos sozinhos, pois não podemos nos esquecer do relacionamento do indivíduo consigo mesmo; com suas potencialidades, limitações, defeitos e qualidades, entre outros. Podemos inclusive, conjeturar que o relacionamento que o indivíduo mantém consigo mesmo, como ele se vê e se coloca perante a sociedade está diretamente ligado a forma como se relaciona com outras pessoas. (....) Todo encontro provoca mudanças" (Alves, 2000, p.06).

Ao apresentar a questão do envolvimento com os sujeitos de pesquisa pretendia-se saber como se dava esta relação, uma vez que para alguns participantes, o consentimento torna-se a base dessa relação.

\subsubsection{Contribuição para a Ciência}

Outros relatos apresentam como o fator de mais influência no envolvimento com os sujeitos de pesquisa a "conscientização" quanto a sua contribuição para a Ciência.

Esta é uma razão há muito tempo utilizada para justificar pesquisas. A importância da ciência para humanidade é de inestimável valor, porém há de se ressaltar que a mesma ciência que constrói já destruiu populações em massa; portanto, o paradigma da busca do conhecimento não termina com 
esta questão; Araújo (1999) afirmou que uma pesquisa é ética desde o início e não se tornará ética porque os seus resultados científicos são valiosos.

P11: "Caso eu fizesse falaria da importância do trabalho para o futuro da ciência... melhora de qualidade de vida..."

P13: "Conscientizando o paciente que o trabalho [pesquisa] poderia ajudar $\underline{\text { no futuro... " }}$

P27: "Mostrando que sua participação poderia trazer resultados positivos... "

A ciência e a ética são lados de um mesmo percurso, não são antagônicos, para realizar pesquisas científicas é necessário o conhecimento do método e da técnica, mas também, de ética.

Além disso, também é necessário "mudar de lugar", estar ao lado do outro é um grande começo para iniciar uma relação, que precisamente deve ser solidária. Sobre esta relação Amaral citada por Alves (2001, p. 27) colaborou dizendo:

"Sofrer juntos nos leva a sair do 'alto' e a estar ao 'lado', horizontalizando a relação. Nos leva a solidariedade (....) Nos arranca do 'patamar superior' e nos faz estar junto na dimensão do sofrimento (....) no faz (....) buscar saídas ou superações (....) é a própria solidariedade (......"

Assim, obter o consentimento de seu sujeito de pesquisa sob a alegação de prover o "bem" para a ciência, por si só, não é suficiente. 
Encontrar pessoas dispostas a colaborarem com pesquisas na área da saúde é tarefa razoavelmente simples devido ao natural "lócus" desses estudos; os hospitais-escola, faculdades, institutos promovem assistência à saúde e paralelamente também pesquisas, e neste caminho deparam-se com o paciente - sujeito de pesquisa. Isto pode explicar porque há ausência nos discursos de citações que indiquem dificuldades de acesso ao sujeito, e portanto, também há uma certa despreocupação de como aproximar-se dele.

"Não podemos, entretanto, aceitar uma ciência que se afaste, radicalmente, de toda iniciativa de caráter moral. Nem tudo que é possível, deverá ou será feito, mais dia, menos dia " (Lima, 2000, p.569).

O caminho da aproximação com a pessoa parece estar no compartilhar, ou seja, estar junto. Este entendimento colabora com a construção de uma relação horizontal; estar ao lado independente do tipo de relação, seja profissional ou pessoal. Preocupar-se com o outro e não usálo, são sentimentos de valores morais que fazem parte da essência humana, resgatá-los é de fundamental importância.

5.2.3 Abordagem com questionários e / ou entrevistas

Na tentativa de promover uma discussão sobre a questão anterior, a abordagem dos sujeitos participantes, e de compreender como eram 
empregados os questionários e entrevistas, suscitou-se uma nova indagação: como eles aplicavam questionários e entrevistas?

P2: “Explicação oral, a finalidade da pesquisa e apresentação do Termo de Consentimento."

P18: Questionário: “Esperava o paciente, pedia o consentimento e pedia para preencher o questionário.”

P23: Questionário: “Expliquei a pesquisa e pedi para o paciente preencher as questões de acordo com a sua compreensão..."

Entrevista: "Informava a proposta da pesquisa e fazia perguntas direcionadas a pesquisa."

P24: "As perguntas eram diretas... tivemos o cuidado de adequar a linguagem mais comum p/que eles entendessem... eles achavam que fazia parte de uma avaliação do tratamento."

Os relatos seguiram-se de forma metodologicamente adequados, pautados na ação de informação - explicação - consentimento (nem sempre nessa ordem); em sua maioria a abordagem vincula-se a importância da participação dos sujeitos para a pesquisa dentro dos interesses do pesquisador.

Para Araújo (1999) a obtenção do consentimento do sujeito da pesquisa deve ser pautado na informação, vontade e competência. $\bigcirc$ indivíduo precisa ser esclarecido sobre os objetivos, justificativa, procedimentos, desconfortos, riscos e benefícios, das alternativas de métodos, além da necessidade de manifestar sua vontade em participar do 
estudo, expressando-a também no Termo de Consentimento Livre e Esclarecido. A competência está vinculada a capacidade do indivíduo em dar seu consentimento (grifo nosso).

Sobre a necessidade da informação Gauderer (1991, p.11-12) enfatizou que uma pessoa bem informada terá mais possibilidades de escolhas e mais livre se sentirá para tomar decisões, e uma pessoa com liberdade afasta a ignorância, a desinformação.

"A informação é a base da decisão, do julgamento e da ponderação. É com ela que aprendemos e podemos nos questionar, levantar novas hipóteses e possibilidades, diminuindo consequentemente a margem de erro e aumentando os acertos. A informação soma, acrescenta, e portanto faz crescer. (....) A informação é a base da autonomia, da independência, do conhecimento e da cultura."

5.2.4 Situações de "riscos" na aplicação de questionários e / ou entrevistas

A utilização de questionários e / ou entrevistas nas pesquisas na área de Odontologia são também usuais. O que parece não estar definido entre os pesquisadores é a reflexão sobre este instrumental enquanto possível causador de danos, desconfortos, constrangimentos e riscos aos que se submetem a sua aplicação, isto é, os sujeitos de pesquisa.

Os entrevistados confundiram a questão do risco para o sujeito da pesquisa com os "riscos" inerentes ao insucesso da pesquisa, como por exemplo, o pesquisador não conseguir dados confiáveis, o que comprometeria o bom andamento da pesquisa. Assim, muitos são os casos 
em que o pesquisador aponta que poderá existir "riscos", não para o sujeito participante mas para a pesquisa e consequentemente, para ele mesmo. Nas respostas há uma série de afirmações que indicam que o pesquisador julga que pode ser vítima de algum dano.

A palavra desconforto é bastante citada nas falas dos participantes, porém essa freqüência é devido a menção da pesquisadora responsável por este trabalho ao traduzir para o participante a questão anunciada. Sendo ela mencionada, foi utilizada como suporte para os participantes concordarem ou não sobre a existência de "riscos" para os sujeitos pesquisados quando são entrevistados ou respondem a um questionário.

O que parece também ser visualmente sentido é que para os participantes da pesquisa a palavra risco é muito forte, geralmente é associada à riscos físicos, a relação entre vida e morte. Algumas vezes foram citadas possibilidades de riscos morais, emocionais e sociais.

Apresenta-se o texto sob três categorias: Riscos para o sujeito da pesquisa, Riscos para o pesquisador/pesquisa e Ausência de riscos.

5.2.4.1 Riscos para o sujeito da pesquisa

Dos participantes que concordaram existir riscos para o sujeito pesquisado na aplicação de questionários e entrevistas há presente nos discursos as palavras: intimidação, vergonha, constrangimento, humilhação, medo, problemas emocionais, moral, valores, discriminação, invasão de privacidade, ofensas, exposição, ansiedade e receio. 
Em todas as palavras, sem contar com desconforto e risco, há um sentido pejorativo que pode indicar as possíveis conseqüências que o conteúdo de um questionário e / ou entrevista pode trazer para o indivíduo participante.

Atentar para este fato não é tarefa de fácil precisão para quem está localizado do outro lado da mesa, o "entrevistador". Deve-se isso ao objeto de preocupação, seu resultado. Porém, no pensar sobre o tema surgem várias confirmações de riscos.

P6: "Acredito que tenha riscos. Desconforto... talvez pela obrigação de ter que responder, pode trazer lembranças que não gostaria... lembrança ruim... porém são poucas essas que causam riscos... A entrevista é pior que o questionário pois ela intimida as pessoas."

P12: "O paciente pode se sentir envergonhado, constrangido, humilhado, dependendo das questões. É um desconforto emocional e psicológico. E um risco para a pesquisa é os dados não serem verídicos, ou seja, os pacientes não falarem a verdade."

P20: "Existe algum tipo de desconforto relacionado a quebra do sigilo... $\underline{o}$ paciente fica com medo... pode-se fazer perguntas que trás a tona problemas emocionais do paciente... um dia, na pesquisa do IBGE, a entrevistadora perguntou para uma pessoa que era portadora de esquizofrenia se era casada e por causa disso a pessoa teve uma crise pois nunca casou... não sabemos a priori o que a pessoa tem de problemas." 
Risco é toda a probabilidade de dano. Seguindo este conceito associa-se dano à todas as palavras citadas no início de discussão deste item: intimidação, vergonha, constrangimento, humilhação, medo etc. Porque não dizer que causar esses sentimentos é provocar um dano a pessoa? Em razão de estar contribuindo com um estudo, não pode ser aceitável que o participante retorne a sua vida habitual com um saldo de ter que tratar dos sentimentos ora advindo daquela sua experiência vivida. $\mathrm{O}$ que talvez seja razoável é o pesquisado saber anteriormente ao seu consentimento, sobre os possíveis danos que possam vir a lhe ocorrer e, é claro, ser o pesquisador responsável a salvaguardar a integridade do seu sujeito, sendo capacitado em orientar, encaminhar e dar subsídios para manter a estabilidade da "normalidade" ora encontrada na pessoa.

De acordo com essa compreensão, denota-se o pensamento de Sawaia (2000, p.15) sobre a dificuldade de entendimento de que a pesquisa social é um experimento com seres humanos:

"A maioria das pesquisas em Ciências Humanas usa o homem como informante dos dados a serem analisados(....) Todos eles afetam o sujeito, não apenas os experimentos, mas as entrevistas e os questionários construídos dentro do maior rigor científico, pois o levam a refletir, recordar, criar expectativas, estabelecer relações."

É neste sentido que revela-se risco possível de ser mensurado quando o instrumental é questionário ou entrevista. Levá-los em conta no processo de elaboração de questões destes instrumentais é também exercício ético fundamental. 
5.2.4.2 Riscos para o pesquisador/pesquisa

Nas respostas sobre riscos, alguns participantes associaram sobre o que poderia prejudicar ou interferir nos bons resultados de suas pesquisas, dentre elas constam: dados inverídicos, dados incorretos, respostas erradas, mentiras. A visão destes depoentes é que o participante (sujeito pesquisado) pode provocar algum dano àpesquisa.

P11: "Não acredito que possua riscos... há riscos para o pesquisador como por exemplo, responderem algo errado, prejudicando o resultado da pesquisa."

P15: " Acredito que não tenha riscos... há apenas para o pesquisador... as respostas podem não serem verídicas."

P21: "Para mim há risco para o pesquisador... podem mentir..."

Neste contexto, ao se por em pauta a questão do risco inerente às pesquisas, os entrevistados reagiram muito mais preocupados com as conseqüências para eles e menos, com as conseqüências para o sujeito da pesquisa.

\subsubsection{Ausência de riscos}

A preocupação de não causar um dano de caráter físico a indivíduos é antiga e íntima na área da saúde, os experimentos médicos são exemplos preponderantes neste assunto. A Odontologia fundamentalmente realiza intervenções de natureza física buscando restaurar a saúde bucal. 
Ao falar de riscos então, fica inevitável sua ligação com a dimensão física, porém, prever apenas os prejuízos de natureza física é também não conceber o ser humano como indivíduo social, apropriado de cultura, valores e crenças e de emoções.

P4: "Não vejo possibilidade de riscos, desde que o questionário elou a entrevista estejam bem elaborados... boa formulação de perguntas... depende da abordagem do pesquisador."

P16: "Não tem riscos... desde que a participação seja espontânea."

P26: "Não há. Algumas pessoas podem sentir-se constrangidas..."

Ainda nestes depoimentos há controvérsias, uma vez que em um dado momento afirmam possibilidades de riscos e na mesma resposta não o consideram, parece ser uma sugestiva incompreensão sobre o significado de risco para o sujeito pesquisado.

A Resolução no 196/96 (1996), cap. II, define:

Risco da Pesquisa:

"- possibilidade de danos àdimensão física, psíquica, moral, intelectual, social, cultural ou espiritual do ser humano, em qualquer fase de uma pesquisa e dela decorrente" (grifo nosso).

Dano associado ou decorrente da pesquisa:

"agravo imediato ou tardio, ao indivíduo ou à coletividade; com nexo causal comprovado, direto ou indireto, decorrente do estudo científico." 
Os conceitos que a Resolução apresenta sobre risco e dano são os referenciais escolhidos para a reflexão deste item. Quando pergunta-se sobre risco, imediatamente o profissional da área da saúde, associa àdano físico, porém poucos atentam para o prejuízo que se pode causar na esfera psíquica, moral, intelectual, social, cultural ou espiritual da pessoa.

\subsubsection{O significado de trabalhar com grupos institucionalizados}

A questão que iniciou o debate deste tema era: "O que você acha de trabalhar com detentos?". E a justificativa desta questão era tentar iniciar uma discussão sobre indivíduos institucionalizados, os chamados grupos "expostos a condicionamentos específicos ou à influência de autoridade"que a Resolução nำ196 (1996) trata em seu capítulo IV, sobre o Consentimento Livre e Esclarecido, item 3-b:

" Nos casos em que haja qualquer restrição à liberdade ou ao esclarecimento necessários para o adequado consentimento, deve-se ainda observar:

b) a liberdade do consentimento deverá ser particularmente garantida para aqueles sujeitos que, embora adultos e capazes, estejam expostos a condicionamentos específicos ou àinfluência de autoridade, especialmente estudantes, militares, empregados, presidiários, internos em centro de readaptação, casas-abrigo, asilos, associações religiosas e semelhantes, assegurando-Ihes a inteira liberdade de 
participar ou não da pesquisa, sem quaisquer represálias;" (grifo nosso).

Assim, tratou-se de acrescentar um ponto de discussão para estimular o participante a desenvolver seu pensamento sobre sujeito e sujeito em condições especiais.

No andamento das entrevistas, essa foi uma questão que causou estranheza aos participantes. Muitas vezes questionada do por quê desta questão, a pesquisadora discorria em um diálogo com o participante sem tentar levá-lo ao foco que intuitivamente gostaria: a obtenção do consentimento. Assim, foi percebido em grande parte das falas um direcionamento da questão ao assunto da segurança e do medo. Estas são palavras extremamente presentes nas respostas dos participantes, onde associavam rotineiramente sobre o resguardo físico próprio e dos seus.

Deste modo, os relatos foram subdivididos para melhor compreensão do leitor, em três categorias:

1- Medo e/ou segurança: aqueles que mencionaram enfaticamente que não trabalhariam com este grupo devido ao receio de ser agredido ou por resguardo físico; ou trabalhariam apenas caso houvesse segurança;

2- Sujeitos em condições especiais: os que citaram e reconheceram - grupo como sujeitos institucionalizados, que possuíam autonomia relativa;

3- Outra categoria: os relatos em que os participantes não citavam reconhecê-los como grupos especiais, porém em alguns casos 
afirmavam que poderiam trabalhar desde que possuíssem o consentimento dos detentos; nesta mesma categoria também há alguns relatos que não mencionam consentimento.

Os grifos nas transcrições representam o foco de identificação da categoria ao qual foi classificada.

\subsubsection{Medo / segurança}

P3: "Não entraria em contato pessoal pois teria medo, talvez trabalhasse com dados deles: prontuários, etc."

P9: "Teria receio... por medo talvez, porém acho que é um grupo mais fácil de controle para o acompanhamento da pesquisa... acho que eles não estão presos inocentemente, portanto fizeram algo de errado e assim, não vejo problema algum eles darem suas contribuições para o sucesso da ciência participando de pesquisas, assim como devem trabalhar, produzir sua própria alimentação."

P18: "Não trabalharia em razão de serem detentos... por segurança."

O sentimento de medo presente nestes relatos refere-se a preocupação com a integridade física. Esta reação é associada a realidade dos grandes centros de detenção, principalmente na cidade de São Paulo, onde a mídia rotineiramente informa crises do sistema penitenciário inseridos no contexto de violência, agressões e falta de segurança, como por exemplo: as rebeliões que utilizam reféns. Neste sentido compreende-se o 
receio do pesquisador, além disso, de acordo com Vieira \& Hossne (1998, p.54) o pesquisador atualmente teme acusações de abuso quando fazem experimentos com detentos, evitando assim, os estudos com esta população.

5.2.5.2 Sujeitos em condições especiais

Neste item encontram-se afirmações que indicam o conhecimento do pesquisador quanto a possibilidade dos sujeitos possuírem uma "autonomia restrita", ou seja, em razão de estarem confinados, subordinados a certas regras de comportamento, o detento poderá consentir sua participação nas pesquisas em função de decisão de "outros", institucional, e não vigorando a sua própria vontade.

P5: "Neste caso existe um problema ético: eles fazem parte de um grupo especial para fazer pesquisa, ou seja, talvez estariam sendo obrigados a participarem da pesquisa."

P22: "Não trabalharia... é uma população confinada... estariam servindo como cobaias ... seriam obrigados a participar... eles devem ser tratados como todos os seres humanos... e também não concordaria que eles tivessem diminuição de pena por estarem participando de pesquisa, não acho justo!"

P25: " Do ponto de vista ético é a mesma coisa que "grupos especiais", $\underline{\text { são }}$ também sujeitos de pesquisa especiais, eles não têm autonomia plena." 
Por "autonomia restrita" entende-se princípio ético onde o indivíduo é privado de exercer seu livre arbítrio, sua autodeterminação, ou seja, sem condições ou capacidade de fazer escolhas. É o exemplo do detento, privado de sua liberdade por força de Lei.

Vieira \& Hossne (1998, p.54) declararam que os prisioneiros podem e devem participar de pesquisa enquanto participante, desde que seja sua vontade e eventualmente que possa trazer algum benefício direto relacionado ao seu problema de saúde.

Apesar de encontrar discursos que reconhecem o detento como indivíduo com direitos e deveres, os participantes deste estudo não atentaram sob o aspecto geral do questionamento: 0 indivíduo institucionalizado, subordinado à uma determinada instituição ou relação de poder.

É reconhecido no interior das atividades de ensino e pesquisa a efetiva participação de alunos nas pesquisas propostas pelos seus professores. Será que este "sujeito-aluno" tem a liberdade plena de recusar sua participação?

A preocupação com a informação e consentimento são verdades explícitas na leitura dos discursos. A compreensão da capacidade autônoma do indivíduo em participar é um assunto não enfrentado pelos participantes.

\subsubsection{Outra categoria}

Por "outra categoria" pretendeu-se apresentar as opiniões de alguns entrevistados que concebiam os detentos como sujeitos de pesquisa iguais a 
qualquer outra pessoa, sem considerar os limites de autonomia desta específica população.

P10: "Não haveria nenhum problema, para mim é normal como qualquer paciente. "

P14: "O Estado que estaria oferecendo? Do jeito que você falou ( $A$ Penitenciária oferecendo detentos para participarem de pesquisa) até parece que eles não são pessoas, parece que está oferecendo um número $X$ de gados para pesquisar. Não concordo com isso. Não importa quem for, presos, doentes mentais, o que for... são pessoas e elas têm o direito."

O que é relevante mostrar é a diversidade de valores imbuídos nos discursos sobre os sujeitos de pesquisa. Nas falas, no silêncio são encontrados significados do que é importante ser enquanto sujeito colaborador de pesquisa. A sua autonomia? O benefício direto? $\mathrm{O}$ voluntariado? Ou a consciência de ajudar o progresso da ciência?

\subsubsection{Importância da Resolução № 196/96 para as pesquisas}

Após a pergunta que trata sobre o conhecimento ou não do participante sobre a Resolução ํo196/96, a pesquisadora apresentava o nome formal da Resolução (Diretrizes e normas regulamentadoras de pesquisas envolvendo seres humanos) e estimulava um diálogo sobre seus principais objetivos. Deste modo e após informação esclarecedora do tema, 
foi perguntado ao participante sobre suas considerações a respeito deste documento, ou seja, para ele, quê importância teria?

Portanto, destacam-se três papéis da referida Resolução nas respostas dos pesquisados: A Resolução enquanto reguladora das ações, associada como representação de Lei, o Papel Regulador / Legal. Outro papel é o de cunho norteador para o pesquisador atribuindo-lhe um Papel Orientador / Educativo. E o Papel Restritivo / Limitativo, que pode ser confundido com o "Regulador / Legal", porém para este trabalho, assume-se a definição de "Restritivo" aquilo que cerceia algo não por ocasião de Lei, mas por necessidade de controle, uma intervenção limitativa.

\subsubsection{Papel Regulador / Legal}

Os discursos aqui apresentados dimensionam a primeira visão que a Resolução no 196/96 traz para os pesquisadores em geral, um regulamento, uma Lei que deve ser cumprida.

P4: "Tem sentido legal, normativo... não pode ser interpretado da mesma maneira, depende de cada contexto... sua avaliação depende de vários fatores... Esta Resolução deveria ser adaptada à realidade. “

P12: " Acho que me ajudou... na preparação do meu projeto de pesquisa, porém não me sinto capacitado para avalia-la... é uma lei, um regulamento e como todas as leis deve ter algo há questionar... "

P14: "Tudo que fazemos tem que ter uma ética... moramos numa sociedade e vivemos de acordo com determinadas regras, normas... é normal. Existe 
norma para tudo. Acho importante termos esta resolução... se não fosse assim não existiria nenhum controle. “

Sob a lógica da hermenêutica o documento enquanto Resolução trata-se de regulamento nacional que na ausência de Lei superior, é normativa Legal que deve ser seguida pelos pesquisadores no Brasil. $\mathrm{O}$ próprio preâmbulo da Resolução identifica os principais documentos internacionais e nacionais de ordem jurídica e normativa que a fundamenta e legitima como norma brasileira referente à pesquisa envolvendo seres humanos.

As afirmações destes relatos são consonantes com o termo regulador que the é denominado. Ressalta-se porém, que a origem da questão ao pesquisado está voltada ao papel desta Resolução.

As opiniões elencadas neste item abordam o papel Regulador/ Legal enquanto primeira visão de análise. Esta é uma das características principais que denotam à Resolução uma obrigação a ser cumprida, uma exigência burocrática.

\subsubsection{Papel Orientador / Educativo}

Há também aqueles que identificam o documento citado enquanto guia orientador para as pesquisas. Neste perfil, a Resolução torna-se colaboradora do pesquisador no processo de elaboração e execução das pesquisas. 
P5: "Ela contribui... orienta os procedimentos que devemos tomar."

P6: "Para mim o papel da resolução é de orientador. Muitas vezes você está envolvido na pesquisa e não percebe algo que seja importante para a reflexão ética. “

P22: "É um orientador... já li, acho que serve como um guia de orientações... muitas vezes me ajudou até nos meus atendimentos com pacientes... “

O papel educativo que é atribuído à Resolução está associado às recomendações de ordem ética que o documento apresenta em todo o seu texto.

Quando o homem exerce uma atividade há muito tempo já preconizada como habitual e nasce uma nova forma de exercê-la, a transformação não é instantânea, ela faz parte do processo interno e externo onde o homem está inserido, e ele precisa acompanhar fase a fase o momento desta aprendizagem, até um dia, tornar-se rotina. Assim, considera-se a função educativa da Resolução.

"Hábito é pura e simplesmente uma qualidade adquirida (autoadquirida e livremente desenvolvida) que facilita e aperfeiçoa a ação e aperfeiçoa também o próprio homem" (Lauand, 1997, p.10). 


\subsubsection{Papel Restritivo / Limitativo}

Ao sobrepor a Resolução um papel restritivo, o pesquisador aponta sua "sentença": a Resolução é um documento que está dissociado da minha realidade e necessidade prática. Este é um julgamento bastante presente nos relatos dos participantes.

P9: " Acredito que esta Resolução colaborou para a diminuição de pesquisas clínicas... ninguém quer mais fazer pesquisa clínica. Acho também que trouxe uma necessidade de discussão ética. Há um fato preocupante: a restrição. Para outras pessoas, não para mim pois não utilizo seres humanos em minhas pesquisas, mais é visto como mais uma burocracia. “

P27: "Dependendo do tipo de pesquisa, veio para contribuir... por outro lado, veio para complicar as pesquisas mais simples. "

Para alguns, o documento tem o seu "valor", no entanto, ele também preconiza um espaço que até então não era conhecido ou delimitado. O espaço da reflexão ética. Por isso, é visto em muitos campos, o cerceador de pesquisas.

A restrição que apontam à Resolução é de ordem burocrática. Parece ser angustiante o fato de debruçar-se no estudo de mais um documento. Em todos os espaços da atividade humana o fator limite é considerado como um obstáculo a ser superado. Contudo, os limites fazem parte da esfera social no homem; eles são criados e aperfeiçoados pelos próprios homens, muitas vezes para garantir uma harmonia na coletividade. 
5.2.7 Os Comitês de Ética em Pesquisas - CEPs

Sobre os Comitês de Ética em Pesquisa, muito tinha-se a falar. Os participantes não somente discorreram sobre o tema, mais "euforicamente" levantaram bandeiras, fizeram seus juízos, denunciaram modelos, sugeriram, reprovaram e aprovaram. E se emocionaram com suas próprias conclusões.

Há em grande parte dos discursos um apelo; neste sentido compreende a necessidade da intrínseca relação entre CEP e Pesquisador.

Dedicam ao Comitê julgamentos prévios, e de ordem arcaica associando-o à "fiscais da ética", "o perseguidor", ou " o pai descuidado", dentre outros adjetivos que o nomeiam.

O processo de avaliação dos protocolos de pesquisa dos CEPs foi um tema bastante citado pelo pesquisador. Uns criticam a competência do avaliador, outros o tempo das respostas, e outros o nível alto de exigências. E muito há para discutir e refletir.

Para apreciação desses discursos foi estabelecido dois enfoques significativos para análise. O primeiro refere-se ao Processo de Avaliação dos protocolos de pesquisa, pois como anteriormente foi citado, este foi um tema efusivamente narrado pelos participantes. $O$ segundo, mais abrangente, refere-se aos manifestos de Julgamento de Valor que os participantes apresentaram a respeito de CEPs. 


\subsubsection{Processo de avaliação}

Os entrevistados apresentaram uma série de protestos relacionados ao processo de avaliação dos protocolos de pesquisa. Logicamente impulsionou o diálogo à rotina de uma das atividades que é de maior interesse para os pesquisadores: a aprovação de seu protocolo de pesquisa.

P7: "Acho que há uma falta de consenso... falta critérios de avaliação entre os CEPs. Há demora nas respostas (parecer), falta de uma unidade, uma direção única. A existência de um CEP sem dúvida é positiva."

P18: "Discordo das avaliações... o avaliador deve ser profissional específico de ética em pesquisa... Acho necessário ter um comitê centralizado... o cirurgião-dentista não tem condições de avaliar ética em pesquisa. "

P27: " Não tem o por quê de ficar voltando para lá e para cá. $\underline{A \text { avaliação }}$ deveria ser mais "branda" quando envolve apenas questionário... Não deveria ser necessário passar no CEP quando não envolve seres humanos diretamente. "

O que é crucial para o pesquisador, é a agilidade e praticidade na tarefa de avaliação de seus protocolos, pois muitas vezes estão sob pressão do cronograma: pressão do curso, das instituições que financiam, pressão pessoal etc.

A agilidade tão esperada depara-se com o "Parecer Científico". quando o resultado deste parecer é positivo o pesquisador terá uma consideração sobre o CEP, partindo de sua experiência. Quando o resultado 
da avaliação do comitê pautar-se na necessidade de revisão do protocolo o pesquisador terá outras considerações. O entendimento sobre o trabalho dos CEPs muitas vezes limita-se ao resultado de avaliação de suas pesquisas (aprovado, reprovado ou deve ser revisto).

Além de tudo, o receio de absorver o estigma do trabalho "não ser ético" é de extremo significado para qualquer pesquisador.

É necessário compreender que não apenas os CEPs, mas também os pesquisadores devem ter responsabilidade e dedicação na revisão ética das pesquisas. São responsabilidades bilaterais.

Estes dois sujeitos: pesquisador e $\underline{\text { CEP }}$ devem aproximar-se. Estabelecer uma relação que proporcione o diálogo.

"Alcançando este relacionamento de menos enfrentamento e de mais confiança e aliança, é provável que se consiga caminhar com passos firmes e largos na transformação do dever do bem no prazer do bem, ou seja, do dever de respeitar o sujeito de pesquisa no prazer de respeitá-lo e acolhê-lo como pessoa titular de dignidade" (Zoboli, 1999, p.21).

\subsubsection{Julgamento de Valor}

Em toda atividade humana é reconhecida uma ou mais categorias que expressam os valores. Nos discursos sobre os CEPs os participantes conceituam, discursam e exprimem seus pensamentos demonstrando quais são os valores atribuídos aos comitês. 
P9: "É um trabalho sério. A dinâmica de trabalho é lenta, avaliação dos projetos é lenta... deveria orientar melhor os pesquisadores que direcionam as pesquisas na Faculdade, ou seja, deveria chegar mais próximo dos professores que coordenam e orientam linha de pesquisa. “

P17: " Acho que eles pecam pelo excesso... são questões pessoais, individuais... eles impedem pesquisas que são epidemiológicas... tem que ser revisto as pessoas que fazem parte do CEP... se são realmente qualificadas. “

P28: "O comitê tem o seu valor, pois muitas vezes, em nome da ciência fizeram muita coisa errada, porém você é que deve assumir as conseqüências... não precisava existir se cada um assumisse o seu papel de responsabilidade... na odonto eles só enxergam a boca e não o ser humano como um todo..."

Os depoimentos sob os dois enfoques: processo de avaliação e julgamento de valor, se complementam e se confundem, ora discursando sobre as avaliações ora emitindo valores; a face do discurso (a aparência) é a expressão emitida pelos interlocutores, porém o outro lado do mesmo discurso (a essência) se expõe nas entrelinhas inevitavelmente sugestivas para uma ampla discussão.

Assim como um pai defende seu filho quando há alguma ameaça física, moral ou intelectual, o pesquisador também o faz com suas pesquisas. Eles exprimem seus sentimentos mais profundos na esfera da paixão e razão, pois é desta maneira que poderá justificar a sua “ criação”. 
Neste sentido, focaliza-se o sentimento de intolerância versus tolerância nas escalas de valores atribuídas aos CEPs. Ao mesmo tempo que é importante, necessário; para outros, não deveria existir CEPs. Assim são os discursos, uns incluem os CEPs nas suas rotinas de trabalho e reflexão; outros os excluem alegando impropriedade.

"A tolerância é uma conquista no caminho em direção àsolidariedade, este laço recíproco que une pessoas como co-responsáveis pelo bem umas das outras. $\mathrm{E}$ não se pode negar que, respeitadas as especificidades e limites das funções de cada um, CEP e pesquisador compartilham a responsabilidade ética pelo bem do sujeito de pesquisa" (Zoboli, 1999, p.21).

\subsubsection{0 que é Ética em Pesquisa?}

Solicitar que conceituem ética em pesquisa sob o seu parecer foi ponto de abertura, e não de finalização, para um amplo e expressivo caminho de encontro com este sujeito: o sujeito pesquisado, que por sua vez, é pesquisador.

Apresenta-se a seguir, todas as respostas obtidas desta questão. A transcrição integral dos depoimentos julga-se necessária, pois poderá favorecer ao leitor uma maior liberdade interpretativa.

Os grifos buscam destacar observações da pesquisadora. 
P3: "Usar o bom senso, não fazer absurdos... visar os dois lados: a pesquisa e o sujeito."

P4: "Preservar as condições fisiológicas, morais do sujeito do estudo... ser claro e transparente com o sujeito, tudo isso dentro de um contexto. Sugere a limitação do espírito de pesquisa."

P5: "Sugere refletir até que ponto vou tirar um benefício do outro... até que ponto devo olhar para mim (a pesquisa) e não para o outro (o sujeito)."

P6: "Depende da formação das pessoas... se a pessoa tem na prática a ética como fundamento de suas atitudes, seja na família, no trabalho ou em pesquisas... será natural sua prática ética nas pesquisas. Essas coisas de respeitar o outro... até onde vai a sua liberdade..."

P7: "O conceito é amplo. Envolve respeito ao ser humano e a relação com o objetivo de produzir a melhoria da qualidade de vida dos seres humanos... tudo que ferir, não só fisicamente mas também socialmente os indivíduos, não seria ético... não considerar os fins sem considerar os meios. “

P8: "É contribuir com a Ciência... é preciso utilizar seres humanos mas devese ter o cuidado de não expor este indivíduo... sempre consciente do que se faz."

P9: "É ter uma postura moral coerente com o sujeito da pesquisa... não favorecer nenhum grupo da pesquisa... preocupar-se em trazer benefícios para a Ciência sem prejudicar o sujeito da pesquisa."

P10: "É um modo como abordar o paciente ... você orientar o paciente sobre a necessidade do tratamento... não criticar outros profissionais... garantir o sigilo das informações ao paciente... cumprir com o planejamento prévio." 
P11: "É fazer a pesquisa com clareza... sem omitir dados... sem omitir riscos ou danos."

P12: "É aquilo que você não faz para chegar aos seus objetivos... abrir mão de alguns objetivos para não ter que passar por cima dos seus princípios e valores... abrir mão de objetivos po ética... não ir contra os meus princípios..."

P13: "Fazer sua pesquisa sem prejudicar ninguém."

P14: "Seria um conjunto de valores... antes de tudo seria a moral própria da pessoa... ética é próprio da pessoa, assim você cria um conjunto de valores... o que você pode ou não fazer... isso tudo se chama ética."

P15: "Fazer algo com algum benefício, claro, sem prejudicar ninguém."

P16: "Toda vez que faz uma pesquisa que não prejudica o indivíduo que está colocando na pesquisa... seja ser humano, animal..."

P17: "Fazer uma pesquisa que tenha benefícios... esclarecer muito bem o sujeito da pesquisa e segundo: ele deve concordar..."

P18: "Ter consciência que aquilo que você está fazendo trará mais

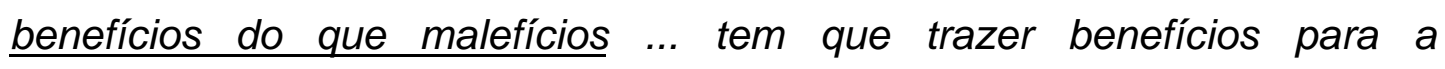
sociedade..."

P19: "Não prejudicar! Nem mentalmente, financeiramente, psicologicamente, biológica e fisicamente as pessoas.“

P20: "É um conceito abrangente o termo ética... para pesquisa acho que é você proteger o objeto da sua pesquisa a qualquer custo... este objeto são as pessoas, os sujeitos... tem que ter um benefício... sigilo também..."

P21: "Usar o ser humano sem causar dano e sempre com o consentimento." 
P22: "Respeito a vida humana e animal... obter dados realmente válidos para melhorar a qualidade de vida... tanto do homem quanto a do animal."

P23: "Coletar os dados com boa metodologia e interpretá-los realizando conclusões de acordo com os dados obtidos... ou seja, sem manipulação de resultados.“

P24: "A possibilidade de fazer pesquisa que seja efetivamente buscando o bem para o indivíduo. “

P25: "Pensar não só no benefício que o resultado vai trazer para a população em geral, mas também nos possíveis prejuízos que pode trazer para os sujeitos envolvidos. "

P26: "São todas as regras, normas sobre ética sem que prejudique o paciente... e os resultados devem ser utilizados para o fim proposto. Não submeter o paciente à pesquisas que não tragam contribuição para a ciência."

P27: "Fazer pesquisa sem prejudicar o paciente... não modificar a proposta do trabalho“.

P28: "Usar o paciente como um meio, mas oferecer algo concreto. Dar algum benefício, como a prótese para um desdentado, por exemplo.“

Nas definições de ética em pesquisa apresentadas pelos participantes deste estudo surgem caminhos para algumas reflexões:

- Que lugar de valor encontra-se a ética na prática da vida do pesquisador?

- A ética da vida, do privado, difere da ética na pesquisa, do público? 
- Respeitar a vontade autônoma da pessoa, desejar não causar mal, oferecer benefício direto ao participante e contribuir com o avanço da ciência são pressupostos suficientes para o exercício ético? É correto fundamentar a decisão ética na parcialidade de um ou outro desses pressupostos?

Seria possível continuar elaborando mais perguntas sob o estímulo do conteúdo dos discursos apresentados na questão sobre ética em pesquisa. No entanto o desafio é tecer algumas considerações a respeito da questão.

De acordo com os referenciais primariamente percebidos na família e na sociedade o indivíduo vai elaborando seus preceitos éticos, que muitos vezes não são racionalmente pensados e sim, apreendidos das relações interpessoais.

Independentemente do lugar da ética na vida da pessoa existe a noção do que é ou não ético no pensamento humano. Sua representação pode ser percebida nas ações, nos gestos, na dinâmica do trabalho, no silêncio, nas expressões de todas emoções, nas palavras, nos versos, ou seja, em toda atividade humana, porém há de se salientar que isto "apenas" não determina o lugar da ética.

"A gênese das escolhas e alternativas de valor são indissociáveis da práxis; por isso são categorias objetivas e históricas. Os valores, instituídos pela intervenção primária do homem na natureza, estabelecem mediações entre o homem e o objeto. (....) Ao mesmo tempo, as ações são sempre orientadas por categorias de valor, em geral, por mais de uma" (Barroco, 2001, p.30-31). 
As experiências do indivíduo com o mundo social envolve uma série de mediações. O encontro com as necessidades práticas, com as normas de comportamento, com as atitudes imediatas, com as relações interpessoais e profissionais são paradoxos de enfrentamento da vida particular do indivíduo. É nesse contexto privado que a noção de ética começa a fluir no pensamento humano.

Marcos (1999) enfatizou que o núcleo da ética está na reflexão do conflito, pois é neste patamar que a ética se apresenta como possibilidade de ser categoria filosófica apropriada para refletir sobre os dilemas que surgem em conseqüência das relações.

As respostas dos participantes sobre a definição de ética em pesquisa configuram direta ou indiretamente, expressão da vida cotidiana de cada um, assim, imbuída de valorações que estão associadas à história e ao modelo social vivido.

A ética "privada" portanto não poderia estar dissociada da ética profissional; esta última aqui considerada não como o exercício dos códigos de ética mas como referencial de conduta, maneira pela qual exerce sua atividade profissional para com os outros.

As atividades do pesquisador frente àpesquisa, e sua ação ética são fundadas por seus princípios, crenças e modo de ver a realidade.

Os conteúdos que representam o discurso quanto a temática ética em pesquisa, em sua maioria, estão acompanhados de influências do modelo bioético principialista onde a autonomia, a beneficência, não-maleficência e justiça fazem parte dos referenciais dos pesquisados. 
Para alguns pesquisadores, a preocupação em não causar mal ao sujeito de pesquisa ou prover algum benefício direto a ele torna-se garantia essencial para uma postura ética. Quando indagados sobre ética, a resposta é fragmentada à concessão de algo (benefício) ou a "garantia" que não prejudicará o indivíduo. Em outros casos, é considerada a autonomia do participante como fundamental para garantir o exercício ético, assim, quando enfatizam que o indivíduo deve ser "voluntário" resumem este princípio a obtenção do Termo de Consentimento. Para outros relatos, é conferido o discurso da importância da colaboração do sujeito para o "progresso da ciência", modo de ver o participante enquanto objeto da ciência.

Denota-se uma necessidade de modelo pragmático que auxilie o pesquisador na conduta da sua pesquisa.

Finalizando esta tarefa, vale ressaltar a importância da relação, quando esta se fundamenta no reconhecimento da dignidade e identidade humana: relação do pesquisador com o sujeito de pesquisa; do profissional com o paciente; do homem com o homem.

A base do encontro é estar ao lado; conhecendo, sentindo e participando da rotina da vida àvida socialmente construída.

“Depende da formação das pessoas... se a pessoa tem na prática a ética como fundamento de suas atitudes, seja na família, no trabalho ou em pesquisas... será natural sua prática ética nas pesquisas (....)" (Relato de um dos participantes). 


\section{CONSIDERAÇÕES FINAIS}

Não é pretensão levantar conclusões precisas a respeito da análise e discussão dos resultados deste trabalho, mas instigar algumas proposições éticas que incentivem o debate, presente e futuro, entre o universo do pesquisador (o pesquisador, instituição de pesquisa e CEPs) com o mundo social (as pessoas e suas representações).

O perfil do público envolvido nas pesquisas da Odontologia, semelhante àárea médica, é de pacientes; os pesquisadores identificam os pacientes como pessoas caracterizadas por condições socioeconômica baixa e de escolaridade em torno do ensino fundamental. Assim, caracterizase um distanciamento social, profissional e pessoal do pesquisador para com o paciente. Seria recomendável promover aproximações que minimizem esta distância, que contribuam ao estabelecimento de relações mais humanizadas. Para isso, poderiam ser incluídas, na formação dos pesquisadores (pós-graduação), disciplinas do campo das Ciências Humanas que favoreçam o encontro das teorias sobre a pessoa humana e esta frente àsociedade. 
Também não é mais admissível conceber a ação de pesquisa na área da saúde sem o reconhecimento da normativa brasileira referente a pesquisas com seres humanos: a Resolução nº 196/96. O pesquisador pode fazer uso da Resolução inserindo-a no conjunto de documentos básicos que orientam a elaboração e avaliação da pesquisa. A Resolução, sob a ótica da parceria, contribui, acrescenta, orienta, compartilha e educa.

É prudente relembrar que dentes, saliva, DNA, são materiais biológicos de pessoas; os dados obtidos em anamnese, questionários, entrevistas fazem parte da informação que também diz respeito à pessoa. Há limites e possibilidades na intervenção investigativa com seres humanos, e compreendê-los é razão necessária para o exercício bioético.

O envolvimento dos sujeitos nas pesquisas deve basear-se no respeito àsua identidade e dignidade. O processo deste envolvimento dá-se pelo encontro dos dois lados: o "sujeito da pesquisa" e o "pesquisador". São ambos seres humanos que carregam histórias, emoções e objetivos que em algum momento coincidirão. A pessoa humana é a totalidade do ser, um universo de complexidades individuais, sociais e coletivas.

Quando do uso de questionários e/ou entrevistas, o pesquisador deve estar atento para questões que possam causar dano, prejuízos de efeitos morais, emocionais e sociais ao sujeito participante, assim como em qualquer pesquisa que envolva seres humanos. Isto dependerá do modo de 
abordagem, da capacidade técnica-científica do pesquisador e de sua atenção a todas as dimensões da pessoa humana, um complexo bio-psicosocial-espiritual.

Analisar os riscos é conhecer a probabilidade de dano que sua intervenção pode causar no indivíduo. Há que se ressaltar a possibilidade de muitos questionários suscitarem más lembranças, provocarem preconceitos de ordem religiosa, moral, sexual que acabam por comprometer a integridade da pessoa. O pesquisador precisa estar apto a reconhecer estas questões e capacitado para lidar com elas.

O estudante, o paciente, o empregado, presidiário, pessoas institucionalizadas podem sofrer coerção implícita ou explícita para dar seu consentimento; nas escolas de Odontologia também é encontrado este perfil de público, pessoas em situação de dependência; logo, faz-se necessário a reflexão ética do pesquisador.

A ausência do diálogo provoca uma série de conflitos nas relações humanas. Assim é também a relação CEP - pesquisador. Em um lado, encontram-se as angústias científicas, e, em outro, as dificuldades operacionais. Há que se estabelecer canais que favoreçam uma maior proximidade, que possam propiciar um diálogo entre pesquisador e CEP, pois o que parece acontecer é um sentimento de hostilidade para com o Comitê. O pesquisador preconcebe o CEP como portador de uma postura dogmática, cerceadora do seu produto; a "eticocrítica". Superar este patamar 
de distanciamento ainda é desafio para os CEPs e para os pesquisadores. É necessário um esforço bilateral. Os CEPs exercem prática educativa e de apoio que muitas vezes são mal interpretadas, tidas como autoritárias.

A distância do pesquisador da área das ciências da saúde com as ciências sociais fragiliza o conhecimento das teorias que fundamentam muitos dos preceitos bioéticos. O que de fato é essencial é a promoção dos saberes éticos que orientem os pesquisadores como parte integrante de sua formação científica.

Ética pode ser ensinada; ética pode ser aprendida. 
ANEXOS 


\begin{abstract}
ANEXO 1
UNIVERSIDADE DE SÃO PAULO FACULDADE DE ODONTOLOGIA PROGRAMA DE PÓS-GRADUAÇÃO EM DEONTOLOGIA E ODONTOLOGIA LEGAL PESQUISADORA: Luciana Maria Cavalcante Melo ORIENTADOR: Prof. Dr. Dalton Luiz de Paula Ramos
\end{abstract}

ROTEIRO DE QUESTÕES PARA ENTREVISTA

1- IDADE: 2-SEXO:

3- GRADUADO (A) EM:

4- EXPERIÊNCIA ANTERIOR DO PESQUISADOR / ÁREA DE PESQUISA:

( ) INICIAÇÃO CIENTÍFICA:

( ) ESTÁGIOS:

( ) ESPECIALIZAÇÃO:

( ) MESTRADO:

( ) DOUTORADO:

( ) DOCENTE:

5- O QUE VOCÊ CONSIDERA PESQUISAS ENVOLVENDO SERES HUMANOS?

6- NA PARTE DA COLETA DE DADOS/PESQUISA DE CAMPO DE SEUS TRABALHOS DE PESQUISA UTILIZOU EM ALGUM MOMENTO QUESTIONÁRIOS?
( ) $\operatorname{Sim}$
Quantas vezes utilizou?
( ) Não
Quantos Questionários aplicados?

\title{
6.1-E ENTREVISTAS?
}
( ) $\operatorname{Sim}$
Quantas vezes utilizou?
( ) Não
Quantas Entrevistas aplicadas?

7- DE QUE FORMA VOCÊ ENVOLVEU OS PACIENTES A PARTICIPAREM DAS SUAS PESQUISAS? (convidado/convocado...)

8- COMO FOI OU COMO VOCÊ PRETENDE APLICACAR OS QUESTIONÁRIOS E/OU ENTREVISTAS? DE QUE FORMA ABORDOU OU PRETENDE ABORDAR OS SUJEITOS DA PESQUISA:

Questionánios:

Entrevistas: 
9- QUAL O PERFIL DO PÚBLICO ENVOLVIDO NAS SUAS PESQUISAS?

( ) Pacientes:

( ) Alunos:

( ) Funcionánios:

( ) Colegas de profissão:

( ) Pacientes de outras instituições:

( ) Detentos:

( ) Outros:

9.1- AINDA SOBRE O PÚBLICO, QUE CONDIÇÕES SÓCIOECONÔMICAS E NIVEL DE ESCOLARIDADE VOCÊ ACHA QUE A MAIORIA DELES PERTENCEM?
( ) BAIXA INFERIOR / ( ) ANALFABETO ou SEMI-ANALFABETO
( ) BAIXA SUPERIOR / ( ) ENSINO FUNDAMENTAL 1
( ) MÉDIA INFERIOR / ( ) ENSINO FUNDAMENTAL 2
( ) MÉDIA
( ) ENSINO MÉDIO
( ) ENSINO SUPERIOR

9.2- O QUE VOCÊ ACHA DE TRABALHAR COM DETENTOS?

10- QUE STTUAÇÕES DE "RISCOS"PODE EXISTIR QUANDO APLICA-SE QUESTIONÁRIOS E/OU ENTREVISTAS?

11- QUANDO SEU PROJETO DE PESQUISA ESTÁ PRONTO A QUE COMISSÕES E/OU INSTITUIÇÕES VOCÊ DEVE SUBMETÊ-LO PARA ANÁLISE?

11.1- VOCÊ CONHECE A RESOLUÇÃO №196/96 DO CONSELHO NACIONAL DE SAÚDE? A QUE SE REFERE?

11.2- COMO VOCÊ VÊ ESTA RESOLUÇÃO EM RELAÇÃO AS SUAS PESQUISAS? (nesta questão tentar identificar o papel da Resolução para os pesquisadores: colaborador, parceiro, "mais uma burocracia", etc)

11.3- COMO VOCÊ VÊ O TRABALHO DOS CEPs?

12- JÁ PARTICIPOU DE ALGUNS CURSOS, AULAS, SEMINÁRIOS, CONGRESSOS E OUTROS SOBRE ÉTICA EM PESQUISA? QUAIS?

13- O QUE É ÉTICA EM PESQUISA? 
ANEXO 2

\section{TRANSCRICQÕES DAS ENTREVISTAS}

\section{QUESTÃO 5: O QUE VOCÊ CONSIDERA PESQUISAS ENVOLVENDO SERES HUMANOS?}

P1: "Toda pesquisa que envolva as pessoas... materiais de diagnóstico, Rxs, documentação de pacientes."

P2: "Trabalho com pessoas, células, DNA... partes do ser humano e o todo."

P3: "Quando na sua casuística vai incluir seres humanos... é a interação do pesquisador com seres humanos... quando utiliza-se coleta de dados, entrevistas, etc."

P4: "Pesquisa diretamente ligada ao problema, pessoas... estrutura óssea, partes."

P5: "Todo ser humano ou parte dele."

P6: "Qualquer tipo de pesquisa clínica ... ou com questionários, dados de seres humanos..."

P7: "Toda pesquisa realizada com pessoas objetivando melhorias da saúde... partes de seres humanos, assim como dados (documentação) de pessoas... qualquer material."

P8: "Com seres humanos... parte dele, como biopsia por exemplo."

P9: "Pesquisa que envolve pacientes e dados de pacientes, porém a avaliação, os critérios de avaliação deveriam ser diferentes: quando se utiliza de seres humanos diretamente e quando utiliza parte dele (indiretamente). O critério deveria ser mais rígido quando a pesquisa envolve seres humanos diretamente."

P10: "Levantamento de dados, prontuários até a utilização direta com pacientes... e animais."

P11: "...Quando uso algo da pessoa... desde a saliva, o organismo... até a própria pessoa... não dados estatísticos."

P12: "Assim como pessoas diretamente, dados, registros... e outros..."

P13: "... Vai até um limite de tolerância... dados de pessoas não é pesquisa com seres humanos..." 
P14: "Bom, seres humanos pode ser: ... pessoas "vivas"e pessoas "mortas"... os dados... parte do corpo. São duas áreas diferentes... qualquer procedimento precisa de uma permissão."

P15: "Qualquer tipo de material de origem do ser humano, seja saliva, cabelo... dados coletados de pacientes..."

P16: "A pesquisa que envolve contato direto com pacientes... não acho que dentes extraídos façam parte deste grupo, ou seja, não acho que deveria ser concebido como pesquisa envolvendo seres humanos..."

P17: "São as pesquisas com seres humanos direta ou indiretamente... é claro, que para avaliação, com pesos diferentes, ou seja, se vou utilizar seres humanos diretamente, in vivo o critério de avaliação deverá ser mais rigoroso quando se uso dados de pacientes, indiretamente..."

P18: "Toda pesquisa que lida com seres humanos em qualquer área e qualquer material que veio do ser humano... até DNA... e acho que tem o mesmo peso. "

P19: "Todas aquelas pesquisas que envolvam seres humanos direta ou indiretamente, como dados, informações, etc. "

P20: "Um simples questionário já está envolvendo seres humanos... os dados, as informações de pessoas, tudo isso já é pesquisa com seres humanos... biópsia nem se fala..."

P21: "Apenas quando há participação de seres humanos, pessoalmente."

P22: "Tudo que envolve procedimentos novos, novos fármacos e parte relacionada ao comportamento humano... dados, material humano..."

P23: "Qualquer dado que envolva seres humanos."

P24: "Qualquer pesquisa que envolva o ser humano, não necessariamente direto com ser humano."

P25: "Toda pesquisa que envolva direta ou indiretamente os indivíduos... os órgãos, células, entrevistas, tudo isso é pesquisa com seres humanos."

P26: "É desde uma pergunta até uma intervenção invasiva ..."

P27: "Pesquisa que trabalha com boca, questionário não são pesquisas envolvendo seres humanos... é só quando envolve o ser humano diretamente."

P28:"São pesquisas que envolvam o ser humano diretamente... não acho que dente é pesquisa com seres humanos."

QUESTÃO 7: - DE QUE FORMA VOCÊ ENVOLVEU OS PACIENTES A PARTICIPAREM DAS SUASPESQUISAS? (convidado/convocado...)

P1: "Pediria autorização, convidaria..."

P2: "Explicava o tratamento, apresentava o Termo de Consentimento, informava a respeito de tratamento alternativo." 
P3: "Faria através de perguntas e respostas... São pacientes, assim, informava sobre a pesquisa, fazia a entrevista e apresentava o Termo de Consentimento."

P4: "Falando com os pacientes... primeiro o consentimento verbal, depois o formal, que é esse Termo que você me apresentou... faria o convite."

P5: "No atendimento, Campanha da Vacinação eu examinava as crianças, preenchia os dados anamnéticos e o exame clínico... os convidaria."

P6: "Primeiro fiz contato em 1ํ lugar com a Secretaria de Saúde daquele município para obter o consentimento e os dados das escolas... assim, entreguei todo o material para Diretoria e professores das escolas e o questionário junto com 0 Termo de Consentimento foram enviados aos pais através dos alunos... quem os enviou de volta consentiu a participação."

P7: "Como já existia CEP organizado aqui, o paciente era esclarecido sobre a pesquisa."

P8: n. r.

P9: n. r.

P10: "Explicava sobre a pesquisa e deixava o questionário no consultório do CD $\mathrm{p} /$ responder... com pacientes, explicava se permitia examinar a boca (exame bucal) para participar da pesquisa."

P11: "Caso eu fizesse falaria da importância do trabalho para o futuro da ciência... melhora de qualidade de vida..."

P12: "Informo sobre a pesquisa (objetivos), informo também que aquele caso é interessante para a pesquisa e, caso permitam, entrego o termo de consentimento."

P13: "Conscientizando o paciente que o trabalho (pesquisa) poderia ajudar no futuro..."

P14: "Bom, como nunca fiz, penso que faria assim: Primeiro iria no local onde os pacientes ficam, por exemplo os da prótese total. Pegaria a relação de todos os pacientes (nomes), reuniria todos eles em uma sala e mostraria o problema, ou seja, a proposta da pesquisa, explicaria os benefícios e os convidaria para participar de minha pesquisa... entregaria um ficha para preenchimento dos dados e o termo de consentimento... explicaria tudo na linguagem deles, simples, pois aqui acontece muito do profissional falar a linguagem técnica para o paciente, já ví muitas vezes... o paciente aceita pois é o "doutor" que está falando..."

P15: "Bom, não precisei informa-los, já havia um trabalho em andamento... eles já estavam motivados para ajudar... era uma coleta de saliva e umas perguntas... "

P16: "Eu chegava, me apresentava e perguntava se eles poderiam participar... explicava o projeto. "

P17: "Bom, eram pacientes do ... (nome da instituição). Selecionamos o grupo de pacientes e aí explicávamos a pesquisa... falava sobre os riscos e colocava-se à disposição... muitos recusaram-se a participar devido ao risco e/ou exposição... "

P18: "Selecionei os pacientes pelo quadro clínico... explicava a cada um sobre a pesquisa e pedia o consentimento... "

P19: "Acho que mostraria o objetivo do trabalho, o benefício... iria motivá-los... e deixaria claro que ele não seria prejudicado se não desejasse participar. " 
P20: "Bom, minha pesquisa será com CDs. Enviarei pelo correio ou entregarei na sala de cursos de especializações os formulários e carta de apresentação da pesquisa... nesta carta colocarei a proposta da pesquisa e explicarei sobre o sigilo das informações das pessoas ..."

P21: "Eram pacientes do ambulatório... naquela época não existia comitê... "

P22: "Conversei com eles, apresentei a pesquisa, o histórico... falei da importância de obter aqueles dados, dos riscos e benefícios... e daí solicitei a participação... a participação voluntária! “

P23: "Convidando-o ... conscientizando para fins de pesquisa... afirmava que teria liberdade de aceitar ou não... "

P24: "Os pacientes eram encaminhados para avaliação... explicava a pesquisa, o objetivo, sobre 0 questionário e apresentava 0 termo de consentimento..."QUESTIONEI SE OS PACIENTES TINHAM NOÇÃO SOBRE A DIFERENÇA QUE AQUELES PROCEDIMENTOS ERAM DE UMA PESQUISA OU CONFUNDIAM COM PROCEDIMENTOS DO PRÓPRIO TRATAMENTO. RESPOSTA: "Não, mesmo explicando eu tenho certeza que eles imaginavam que aquelas perguntas faziam parte da rotina do tratamento."

P25: "São pacientes especiais... chegamos neles através da autorização da instituição onde eles eram acompanhados. Na pesquisa com alunos, fomos nas classes, pedimos ao professor um tempo para explicar a pesquisa e chamamos voluntários."

P26: "Mostrando a importância da participação... que os resultados seriam importantes para eles."

P27: "Mostrando que sua participação poderia trazer resultados positivos... "

P28: “... Você precisa de (....) ... Quer fazer?... O benefício era a dentadura... não essa "coisa" de comitê de ética. "

QUESTÃO 8: COMO FOI OU COMO VOCÊ PRETENDE APLICACAR OS QUESTIONÁRIOS E/OU ENTREVISTAS? DE QUE FORMA ABORDOU OU PRETENDE ABORDAROS SUJEITOSDAPESQUISA:

P1: a mesma resposta anterior.

P2: "Explicação oral, a finalidade da pesquisa e apresentação do Termo de Consentimento."

P3: a mesma resposta anterior.

P4: a mesma resposta anterior.

P5: a mesma resposta anterior.

P6: Questionário: "Envio dos questionários para os pais das crianças através das escolas".

Entrevista: "Permissão na Secretaria de Saúde, fui aos postos de saúde e convidei as atendentes para participarem da minha pesquisa, solicitando-as que respondessem meu questionário e aí, informando sobre o objetivo de minha pesquisa." 
P7: Entrevista: "Informando previamente ao paciente sobre a proposta da pesquisa."

P8: n. r.

P9: n. r.

P10: Questionário: "Fui nos consultórios de CD, explicava sobre a pesquisa e deixava o questionário $\mathrm{p} / \mathrm{responderem."}$

Entrevista: "Após o atendimento de urgência (pacientes), me identificava e explicava sobre a pesquisa, pedia permissão p/examinar a boca para realizar a pesquisa."

P11: n. r.

P12: Questionário: "Informo sobre a pesquisa e entregava o questionário ao paciente para preenchimento."

Entrevista: "Informo sobre a pesquisa e inicio a entrevista."

P13: Questionário: "Me apresentei, informei sobre o objetivo da pesquisa e o convidei para colaborar..."

P14: n. r.

P15: Entrevista: "As pessoas já haviam aceitado antes no momento que entrei para a entrevista, sendo assim já sabiam da pesquisa e já deram seus consentimentos."

P16: Entrevista: "Perguntava se queria participar da pesquisa."

P17: Entrevista: "A entrevista que fiz foi a própria anamnese."

P18: Questionário: "Esperava o paciente, pedia o consentimento e pedia para preencher o questionário."

P19: Questionário: "Acho que o questionário deve ter questões práticas, tipo "sim" e "não" para não cansar as pessoas..."

P20: n. r.

P21: n. r.

P22: Entrevista: "As entrevistas foram feitas com profissionais... os selecionamos pela aproximação local, daí explicávamos a proposta da pesquisa."

P23: Questionário: "Expliquei a pesquisa e pedi para o paciente preencher as questões de acordo com a sua compreensão..." direcionadas a pesquisa."

Entrevista: "Informava a proposta da pesquisa e fazia perguntas

P24: "As perguntas eram diretas... tivemos o cuidado de adequar a linguagem mais comum p/que eles entendessem... eles achavam que fazia parte de uma avaliação do tratamento."

P25: Questionário: "Entregava os questionários, pedia o preenchimento, esclarecia que era voluntário..."

P26: Questionário: "Foram dentistas que estavam fazendo curso, explicava em sala de aula o questionário e pedia para responderem, solicitando a autorização do professor." 
P27: Questionário: "Informava que era uma pesquisa, solicitava a contribuição deles "

P28: Questionário: "Informávamos que aquele questionário iria ser usado para pesquisa... alguns, "trocamos" pela (....)."

\section{QUESTÃO 9.2: OQUE VOCÊ ACHA DE TRABALHAR COM DETENTOS?}

P1: "Não trabalharia. Seria uma situação desconfortável, sentiria medo..."

P2: "Não iria na Casa de Detenção, por segurança... mas caso o detento estivesse na instituição de saúde onde trabalho precisando de tratamento o atenderia, e talvez, se fosse o caso, faria pesquisa."

P3: "Não entraria em contato pessoal pois teria medo, talvez trabalhasse com dados deles: prontuários, etc."

P4: "Nenhum problema. Os abordaria diferente, seguindo as normas da instituição (segurança)."

P5: "Neste caso existe um problema ético: eles fazem parte de um Grupo Especial para fazer pesquisa, ou seja, talvez estariam sendo obrigados a participarem da pesquisa."

P6: "Não teria coragem, por medo. Para mim não seria um grupo ideal."

P7: "Trabalharia normalmente, obtendo todos os consentimentos necessários (instituição)."

P8: "Desde que oferecessem condições de segurança".

P9: "Teria receio... por medo talvez, porém acho que é um grupo mais fácil de controle para o acompanhamento da pesquisa... acho que eles não estão presos inocentemente, portanto fizeram algo de errado e assim, não vejo problema algum eles darem suas contribuições para o sucesso da ciência participando de pesquisas, assim como devem trabalhar, produzir sua própria alimentação."

P10: "Não haveria nenhum problema, para mim é normal como qualquer paciente."

P11: "Depende, só faria se fosse realmente esse o meu público alvo."

P12: "Se eu tivesse tempo p/ir ao local (penitenciária) não haveria problema algum, mas para eles saírem de lá p/vir aqui, aí não acharia legal... por questão de segurança... correr riscos. Acho que p/os meus pós-graduandos não seria legal, principalmente para as mulheres, teria receio. Se eu tivesse a opção de não trabalhar com eles, não trabalharia."

P13: "Não teria problemas, mas faria com a permissão dos próprios detentos."

P14: "O Estado que estaria oferecendo? Do jeito que você falou (A Penitenciária oferecendo detentos para participarem de pesquisa) até parece que eles não são pessoas, parece que está oferecendo um número $X$ de gados para pesquisar. Não concordo com isso. Não importa quem for, presos, doentes mentais, o que for... são pessoas e elas têm o direito."

P15: "Sem problemas... tudo bem! Mesmo sendo institucionalizados..." 
P16: "Se possível não trabalharia... por segurança não trabalharia... e também não trabalharia sem o consentimento dos detentos, sem a vontade deles."

P17: "Só trabalharia desde que houvesse o consentimento individual dos detentos."

P18: "Não trabalharia em razão de serem detentos... por segurança."

P19: "Eles podem se sentirem coagidos... se fosse de livre e espontânea vontade, trabalharia."

P20: "Por um lado é bom, por outro é péssimo... você poderia estar fazendo um bem para aqueles pacientes e por outro lado, eu teria medo por questão de segurança pessoal."

P21: "Sem problemas ... Trabalharia mesmo apenas com o consentimento da instituição..."

P22: "Não trabalharia... é uma população confinada... estariam servindo como cobaias ... seriam obrigados a participar... eles devem ser tratados como todos os seres humanos... e também não concordaria que eles tivessem diminuição de pena por estarem participando de pesquisa, não acho justo!"

P23: "Normal... trabalharia... o problema é que é uma amostra viciada, são grupos direcionados... tirando isso, sem problemas..."

P24: "Trabalharia na boa... buscaria o consentimento da pessoa... já trabalhei com detentos."

P25: "Do ponto de vista ético é a mesma coisa que "grupos especiais", são também sujeitos de pesquisa especiais, eles não têm autonomia plena."

P26: "Dependeria da organização e segurança do presídio... tentaria obter a autorização de todos."

P27: "Não há problema desde que haja segurança... também procuraria obter a autorização de todos."

P28: "Se for objeto da minha pesquisa, trabalharia... quanto ao consentimento, buscaria individualmente, até por quê, caso não queira participar , poderiam atrapalhar o bom andamento da pesquisa..."

\section{QUESTÃO 10: QUE SITUAÇÕES DE "RISCOS"PODE EXISTIR QUANDO APLICA-SE} QUESTIONÁRIOS E/OU ENTREVISTAS?

P1: "Pode existir um desconforto relacionado aos valores, a moral do paciente, principalmente quando as perguntas são sobre a sexualidade, ou DSTs."

P2: "Depende do assunto e da pessoa que se está entrevistando, como também, do jeito que o assunto será abordado. Há então a possibilidade de existir riscos psicológicos e/ou morais."

P3: "Não há riscos."

P4: "Não vejo possibilidade de riscos, desde que o questionário e/ou a entrevista estejam bem elaborados... boa formulação de perguntas... depende da abordagem do pesquisador."

P5: "Acredito que possua a possibilidade de desconforto moral e emocional." 
P6: "Acredito que tenha riscos. Desconforto... talvez pela obrigação de Ter que responder, pode trazer lembranças que não gostaria... lembrança ruim... porém são poucas essas que causam riscos... A entrevista é pior que o questionário pois ela intimida as pessoas."

P7: "Talvez haveria riscos emocionais."

P8: "Possibilidade de desconforto moral, perguntas constrangedoras".

P9: "Não consigo ver riscos. Na entrevista há um desconforto com perguntas constrangedoras que podem afetar o sujeito, por isso, ela deve trazer algum benefício. Não vejo este um fator de impedimento em realizar a pesquisa."

P10: "Situações de desconforto moral, a maneira como conduzo a pesquisa com o paciente. Também se eu não tiver cuidado com o sigilo dos dados coletados."

P11: "Não acredito que possua riscos... há riscos para o pesquisador como por exemplo, responderem algo errado, prejudicando o resultado da pesquisa."

P12: "O paciente pode se sentir envergonhado, constrangido, humilhado, dependendo das questões. É um desconforto emocional e psicológico. E um risco para a pesquisa é os dados não serem verídicos, ou seja, os pacientes não falarem a verdade."

P13: "Apenas se a pessoa não estiver disposta em responder as perguntas."

P14: "Claro que tem riscos... tipo desconforto... social, sentimento de discriminação ... pose-se invadir a privacidade da pessoa e talvez esta pessoa não esteja preparada."

P15: "Acredito que não tenha riscos... há apenas para o pesquisador... as respostas podem não serem verídicas."

P16: "Não tem riscos... desde que a participação seja espontânea."

P17: "Há riscos... má interpretação de algumas questões... as pessoas podem se sentirem ofendidas... depende do grupo que está trabalhando."

P18: "Tem riscos como de exposição da sua pessoa... não sei se o outro é ético ou não... está exposto a constrangimento... causar desconforto..."

P19: "Respostas não verídicas devido ao medo de ser discriminado ... quando o paciente está com dor de dente e perguntamos se tem dor ou sensibilidade, geralmente ele fala que tem dor com medo do dentista não leva a sério seu problema... essas questões..."

P20: "Existe algum tipo de desconforto relacionado a quebra do sigilo... o paciente fica com medo... pode-se fazer perguntas que trás a tona problemas emocionais do paciente... um dia, na pesquisa do IBGE, a entrevistadora perguntou para uma pessoa que era portadora de esquizofrenia se era casada e por causa disso a pessoa teve uma crise pois nunca casou... não sabemos a priori o que a pessoa tem de problemas."

P21: "Para mim há risco para o pesquisador... as podem mentir..."

P22: "Acredito que exista um risco potencial de identificar a pessoa que está participando da pesquisa... respostas incoerentes... também acho que pode causar uma ansiedade, um desconforto na pessoa... talvez por receio..." 
P23: "Há riscos... omitir fatos... inibições, vergonha, má interpretação... há também uma exposição pessoal."

P24: "Há riscos... forçar um determinado resultado... não ser suficientemente claro nas interpretações, resultar em dados incorretos... dependendo da questão pode ter um desconforto."

P25: "Acho que deve Ter um risco mínimo... talvez um desconforto..."

P26: "Não há. Algumas pessoas podem sentir-se constrangidas..."

P27: "Não há riscos."

P28: "Dependendo do tipo de pergunta, podem ficar constrangidos."

QUESTÃO 11.1: VOCÊ CONHECE A RESOLUÇÃO № 196/96 DO CONSELHO NACIONAL DE SAÚDE? A QUE SE REFERE?

P1: "Pelo número não reconheço."

P2: "Sim, é sobre ética em pesquisa."

P3: "Não. Já ouvi falar..."

P4: "Não. “

P5: "Sim, sobre ética em pesquisa."

P6: "Sim, normas, diretrizes para elaboração de pesquisa envolvendo seres humanos."

P7: "Não. "

P8: "Não. “

P9: "Sim. "

P10: "..Um pouco... quer dizer: todas as pesquisas só devem ser iniciadas após aprovação do comitê de ética... acho que é isso."

P11: "Não."

P12: "Não."

P13: "Não, pelo número não identifico."

P14: "Não. Talvez alguém já comentou comigo mas nunca a vi."

P15: "Sim, sobre ética em pesquisa."

P16: "Não. Já vi mas não lembro de ter lido."

P17: "Não tenho certeza... é sobre ética em pesquisa com seres humanos?"

P18: "Não."(Reconheceu depois da orientação do pesquisador.)

P19: "Não. Algo sobre ética."

P20: "Não lembro."

P21: "Não." 
P22: "Sim, já ouvi falar... é sobre ética em pesquisa com seres humanos e animais."

P23: "Não."

P24: "Sim, tive que conhecer para fazer meu projeto. É sobre ética em Pesquisa com seres humanos e animais."

P25: "Sim. Normativa de condutas com relação aos aspectos éticos em pesquisa."

P26: "Sim. Ética em pesquisa."

P27: "... já ouvi falar..."

P28: "Não."

QUESTÃO 11.2: COMO VOCÊ VÊ ESTA RESOLUÇÃO EM RELAÇÃO AS SUAS PESQUISAS? (nesta questão tentar identificar o papel da Resolução para os pesquisadores: colaborador, parceiro, "mais uma burocracia", etc)

P1: "Deve ser aplicável... é boa, correta... deveria vir antes."

P2: "Acho importante, colabora com nosso trabalho."

P3: "Deve ser importante para orientar os CEPs."

P4: "Tem sentido legal, normativo... não pode ser interpretado da mesma maneira, depende de cada contexto... sua avaliação depende de vários fatores... Esta Resolução deveria ser adaptada àrealidade. "

P5: "Ela contribui... orienta os procedimentos que devemos tomar."

P6: "Para mim o papel da resolução é de orientador. Muitas vezes você está envolvido na pesquisa e não percebe algo que seja importante para a reflexão ética.

P7: "É necessária. Muita coisa estava desorganizada. “

P8: "Não conheço, porém você me dizendo o que ela é, acho importante... o que é certo para mim, pode não ser certo para você.

P9: "Acredito que esta Resolução colaborou para a diminuição de pesquisas clínicas... ninguém quer mais fazer pesquisa clínica. Acho também que trouxe uma necessidade de discussão ética. Há um fato preocupante: a restrição. Para outras pessoas, não para mim pois não utilizo seres humanos em minhas pesquisas, mais é visto como mais uma burocracia. "

P10: "É uma referência para iniciar sua pesquisa. “

P11: "Acho que é necessária... também é lógico que é mais uma burocracia p/nós pesquisadores... mas é preciso principalmente para aquelas pesquisas que são mais agressivas. "

P12: "Acho que me ajudou... na preparação do meu projeto de pesquisa, porém não me sinto capacitado para avalia-la... é uma lei, um regulamento e como todas as leis deve ter algo há questionar..."

P13: "Ela é regulamentadora... muitas vezes ela atrapalha no sentido de limitar a pesquisa." 
P14: "Tudo que fazemos tem que ter uma ética... moramos numa sociedade e vivemos de acordo com determinadas regras, normas... é normal. Existe norma para tudo. Acho importante termos esta resolução... se não fosse assim não existiria nenhum controle. "

P15: "É válida... é necessária... só que as avaliações dos CEPs... "

P16: "Deve ter um motivo, deve ter uma razão dela ter sido criada, porém a forma que está sendo aplicada pelos comitês deveria ser melhor. "

P17: "Para o momento é excelente... antes tarde do que nunca... acho que ela é colaboradora com nossas pesquisas. "

P18: "É burocrática... dificulta as pesquisas... é fundamental a sua existência mas deve ser melhor trabalhada. “

P19: "Acho que vai me dá mais trabalho mas é necessária... "

P20: "Acho que falta clareza... ela é bem intencionada... é mais importante que a criação de comitê... "

P21: "Veio para atrapalhar... não tenho considerações a respeito. “

P22: "É um orientador... já li, acho que serve como um guia de orientações... muitas vezes me ajudou até nos meus atendimentos com pacientes... "

P23: "Um mal necessário! Poderia simplificar um pouco mais as orientações... "

P24: "É um norteador para pesquisas. "

P25: "Instrumento para nortear as pesquisas com relação aos aspectos éticos. "

P26: "É importante. É orientadora. Ela unifica, tem uma direção para as pessoas não estarem fazendo pesquisa de qualquer modo. "

P27: "Dependendo do tipo de pesquisa, veio para contribuir... por outro lado, veio para complicar as pesquisas mais simples. "

P28: "Na verdade acaba limitando as pesquisas, você termina perdendo tempo para conhecer esses documentos... acho que dificulta para o pesquisador... "

\section{QUESTÃO 11.3: COMO VOCÊ VÊ OTRABALHO DOS CEPs?}

P1: "Burocrático... não é prático..."

P2: "Ótimo."

P3: "Há uma dificuldade de avaliação... é necessário avaliar melhor a relevância da pesquisa... às vezes se apega em detalhes, como por exemplo mudar palavras que são semelhantes e aí todo o trabalho atrasa pela demora de resposta do CEP. Isto é o que escuto de outros colegas... eu não tive problemas. O trabalho é importante." 
P4: "No (....) o CEP trabalha para evitar a "pirataria"e aqui eu não vejo isto. Há muita "pirataria"de trabalhos. No Brasil, acredito que o trabalho dos CEPs limita o desenvolvimento do pesquisador, é feio... é abrupto... o pesquisador não tem o direito de indagar os pareceres... muitas vezes o avaliador (parecerista) não é competente da área ao qual esta avaliando a pesquisa. Há uma falta de debate científico, discussão mesmo, entre as duas partes... quero questionar as indagações do avaliador e não me dão este espaço. Sem contar com os fatores políticos que nem quero comentar... (Benefício de outros em razão de posições, cargos...)."

P5: "É bom pois temos uma orientação ética, me obriga a rever meus parâmetros éticos... falta flexibilidade com avaliação de algumas pesquisas com seres humanos."

P6: "Eu admiro. A maioria das pessoas não gostam pois demoram para entregar a resposta (do parecer). Acho importante, alguém tem que fazer isso. Poderia se mais ágil por isso acho que as pessoas deveriam ser remuneradas para este trabalho... haveria mais tempo para se dedicar ao trabalho de avaliação ética. "

P7: "Acho que há uma falta de consenso... falta critérios de avaliação entre os CEPs. Há demora nas respostas (parecer), falta de uma unidade, uma direção única. A existência de um CEPsem dúvida é positiva. "

P8: "No começo demorava mais (as respostas do parecer). Acho necessário este trabalho. "

P9: "É um trabalho sério. A dinâmica de trabalho é lenta, avaliação dos projetos é lenta... deveria orientar melhor os pesquisadores que direcionam as pesquisas na Faculdade, ou seja, deveria chegar mais próximo dos professores que coordenam e orientam linha de pesquisa. "

P10: "Na minha experiência com o CEPfoi positiva, não tive problemas, foi rápido... para mim tudo é desconhecido pois na Faculdade que estudei não lembro de ter CEP... foi interessante saber, conhecer... tenho amigos que têm reclamado muito devido a demora de resposta da avaliação. "

P11: "Para mim não significa nada... a existência dele aqui na Faculdade é importante. "

P12: "Acho o trabalho super importante... tem que ter no começo até desenvolver uma cultura ética em pesquisa na Faculdade... acredito que futuramente não necessitaremos do Comitê, cada pesquisador será responsável pela avaliação ética de seu trabalho, ou seja, poderá contratar um consultor ético para ser feita avaliação... não será mais responsabilidade da instituição e sim do pesquisador ... também que este ponto está longe de chegar... é preciso desenvolver mais nas pessoas esse senso ético... enquanto comitê creio que há vários problemas de ordem administrativa e de avaliações, porém acho necessário sua existência. "

P13: "Acho que eles são tendenciosos... não há critério de análise, acho que o critério é nome do orientador ... entraves políticos... resumindo, acho o trabalho negativo. "

P14: "Acho legal... acho também que ele precisa ter muito mais presença na Faculdade, parece que só existe no papel... deveria ter uma pessoa no local do Comitê para orientar os pesquisadores e informar isto para todo mundo. Acho importante sua existência se não, não há controle. " 
P15: "Há exageros nas avaliações dos projetos... se apegam a detalhes... demoram na entrega dos pareceres, porém acho necessário tê-lo... Precisamos de um órgão regulador. "

P16: "Está funcionando de forma boa, rápida... Há alguns problemas: evito de trabalhar com dentes devido a demora do processo de avaliação do comitê... Acho que eu não precisaria provar para o comitê que vale a pena fazer a pesquisa com dentes. "

P17: "Acho que eles pecam pelo excesso... são questões pessoais, individuais... eles impedem pesquisas que são epidemiológicas... tem que ser revisto as pessoas que fazem parte do CEP... se são realmente qualificadas. "

P18: "Discordo das avaliações... o avaliador deve ser profissional específico de ética em pesquisa... Acho necessário ter um comitê centralizado... o cirurgiãodentista não tem condições de avaliar ética em pesquisa. "

P19: "Acho importante... alguns demoram na avaliação... em animais poucos lugares têm comitês. "

P20: "Primeiro acho de suma importância o comitê... sei que é bem rigoroso... e precisa ser! Falta uma certa homogeneidade dos avaliadores... falta constância... é necessário uma avaliação homogênea. "

P21: "É útil... “

P22: "É importante... Sei que são bastante rigorosos... exigem muita coisa... Nos CEP de animais eles são menos rigorosos, eles se preocupam apenas com o tratamento que daremos ao animal, não importa se a pesquisa irá trazer algum benefício ou não... eles não pedem o projeto de pesquisa para ver material e método apenas pedem para preencher uma ficha para saber como trataremos o animal... 0 CEP daqui é mais completo... "

P23: "É muito burocrático... demoram nas avaliações... rigoroso... Acho importante sua presença, mas devia existir mais para evitar abusos do que de controlar."

P24: "É um fator complicador... o problema não é a existência do CEP, acho importante, a questão é a falta de acesso do pesquisador ao CEP... ou seja, os pesquisadores não conseguem defender sua pesquisa, elas são aceitas ou não. "

P25: "Ainda está lento... anda um pouco rigoroso, por outro lado, é extremamente necessário. A avaliação é boa... a conduta é boa... "

P26: "Ele ajuda o pesquisador pois é também responsável pela pesquisa. Acho que se deve ter mais atenção nas relatorias... "

P27: "Não tem o por quê de ficar voltando para lá e para cá. A avaliação deveria ser mais "branda"quando envolve apenas questionário... Não deveria ser necessário passar no CEPquando não envolve seres humanos diretamente. "

P28: "O comitê tem o seu valor, pois muitas vezes, em nome da ciência fizeram muita coisa errada, porém você é que deve assumir as conseqüências... não precisava existir se cada um assumisse o seu papel de responsabilidade... na odonto eles só enxergam a boca e não o ser humano como um todo... " 
QUESTÃO 13: OQUEÉÉTICAEM PESQUISA?

Observação: as respostas desta questão são apresentadas na íntegra no capítulo 5.2.8 dos resultados e discussão deste trabalho. 


\begin{abstract}
ANEXO 3
TERMO DE CONSENTIMENTO LIVRE E ESCLARECIDO
\end{abstract}

$\mathrm{Eu}$, aceito participar da pesquisa: "A compreensão dos pesquisadores da Odontologia sobre ética em pesquisa envolvendo seres humanos". Fui devidamente informado e esclarecido sobre os objetivos da pesquisa sabendo que minha participação não ocasionará nenhum risco ou desconforto a minha pessoa. A minha participação é livre e voluntária. E baseia-se em responder a perguntas sobre o assunto do tema apresentado através do roteiro de questões da pesquisadora.

Tenho clara convicção que posso desistir da minha participação na pesquisa a qualquer momento.

A pesquisadora compromete-se em não divulgar nenhum dado que identifique a minha pessoa.

Assim, autorizo a publicação dos dados coletados na entrevista.

São Paulo, de de 2002.

Assinatura do Participante

Pesquisadora: Luciana Maria Cavalcante Melo

Fone contato: 9101-8088

Orientador: Prof. Dr. Dalton Luiz de Paula Ramos

Instituição responsável: Faculdade de Odontologia da USP 
ANEXO 4 


\section{REFERÊNCIAS *}

Alves EGR, Ramos DLP. Profissionais de saúde: vivendo e convivendo com HIV/AIDS. São Paulo: Ed. Santos; 2002.

Alves EGR. O cirurgião-dentista e outros profissionais de saúde portadores de HIV/AIDS : considerações bioéticas e psicológicas. [dissertação] São Paulo (SP): Faculdade de Odontologia da USP; 2001.

Alves EGR. Relacionamento cirurgião-dentista e paciente. Odont e Socied 2000; 2: 6-7.

Amaral LA. Resgatando o passado: deficiência como figura e vida como fundo. [dissertação] São Paulo (SP):Faculdade de Psicologia Pontifícia Universidade Católica de São Paulo; 1987.

Anjos MF. Bioética nas desigualdades sociais. In: Garrafa V, Costa SIFC, organizadores. A bioética no século XXI Brasília: Ed. Univ. Brasília; 2000. p.49-65.

Araújo LZS. Verificação da utilização de seres humanos e animais em pesquisas científicas, frente aos fundamentos e preceitos da bioética. [dissertação] Maceió (Al), Escola de Ciências Médicas de Alagoas da UFAL e UFF ;1999.

\footnotetext{
* De acordo com Estílo Vancouver. Abreviatura de periódicos segundo Bases de Dados MEDLINE.
} 
Barboza HH. Princípios da bioética e do biodireito. Bioética 2000; 8: 209-16.

Bardin, L. Análise de conteúdo. Lisboa: Edições 70, 1979.

Barroco MLS. Ética e Serviço Social: fundamentos ontológicos. São Paulo: Cortez, 2001.

BRASIL. Ministério da Saúde / Fundação Nacional de Saúde. Conselho Nacional de Saúde (CNS). Diretrizes e Normas Regulamentadoras de Pesquisas em Seres Humanos. Informe Epidemiológico do SUS. Supl.3(2), 1996.

Buey FF. Sobre tecnociencia y bioética: los árboles del paraíso - parte II. Bioética 2000; 8: 187-204.

Caggiano MHS. Direitos humanos e aprendizado cooperativo In: Liberal MMC. (Org.) Ética e cidadania. São Paulo: Mackenzie; 2002. p. 95-113

Campbell AV. Uma visão internacional da bioética. In: Garrafa V, Costa SIFC, organizadores. A bioética no século XXI. Brasília: Ed. Univ. Brasília; 2000. p.25-35.

Clotet J. Bioética como ética aplicada e genética. In: Garrafa V, Costa SIFC, organizadores. A bioética no século XXI. Brasília: Ed. Univ. Brasília; 2000. p.109-28.

Cohen C, Marcolino JAM. Relação Médico - Paciente: Autonomia \& Paternalismo. In: Segre M, Cohen C. Bioética. São Paulo: Edusp; 1995. p.51-62.

Cohen C, Segre M. Definição de valores, moral, eticidade e ética. In: Segre M, Cohen C. Bioética. São Paulo: Edusp; 1995. p.13-22.

Demo P. Avaliação qualitativa. 5 $5^{\underline{a}}$ ed. Campinas: Autores Associados; 1995 (Coleção polêmicas do nosso tempo). 
Durand G. A bioética: natureza, princípios, objetivos. (Trad. de Porphírio Figueira de Aguiar Netto). São Paulo: Paulus; 1995.

Faculdade de Odontologia da Universidade de São Paulo. Regimento Interno. São Paulo; 1993.

Ferreira $A B H$. Minidicionário da língua portuguesa. $3^{\text {a }}$ ed. Rio de Janeiro: Nova Fronteira; 1993.

Ferreira $\mathrm{ABH}$. Novo dicionário básico da língua portuguesa Folha/Aurélio. São Paulo: Folha de São Paulo/ Rio de Janeiro: Nova Fronteira, 1995.

Fortes PAC. Ética e Saúde: questões éticas, deontológicas e legais. São Paulo: EPU; 1998.

Galitesi CRL. As mil e uma faces do dente: odontologia, antroposofia e evolução. São Paulo: Antroposófica: Weleda do Brasil; 2000.

Garrafa V, Costa SIFC, organizadores. A bioética no século XXI. Brasília: Ed. Univ. Brasília; 2000.

Gauderer EC. Os direitos do paciente. São Paulo: Círculo do Livro, 1991.

Gelbier S, Wright D, Bishop, M. Ethics and Dentistry: 1. the meaning of ethics. Dent Update. 2001(a); 28: 468-73.

Gelbier S, Wright D, Bishop, M. Ethics and Dentistry: 2. ethics and risk management. Dent Update 2001(b); 28: 524-27.

Gil AC. Métodos e técnicas de pesquisa social. $2^{\mathrm{a}}$ ed. São Paulo: Atlas; 1989.

Golffman E. Estigma: notas sobre a manipulação da identidade deteriorada. $4^{\mathrm{a}}$ ed. Rio de Janeiro: Zahar; 1998. 
Gomes R. A análise de dados em pesquisa qualitativa. In: Minayo MCS (Org.); Deslandes SF, Cruz ON, Gomes R. Pesquisa social: teoria método e criatividade. Petrópolis, RJ: Vozes; 1994. p. 67-80

Gouvêa RQ. Ética e cidadania - a busca humana por valores solidários - In: Liberal, M.M.C. (Org.) Ética e cidadania. São Paulo : Ed. Mackenzie; 2002. p. 09-29.

Graciano MIG, Neves Filho A, Lehfeld NAS. Critérios de avaliação para classificação sócio-econômica: elementos de atualização. Serviço Social \& Sociedade 1999; 8: 109-28.

Heller A. Valor e História - O Cotidiano e a História. Rio de Janeiro: Paz e Terra, 1991; p. 1-15.

Hossne WS. Bioética no Brasil e a Resolução 196 (editorial). Cad Et Pesq CONEP $2001(\mathrm{~b}) ; 4: 3-4$

Hossne WS. Ética? Isso é coisa de filósofo (editorial). Cad Et Pesq. CONEP 2001(a); 4: 3.

Josaphat FC. Moral, amor e humor. Rio de Janeiro: Record: Nova Era; 1997.

Lauand LJ. (Org.) Ética: questões fundamentais. Coleção Raízes. São Paulo: EDIX; 1997.

Lima CP. Nos limites do mundo - o futuro da ciência e da pesquisa. Femina 2000; 28: 569-71.

Lolas F. Bioética - o que é, como se faz. (Trad. de Milton Camargo Mota). São Paulo: Loyola; 2001.

Marcos B. Ética e profissionais da saúde. São Paulo: Ed. Santos; 1999.

Maruyama NT. Implicações éticas da AIDS na prática odontológica. [dissertação] São Paulo (SP): Faculdade de Odontologia da USP;1999. 
Minayo MCS. Ciência, técnica e arte: o desafio da pesquisa social. In: Minayo, MCS (Org.); Deslandes SF, Cruz ON, Gomes R. Pesquisa social: teoria método e criatividade. Petrópolis, RJ: Vozes; 1994. p. 09-29

Nogueira-Martins MCF. Humanização das Relações Assistenciais: A formação do profissional de saúde. São Paulo: Casa do Psicólogo; 2001.

Oselka GH. Helsinque: mudança inaceitável. Cad. Et Pesq. CONEP 2000; 3: 20-1.

Passos E. Ética na Pesquisa. Rev Baiana de Enf 1994; 7: 105-14.

Pessini L, Barchifontaine CP. Bioética: do principialismo à busca de uma perspectiva latino-americana. IN: Costa SIF, Garrafa V, Oselka G (Org.) Iniciação àBioética. Brasília: CFM; 1998. p.81-98.

Pessini L, Barchifontaine CP. Problemas atuais de bioética. $3^{\mathrm{a}}$ ed. São Paulo: Loyola; 1996.

Ramos DLP. Ética odontológica: o código e ética odontológica (Resolução CFO- 179/91) comentado. São Paulo: Santos; 1994.

Salomão LC, Silva PF. Bioética: valores e atitudes do século XXI. In: Liberal MMC, organizadora. Ética e cidadania. São Paulo: Ed Mackenzie; 2002. p.81-93.

Samico AHR, Menezes JDV, Silva M. Aspectos éticos e legais do exercício da Odontologia. $2^{\mathrm{a}}$ ed. Rio de Janeiro: CFO;1994.

Sarmento HBM. Bioética, direitos sociais e serviço social. [tese] São Paulo (SP): Faculdade de Serviço Social da PUC-SP; 2000

Sarmento HBM. Instrumentos e técnicas em serviço social. [dissertação] São Paulo (SP): Faculdade de Serviço Social da PUC-SP. 1997

Sawaia BB. A ética nas ciências humanas. Cad Et Pesq 2000; 3: 14-17. 
Sawaia BB. O sofrimento ético-político como categoria de análise da dialética exclusão/inclusão. IN: Sawaia, B. B. (Org.) As artimanhas da exclusão: análise psicossocial e ética da desigualdade social. Rio de Janeiro: Vozes (Coleção Psicologia Social); 1999. p. 97-118.

Schramm FR. Da bioética privada à bioética pública. In: Fleury $S$, organizadora. Saúde e democracia: a luta do CEBES. São Paulo: Lemos Editorial; 1997. p.227-40.

Segre M. Definição de bioética e sua relação com a ética, deontologia e diceologia. In: Segre M, Cohen C (Org.) Bioética. São Paulo: Edusp; 1995. p. 23-30.

Sgreccia E. Manual de bioética: I - Fundamentos e ética biomédica. São Paulo: Loyola, 1996.

Silva FL. Da Ética Filosófica à Ética em Saúde, IN: Costa SIF, Garrafa V, Oselka G (Org.) Iniciação a Bioética. São Paulo: CFM; 1998. p.81-93.

Silva SR. Mais ética nas pesquisas. Rev Assoc Paul Cir Dent 2001; 55: 393403.

Spinetti SR. Análise ética em artigos científicos que envolvam seres humanos, no período de 1990 - 1996. [dissertação] São Paulo (SP): Faculdade de Saúde Pública da USP; 2001.

Sposati A. Conhecimento da verdade e o exercício do poder. IN: Sposati A (Org.) $O$ uno e o múltiplo nas relações entre as áreas do saber. São Paulo: Cortez; 1995. p. 66-82

Vieira S, Hossne WS. Pesquisa Médica: A ética e a metodologia. São Paulo: Pioneira; 1998.

Weil P. A nova ética. Rio de Janeiro: Ed. Rosa dos Tempos; 1993. 
Winspear WJ. Human experimentation in dental research. Aust. Dent. J. 1981; 26: 92-4.

Xavier ED. A bioética e o conceito de pessoa: a re-significação jurídica do ser enquanto pessoa. Bioética 2000; 8: 217-28.

Zoboli ELCP. O CEP, o pesquisador e o cultivo da tolerância. Cad Et Pesq CONEP 1999; 2:20-1. 
SUMMARY

\section{THE COMPREHENSION OF DENTAL RESEARCHERS ABOUT ETHICS IN RESEARCH INVOLVING IN}

\section{HUMAN BEINGS}

The look over human beings is primordial in the history of ethic analyzes on research. Some episodes of abuse with human being experiments around the world suggested more efficient organization of States and of the society in general towards the control and ethics orientations on researches; several authors associated these episodes with the origin of Bioethic. In Brazil, the reference of this reflection and orientation is based on the approval of the Resolution no. 196/96. Subsequently on Ethics in Research Committees (CEPs) have been installed and the research involving human beings has been intensely discussed and reflected on the institutional ambit. The present study identified and analyzed the Dental research's speech about ethic in research, he conceive the: involvement of the human beings in research and the use of questionnaires and/or interviews. We used the qualitative method and Content's Analysis as a mediator instruments to understand the speech. Twenty-eight researchers have been interviewed by following a list of questions that aided on the dialogue process between the interviewer and interviewed. Based on such 
analysis, it is considered that: 1 - In Dental research, the human beings involved are usually the patients attended by dental schools. These people are usually from a low social class and economical condition and lack education. 2 - A considerable social, professional, personnel gap between the researcher and the interviewed was identified. 3 - The researcher understands the Resolution $n^{\circ}$ 196/96 in different aspects: regulatory; educatory and restrictive. 4 - The knowledgement of such Brazilian rule is important to the assistant to the researcher in the analyze and behavior of his of research. $5-\mathrm{A}$ bilateral effort to develop a relationship is essential for a better mutual comprehension between the researcher and the CEP. 6 - The use of questionnaires and interviews is frequently considered a riskless method for the interviewed. The importance of physical and spiritual risk assessment is highlighted. $7-$ The ethic comprehension of research is determined by the social context that the researcher is involved in; his position towards ethic is associated to the comprehension that he/she has about the world, the society, the human being and moral values. 


\section{AUTORIZAÇÃO}

Autorizo a reprodução e/ou divulgação total ou parcial da presente obra, por qualquer meio convencional ou eletrônico, desde que citada a fonte e comunicada, a autora, a referência bibliográfica em que consta a citação.

Luciana Maria Cavalcante Melo

Assinatura

Universidade de São Paulo

Faculdade de Odontologia

Departamento de Odontologia Social

São Paulo, dezembro de 2002

Av. Prof. Lineu Prestes, 2227

Cidade Universitária - São Paulo - SP.

E-mail: lumelo@usp.br 